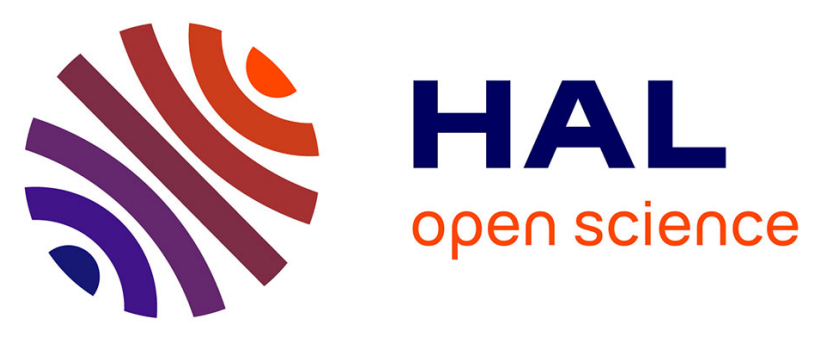

\title{
Changes in hydrodynamic process dominance (wave, tide or river) in foreland sequences: The subalpine Miocene Molasse revisited (France)
}

Amir Kalifi, Philippe Sorrel, Philippe-Hervé Leloup, Vincenzo Spina, Bastien Huet, Albert Galy, Jean-loup Rubino, Bernard Pittet

\section{To cite this version:}

Amir Kalifi, Philippe Sorrel, Philippe-Hervé Leloup, Vincenzo Spina, Bastien Huet, et al.. Changes in hydrodynamic process dominance (wave, tide or river) in foreland sequences: The subalpine Miocene Molasse revisited (France). Sedimentology, 2020, 67 (5), pp.2455-2501. 10.1111/sed.12708 . hal03080936

\section{HAL Id: hal-03080936 https://hal.science/hal-03080936}

Submitted on 17 Dec 2020

HAL is a multi-disciplinary open access archive for the deposit and dissemination of scientific research documents, whether they are published or not. The documents may come from teaching and research institutions in France or abroad, or from public or private research centers.
L'archive ouverte pluridisciplinaire HAL, est destinée au dépôt et à la diffusion de documents scientifiques de niveau recherche, publiés ou non, émanant des établissements d'enseignement et de recherche français ou étrangers, des laboratoires publics ou privés. 
MR. AMIR KALIFI (Orcid ID : 0000-0003-3041-1401)

Article type : Original Manuscript

Changes in hydrodynamic process dominance (wave, tide or river) in foreland sequences: The subalpine Miocene Molasse revisited (France)

KALIFI Amir*†, SORREL Philippe*, LELOUP Philippe-Hervé*, SPINA Vincenzo†, HUET Bastien $\dagger$, GALY Albert $\ddagger$, RUBINO Jean-Loup $\dagger$, PITTET Bernard*

*Université de Lyon, UCBL, ENSL, CNRS, LGL-TPE, 69622 Villeurbanne, France.

$\dagger$ Total SA, CSTJF, Avenue Larribeau, 64000 Pau, France.

†CRPG , 15 rue Notre Dames des Pauvres, 54500 Vandœuvre-lès-Nancy, France.

Contact: amir.kalifi@etu.univ-lyon1.fr

\section{Associate Editor - Adam McArthur}

Short Title - Evolution of process changes in foreland basins

\section{ABSTRACT}

This article has been accepted for publication and undergone full peer review but has not been through the copyediting, typesetting, pagination and proofreading process, which may lead to differences between this version and the Version of Record. Please cite this article as doi: $\underline{10.1111 / \text { SED } .12708}$

This article is protected by copyright. All rights reserved 
A comprehensive sedimentological study was undertaken in the Miocene of the subalpine massifs and southern Jura (France) with the aim to constrain the evolution of process changes in third-order sequences of peripheral foreland basins during the overfilled phase (i.e. sediment supply higher than accommodation space). Fieldwork analyses based on 35 sedimentological sections allowed the identification of four depositional models: wave dominated, mixed wave-tide, river to tide and river dominated. The sections were dated using chemostratigraphy (i.e. marine Strontium isotopic ratios), revealing three third-order sequences between the Upper Aquitanian and the Langhian. Chronostratigraphical and sedimentological results document prominent and recurrent changes in depositional models along third-order sequences: (i) in the earliest stage of the transgression, mixedenergy coastal environments influenced by the local coastal morphology prevailed (in palaeo-highs or incised valleys); (ii) during the course of the transgression, Gilbert delta deposits suggest a prominent steepening linked to a tectonic uplift in the proximal depozone (between the tectonically active frontal part of the orogenic wedge and the proximal foredeep). Instead, in the distal depozone (between the proximal foredeep and the proximal border of the flexural uplifted forebulge), deposits were characterized either by wave-dominated or mixed wave-tide environments and are likely eustaticallydriven; (iii) during the maximum flooding stage, water depth remained shallow below the stormweather wave base; and (iv) during the regression, the proximal depozone is characterized by the progradation of gravel-rich fan deltas. In the distal depozone, mixed wave-tide systems preceded the development of river to tidal depositional environments. These results were integrated and compared with facies models from other basin analogues worldwide. A model tackling the evolution of process changes within third-order sequences (of the overfilled phase) of foreland basins is proposed, thereby improving sequence stratigraphic predictions in foreland basins.

KEYWORDS Combined wave-flow ripples, depositional model, Miocene molasse, mixed-energy environments, peripheral foreland basins, sequence stratigraphy.

This article is protected by copyright. All rights reserved 


\section{INTRODUCTION}

Yoshida et al. (2007) have questioned the use of classic facies models for sequence stratigraphic correlations, especially for nearshore deposits that commonly assume constant process regime throughout a relative sea-level (RSL) cycle in response to changes in accommodation space and sediment supply. However, the dominant processes are function of multiple, interplaying factors that can change during a RSL cycle, gradually or abruptly (Ainsworth et al., 2008, 2011; Olariu, 2014; Rossi \& Steel, 2016; Rossi et al., 2017b). Among the main factors, changes of coastal morphology, which have a huge impact on hydrodynamics (i.e. coastal morphodynamics), changes of bathymetry, sediment supply (coevally to climatic variations) along with more local forcings (for example, sediment source, tectonic control and degree of bypass) can be involved.

This study focuses on a geological context that involves complex interactions between three hydrodynamic processes (i.e. river, tide or wave) recorded in the Miocene peripheral foreland basin molasse deposits of the subalpine massifs and southern Jura. Peripheral foreland basins are elongate and narrow [hundred(s) of kilometres large] sedimentary basins formed by the flexural subsidence in front of a rising chain (Dickinson, 1974; DeCelles \& Giles, 1996). When marine sedimentation takes place, this configuration is responsible for: (i) amplification of tidal currents due to restriction of cross-sectional area (Defant, 1961; Pugh, 1987; Besson et al., 2005; Reynaud et al., 2006, 2012, 2013; Longhitano et al., 2014; Rossi et al., 2017a); (ii) high amount of sediment supply through fluvial inputs because the seaway is bounded by a rising belt; and (iii) influence of waves when the fetch of the seaway is wide enough. Since the 1990s, modern mixed-energy coasts have been investigated and processes are better constrained (Short, 1991; Masselink \& Short, 1993; Li et al., 2000; Yang \& Chun, 2001; Anthony \& Orford, 2002; Yang et al., 2005; Masselink et al., 2006; Vaucher et al., 2018a; b). Ancient mixed-energy coastal environments are being increasingly documented in the literature (Vakarelov et al., 2012; Ahokas et al., 2014; Leva López et al., 2016; Rossi \& Steel, 2016; Vaucher et al., 2017; Peng et al., 2018; Zhang et al., 2019).

Peripheral foreland basins are, therefore, ideal natural laboratories for testing the controls of facies changes as conceptualized by Yoshida et al. (2007). The main focus of this paper is thus to constrain the evolution of process changes during RSL cycles within a peripheral foreland basin through the case study of the stratigraphically well-constrained Miocene succession in the subalpine massifs and

This article is protected by copyright. All rights reserved 
southern Jura (based on a new comprehensive set of Strontium dating). For this purpose, first, the sedimentary record is examined and it is shown that more than one depositional model is required to reconstruct the Miocene coastal palaeoenvironments of the studied area. Second, a tentative model is developed in order to disentangle the evolution of process changes within third-order sequences of the overfilled phase of foreland basins. Finally, these results are discussed and integrated with other peripheral foreland basins worldwide.

\section{GEOLOGICAL SETTING}

The western Alpine foreland basin corresponds to the peripheral foreland basin of the Cenozoic Alpine orogeny, which resulted from the closure of the Tethyan Ocean and the continental collision between the Eurasian and Adrian tectonic plates (Nicolas et al., 1990; Pfiffner et al., 1997). The study area is localized along the subalpine massifs (i.e. the Vercors, Chartreuse and Bauges massifs) and the southern Jura in France (Fig. 1A). In this sector, the Miocene 'molasse' deposits are preserved within the synclines and constitute the infill of piggy-back basins (Fig. 1B). These deposits generally lie disconformably on thick Mesozoic substratum, or conformably on Oligocene continental deposits (Gidon et al., 1978; Bass, 1991; Butler, 1992; Allen \& Bass, 1993).

This succession was deposited during the second shallowing-upward cycle of the western Alpine foreland basin overfilled phase (Sinclair \& Allen, 1992). In the study area, the initial flooding of this stage took place during the Burdigalian (Latreille, 1969; Berger, 1985, 1992; Rubino et al., 1990; Bass, 1991; Burbank et al., 1992; Allen \& Bass, 1993; Fig.1C). Locally, marine sediments are up to $1150 \mathrm{~m}$ thick (Bass, 1991; Allen \& Bass, 1993). The last marine deposits have been attributed to the Langhian, or possibly Serravalian (Rubino et al., 1990; Bass, 1991; Allen \& Bass, 1993). They have been interpreted as accumulating in a narrow seaway that connected the Mediterranean Sea (Fig.1A; ex-Tethys) to the south, to the North Alpine Foreland Basin (Fig.1A; ex-ParaTethys) to the north (Demarcq, 1962; Rubino et al., 1990; Bass, 1991; Allen \& Bass, 1993). Restricted to the southern Jura synclines, Blanc (1991) and Allen \& Bass (1993) identified mainly tide-dominated and few wave-dominated sedimentary environments. Based on well-studied Miocene successions of the Rhodano-Provencal Molassic Basin (Fig.1A), 10 third-order sequences from S0 (Aquitanian) to S9

This article is protected by copyright. All rights reserved 
(Late Tortonian-Early Messinian) were identified (Rubino et al., 1990; Besson et al., 2002, 2005). In the poorly deformed Bas-Dauphiné basin (Fig. 1B and C), Kwasniewski (2010) proposed a similar sequence-stratigraphic framework based on well-log data. In the present study area, only lithostratigraphical subdivisions have been documented (Giot, 1944; Pelin, 1965; Bocquet, 1966; Latreille, 1969; Lamiraux, 1977; Mortaz-Djalili, 1977; Mortaz-Djalili \& Perriaux, 1979; Nicolet, 1979; Mujito, 1981) mostly because the biostratigraphical age control was very poor.

\section{MATERIALS AND METHODS}

The accessible, well-outcropping sections were analysed. Thirty-five sections were described in detail (Fig. 1B). Five to $1050 \mathrm{~m}$ thick sections were logged at a decimetre to metre scale. The combined analysis of textural characteristics, clastic and biogenic components, bed thickness, organization and geometry, sedimentary structures and their size, and palaeocurrent measurements, allow the definition of 25 facies grouped into 11 facies associations (FA). Four facies are not included in the FA list because they cannot be categorized. The FA corresponds to sedimentary environments. The FA themselves were recognized as belonging to five depositional process types: wave-dominated (W), mixed wave-tide (WT), tide-dominated (T), mixed river-tide (RT) and river-dominated (R). These hydrodynamic settings are further interpreted in the frame of four depositional models corresponding to various coastal morphologies. Depositional sequences were identified based on the evolution of FA and stratigraphic surfaces.

Biostratigraphical data using calcareous nannofossils and foraminifera coupled with strontium (Sr) isotope dating (i.e. chemostratigraphy) were used to constrain the ages of the sedimentary sections. The $\mathrm{Sr}$ isotope ratios were measured on marine carbonate skeletons (oysters and pectens) at CRPG (Centre de Recherches Pétrographiques et Géochimiques) in Nancy. A thorough preliminary inspection of shells was conducted at TOTAL (CJTJF, Pau, France) using cathodoluminescence, in order to: (i) select shells yielding a pristine structure; and (ii) to avoid recrystallized structures stemming from diagenetic processes. Corresponding ages are derived from measured ${ }^{87} \mathrm{Sr} /{ }^{86} \mathrm{Sr}$ ratio using the LOWESS non-parametric regression curve of McArthur et al. (2012). The uncertainties on

This article is protected by copyright. All rights reserved 
the numerical ages correspond to the uncertainty of measurements added to the uncertainty on the ${ }^{87} \mathrm{Sr} /{ }^{86} \mathrm{Sr}$ marine curve.

\section{SEDIMENTARY FACIES AND PALAEOENVIRONMENTS}

In this chapter, the five depositional process types are described through the associated FAs. The FAs are interpreted as sedimentary environments based on the facies description (lithology, bedding and key sedimentary structures; see Table 1 for details) and interpretations.

\section{Wave-dominated sedimentary environments}

Four facies associations correspond to wave-dominated sedimentary environments as defined in Reading (1996).

\section{Facies Association 1 - Offshore}

This FA consists of two main facies (F1 and F2; Table 1). Facies F1 is formed of massive units of marls and silts. F1 locally displays pluri-millimetre to centimetre-thick sandy normally-graded layers without any evidence of oscillation structures. Planktonic foraminifera have been found within this facies (Bizon \& Bizon, 1972; Lamiraux, 1977; Table 1). Facies F2 is composed of massive silts to very fine sands that are highly bioturbated. Occurrences of laterally continuous accumulations of decimetre-sized monospecific bivalves (pectens or elongate and massive oysters, Fig. 2A) (and planktonic foraminiferans (Latreille, 1969; Table 1) are also found.

Fine-grained sedimentation in F1 and F2 suggest a low-energy depositional environment. The presence of planktonic foraminifera indicates an open-marine environment. Facies FA1 is thus attributed to an offshore sedimentary environment. Sandy normally-graded layers without oscillation structure in F1 are interpreted as distal tempestites. The occurrence of laterally continuous accumulation of intact monospecific decimetre-sized bivalves in F2 suggests either: (i) reduced accumulation rates in the distal quiet-water offshore environment (more likely for pectens which are found at shallow to moderate water depths; Duncan \& Wilson, 2012); (ii) distal storm accumulation (more likely for oysters which are found at water depths less than 50m); or (iii) thanatocoenosis.

This article is protected by copyright. All rights reserved 


\section{Facies Association 2 - Offshore transition}

This FA consists of one facies (F3; Table 1). Facies F3 is formed of pluri-decimetre thick, fine sandy levels that are laterally discontinuous at a scale of metres to tens of metres, and are interstratified with silts to very fine sands (Fig. 2B). The sandy levels display decimetre-scale wavelength hummocky cross-stratification (HCS).

Facies Association 2 is interpreted as belonging to the offshore transition zone, between the stormweather wave base (SWWB) and the fair-weather wave base (FWWB). In F3, alternations between fine-grained deposits with sandy layers exhibiting HCS suggest storm influence in a generally quiet environment.

\section{Facies Association 3 - Shoreface}

This FA includes only one facies (F4; Table 1). Facies F4 consists of medium to very coarse-grained calcarenites (Fig. 2C and D), which exhibit amalgamated oscillation structures (HCS and wave ripples). Facies F4 contains a variable proportion and type of bioclasts (Fig. 2D; Table 1).

Facies Association 3 is interpreted as corresponding to a shoreface sedimentary environment. In F4, the stacking of successive layers with oscillations structures suggests a continuous high-energy, wavedominated coastal environment located above the FWWB. The faunal assemblage is similar to the Miocene deposits in the Saumane-Venasque area located $150 \mathrm{~km}$ southward (Reynaud et al., 2006, 2012; Reynaud \& James, 2012; James et al., 2014), which is attributed to a warm-temperate marine environment (i.e. Foramol association).

\section{Facies Association 4 - Foreshore}

This FA consists of two facies (F5 and F6; Table 1). Facies F5 is composed of massive units with very well-sorted, medium to very coarse sandstones displaying plane-parallel to low-angle parallel stratifications (Fig. 3A, C, H and I) showing clinoform geometries (see onlaps and oblique tangential downlaps; Fig. 3F and G). Locally, antidunes (Fig. 3E), root traces below one well-marked surface (Fig. 3G) and round-shaped, centimetre-scaled aligned mud-clasts can be observed. Small-scale oblique tangential cross-strata, showing downcutting in their bottomsets, are also observed (Fig. 3J).

This article is protected by copyright. All rights reserved 
Facies F6 corresponds to clast-supported micro-conglomerates to conglomerates. The pebbles and cobbles are well-rounded, poorly sorted and locally bioperforated and imbricated (Fig. 3B and D). Facies F6 displays oblique tangential stratification corresponding to clinoform bottomsets (Fig. 3D). Facies Association 4 is interpreted as being deposited in the foreshore to backshore sedimentary environment (beach). Plane to low-angle parallel stratifications in F5 imply high-energy wave currents (foreshore). Onlapping planar laminated sandstones correspond to retrograding beach clinoforms, and oblique tangential stratifications correspond to prograding clinoforms. Root traces suggest the onset of vegetation in the backshore. Imbrications and bioperforation in F6 indicate storm beach berms deposits. In F5, small-scale dunes with downcutting in the bottomsets suggest that they are formed by wave action under an indirect influence of tides (Vaucher et al., 2018a). This interpretation is reinforced by the local presence of mud-clasts (rare in pure wave-dominated systems; Dunbar \& Rodgers, 1957). In this context, antidunes might be explained by the swash and backwash currents interferences during rising or falling tides (Vaucher et al., 2018a).

\section{Mixed Wave-Tide sedimentary environments}

\section{Facies Association 5 - Open-coast subtidal}

This FA consists of two facies (F7, F8; Table 1). The FA5 deposits are stratigraphically encountered above or interstratified with FA1 (and FA2) offshore deposits (Fig. 4A and B). Facies F7 and F8 are heterolithic facies having different mud/sand ratios: F7 is dominated by muddy sediments that contain lenses of sand ('lenticular bedding'; Fig. 4C to F), whereas F8 displays alternations of sandy and muddy layers that are wavy, centimetre to decimetre thick and laterally either continuous or discontinuous at metres to tens of metre-scale ('wavy bedding'; Fig. 4G and H). In F7 and F8, the muddy levels immediately overlying sandy levels or lenses, correspond to 'fluid mud' deposits (Traykovski et al., 2000; Dalrymple et al., 2003; McAnally et al., 2007; Ichaso \& Dalrymple, 2009). The sands are well-sorted with a fine to medium grain size and display symmetrical to slightly asymmetrical ripples (rarely bi-directional) interpreted as combined wave-flow ripples. Increase of the leeward slope angularity and occurrence of downcutting in the bottomsets are observed (Fig. 4E, F and $\mathrm{H}$ ). Foreset laminae are often draped of mud deposits with a repetitive variability in the intensity

This article is protected by copyright. All rights reserved 
of mud deposits (Fig. 4F). The relative mud/sand ratio repetitively varies vertically in both F7 and F8. Facies F7 and F8 are rarely bioturbated.

Facies Association 5 is interpreted as belonging to an open-coast subtidal sedimentary environment, between the SWWB and the intertidal zone. The F7 and F8 heterolithic facies suggest alternations of quiet-water deposits and combined wave-flow ripples. The occurrence of oscillation structures suggests a marine environment dominated by waves or storms. The presence of foreset laminae that are draped by mud deposits, possibly indicate a secondary influence by tides. The discontinuous pattern of deposition of the sandy levels corresponds to one characteristic of tide-modulated, wavedominated sedimentary environments (Vaucher et al., 2017). The increase of the leeward slope angularity and the occurrence of downcutting in the bottomsets are absent in pure current ripples, since these sedimentary structures (for example, slope progradation) are in equilibrium with the unidirectional current that generates them (Vaucher et al., 2018a). These criteria suggest that the size of wave orbitals impacting on the sediment floor were modified by changes in sea level during tidal cycles.

Hence, FA5 most likely infers an open-coast environment modulated by tidal cycles. According to the $\mathrm{mud} / \mathrm{sand}$ ratio, F7 is the deepest facies and F8 the shallowest.

\section{Facies Association 6-Open-coast intertidal}

This FA includes two facies (F9 and F10; Table 1). Facies F9 consists of massive and laterally continuous very well-sorted, fine to medium sandstones (Fig. 5A) displaying flaser bedding (Fig. 5B). Facies F9 is stratigraphically encountered above F7 or F8 with a sharp contact, sometimes underlined by decimetric gutter casts (Fig. 5C). Facies F10 consists of an alternation of laterally discontinuous very well-sorted, fine to medium sandstones at a scale of tens of metres and of fine-grained heterolithics (silts to very fine sands; Fig. 5D). Sandstones display symmetrical to slightly asymmetrical ripples (Fig. 5E) or SCS and HCS structures that repetitively pass vertically to planeparallel laminations. Sandstones evolve laterally to fine-grained sediments, leading to a heterolithic facies with symmetrical to slightly asymmetrical ripples interpreted as combined wave-flow ripples. They commonly display oblique foresets with downcutting in their bottomsets (Fig. 5F).

This article is protected by copyright. All rights reserved 
Facies Association 6 is interpreted as belonging to an open-coast intertidal sedimentary environment. In F9, the lack of structures and geometries makes this interpretation somewhat speculative. However, the systematic stratigraphic occurrence of F9 above or interstratified with the open-coast subtidal deposits (FA5) suggests a similar mixed-energy sedimentary environment. It is in accordance with the gutter casts suggesting storm influences. In F10, the lateral changes from sandstone levels displaying planar stratifications and SCS to heterolithic facies displaying wave structures (combined wave-flow ripples) suggest a 'ridge and runnel' environment (Vaucher et al., 2017, 2018b). This type of organization develops in tide-modulated, wave-dominated coast (Short, 1991; Kroon \& Masselink, 2002; Anthony et al., 2004; Masselink et al., 2006; Reichmüth \& Anthony, 2007; Vaucher et al., 2017, 2018a; b), where the intertidal zone consists of topographical highs (ridges) and lows (runnels). The ridges are formed by the swash and backwash during rising and falling tides. The runnels are filled during high tides with a dominant wave action, thus explaining the dominance of wave sedimentary structures interstratified with fine-grained heterolithics deposited at low tides. Moreover, changes in sea level during tidal cycles modify the size of wave orbitals impacting on the sediment floor as testified to by the frequent occurrence of downcutting in the bottomsets of the ripples (Vaucher et al., 2018a; b).

\section{Tide-dominated sedimentary environments}

\section{Facies Association 7 - Subtidal}

This FA consists of four facies (F11, F12, F13 and F14; Table 1). Facies F11, F12 and F13 are made of fine to very coarse, well to poorly sorted sandstones, sometimes bioclastic sandstones or calcarenites. These facies display oblique tangential stratifications (Fig. $6 \mathrm{~A}$ to $\mathrm{C} ; 1$ to $5 \mathrm{~m}$ ) that orthogonally correspond to large-scale trough cross-beds (Fig. 6D; 5 to 10m). The size of the crossbeds decreases from F11 to F13. Fine-grained levels commonly occur in the bottomsets as flaser to wavy bedding (Fig. 6E). A repetitive variability in the thickness of cross-laminae (Fig. 6B) and metrescale sigmoid-shaped cross-strata are observed (Fig. 6F). Facies F11 is laterally discontinuous at tens to hundreds of metres and often pass laterally to fine-grained deposits. Facies F12 is found as massive units of stacked cross-bedding (Fig. 6C and F). Facies F13 is laterally discontinuous at metre to tens

This article is protected by copyright. All rights reserved 
of metres and displays muddy or organic matter-rich single or double drapes in the bottomsets of the cross-beds. Discontinuous conglomeratic levels locally underline the cross-stratifications (Fig. 6G and H). Facies F14 consists of sandy (coarse to very coarse poorly-sorted) or heterolithic (flaser to wavy bedding) deposits filling 5 to $15 \mathrm{~m}$ deep incisions that are laterally discontinuous at tens to hundreds of metres. Sandstones display decimetre to metre-scale cross-beds with flaser beddings that are organized along very large-scale low-angle inclined surfaces (tens of metres wide; Fig. 6I and J). Locally, tangential stratifications are observed in opposite directions. Heterolithic flat-lying channel infill is separated by erosive low-angle large-scale inclined surfaces that are frequently covered by bioclasts, pebbles and mud clasts (Fig. 6K to M). Heterolithics consist of pluri decimetre-thick alternations of flaser to wavy bedding levels containing bi-directional ripples and load casts (Fig. 6M and $\mathrm{N})$.

Facies F11, F12 and F13 are interpreted as metre-scale tidal dunes. The occurrence of fine-grained deposits in the bottomsets of the dunes, the repetitive variability in the thickness of the crossstratifications, and the local presence of sigmoidal stratifications corresponding to tidal bundles, reflect tidal cycles (Boersma, 1969; Visser, 1980; Yang \& Nio, 1985; Kreiza \& Moila, 1986; Ashley, 1990). Facies F14 is interpreted as tidal channel infills. Flaser/wavy bedding and bidirectional tangential structures testify to tidal influence. The low-angle infilling oblique organization is interpreted as resulting from lateral accretion in meandering tidal channels (Thomas et al., 1987; Pelletier, 2012).

The pluri-metric tidal dunes and the channels depth suggest that F11 to F14 were deposited in subtidal sedimentary environments (water depth $<25 \mathrm{~m}$; Dalrymple \& Rhodes, 1995). Facies F11 interstratified with offshore deposits (FA1) is interpreted as a deep subtidal zone. In F13, well-marked flasers containing organic matter, smaller metric cross-beds and discontinuous conglomeratic levels suggesting fluvial influences, likely correspond to the shallowest subtidal zone.

\section{Facies Association 8 - Intertidal}

This FA consists of three main facies (F15, F16 and F17; Table 1). Facies F15 is mainly composed of massive medium to coarse well-sorted sandstones. Sandstones displays pluri-decimetre to metre-scale tangential cross-beds (Fig. 7A) that orthogonally correspond to pluri-metre trough cross-beds.

This article is protected by copyright. All rights reserved 
Symmetrical to asymmetrical ripples draped by thin mud or silts are observed in the bottomsets (Fig. 7B). Opposite-directed ripples are locally observed. Facies F16 is composed of heterolithic deposits (wavy to lenticular bedding) displaying bi-directional asymmetrical ripples (Fig. 7C), rill marks (Fig. 7D) and loadcasts (Fig. 7E). Facies F17 is mainly composed of fine to medium well-sorted sandstones, locally with abundant mudclasts, filling 1 to $5 \mathrm{~m}$ deep incisions (Fig. 7F to H).

Facies Association 8 is interpreted as belonging to the intertidal zone. As in FA7, F15 and F16 display current structures such as dunes (F15), current ripples (F16) and quiet-water deposits. Bi-directional currents suggest tidal dominance. In F15, symmetrical to asymmetrical ripples in the bottomsets of the dunes correspond to run-off currents localized in the inter-dune trough and orientated orthogonally to the tidal currents (Homewood, 1981; Fenies \& Faugères, 1998). In such a sandy dominated facies, this criteria suggest intertidal deposits because run-off implies episodic subaerial exposure at low tide (Fenies et al.; 1999). Facies F16 displays small-scale rill marks also suggesting run-off during falling tide. The sand-dominated F15 deposits correspond to the sandflat, whereas the heterolithic F16 deposits correspond to the mixed-flat (Reineck \& Wunderlich, 1968). Facies F16 is thus more proximal than F15. Facies F17 that fills incisions is observed interstratified within F15 or F16. Facies F17 then corresponds to tidal creeks that drain water and sediment from the supratidal to the subtidal zone.

\section{Mixed River-Tide sedimentary environments}

\section{Facies Association 9 - River to tidal transition}

This FA consists of one facies only (F18; Table 1). Facies F18 is composed of a thick accumulation of flat-lying, moderately sorted, medium to coarse-grained sandstones containing levels rich in pebbles and cobbles that are clast-supported, poorly sorted, well-rounded and locally imbricated. Two main palaeo-current directions are observed in F18. Predominant north and/or southward-directed palaeocurrents were measured exclusively in sandstones displaying pluri-decimetre oblique tangential crossbeds (i.e. dunes; Fig. 8A to D). In contrast, westward-directed palaeo-currents were measured, both in

This article is protected by copyright. All rights reserved 
sandstones displaying pluri-metric to decametric trough cross-beds (Fig. 8A to E) and in conglomerates, with local erosion surfaces forming gutter-like channels less than $3 \mathrm{~m}$ deep and a few metres wide (Fig. 8A, B, E and F). A few channels exhibit a typical lateral accretion and polyphasic infill. Bidirectional ripples and fine-grained deposits (for example, clays) containing wood fragments in the bottomsets of dunes (Fig. 8D) are also commonly observed. Conglomerates are also found as sheet-like, laterally continuous, levels (Fig. 8B and E), or underlining trough cross-beds (Fig. 8F and G). Abundant centimetric angular mud clasts form levels that are locally interstratified within the sandstones (Fig. 8H).

Facies F18 massive flat-lying sandstones displaying dunes suggest a wide area characterized by a flat gradient slope. The dominant north-south palaeo-currents measured on dunes argue for a seawardaxis directed palaeo-currents (because the shoreline was north-south directed) most likely corresponding to tidal currents, which is in accordance with the occurrence of bidirectional ripples (and clays in the bottomsets of dunes). The interstratification of conglomeratic levels, the westwarddirected palaeo-currents inferred from the sandy trough cross-beds and the erosional gutter-like channels both imply a riverine influence. In this context, fine-grained deposits containing wood fragments in the bottomsets of tidal dunes, sheet-like laterally continuous conglomeratic levels and mud clasts suggest that the material brought by the river was probably reworked by tides. Facies Association 9 is interpreted as belonging to a 'river to tidal' transitional zone.

\section{River-dominated sedimentary environments}

\section{Facies Association 10 - River environment}

This FA consists of two facies (F19 and F22; Table 1). Facies F19 is formed of massive clastsupported conglomerates displaying low-angle, sub-planar, pluri-metre trough cross-beds (Fig. 9A and B). The pebbles, cobbles and boulders are moderately sorted, well-rounded, and frequently imbricated (Fig. 9C and D). The conglomeratic unit is formed of a stack of pluri-decimetre to metrescale sheet levels of various grain sizes (Fig. 9C and D). Normally-graded levels (Fig. 9C) and interstratification of laterally discontinuous mud deposits rich in lignite containing micro-mammals (Clauzon, 1990) were observed. When F19 covers F18 river to tide transitional deposits, the base of 
the unit displays pluri-metric deep incisions, filled by obliquely stratified conglomerates (Fig. 8F, 8G and 9A). Facies F22 is composed of reddish muddy to sandy levels (Fig. 9C and E; Table 1), laterally discontinuous at a metre to tens of metre-scale. Few rootlets were observed.

Facies F19 concurs with a braided-river system. The frequently imbricated clast-supported conglomerates, the sub-horizontal strata made of a stack of sheet levels and low-angle pluri-metre trough cross-beds suggest the progradation of braided fluvial bars during floods. The occurrence of

very poorly sorted levels containing boulders suggests a proximity to mountains. Facies F22 reddish sandy levels containing rootlets suggest subaerial exposure in palaeosoils. Facies F22 and discontinuous continental mud deposits (lignite and micro-mammals) interstratification within F19, indicate abandonment areas. Deep erosional surfaces at the base of braided-river deposits are interpreted as channels. Facies Association 10 is thus attributed to a river-dominated deltaic to continental depositional environment.

\section{Facies Association 11 - Gilbert delta}

This FA consists of four facies (F19 to F22; Table 1). Facies F20 is formed of coarse sandy matrixsupported conglomerates that form thick massive units. The pebbles and cobbles are poorly sorted, well-rounded, and rarely bio-perforated. Facies F20 displays 15 to $30 \mathrm{~m}$ high tangential cross-beds dipping at 20 to $30^{\circ}$ (Fig. 10A to C). Facies F19 flat-lying conglomerates (described earlier) is always found on top of F20 (Fig. 10B and C). Facies F21 is formed of 10 to $15 \mathrm{~cm}$ thick levels of pebbles interstratified in muddy deposits (F1 and FA1; Fig. 10D).

Facies Association 11 corresponds with a Gilbert delta (Gilbert, 1885) system. Poorly sorted, matrixsupported conglomerates of F20 likely correspond to debris-flow deposits. Well-rounded pebbles to cobbles and the occurrence of exotic clasts suggest a rather long-distance transport by a fluvial system. The decametric high, oblique tangential foresets implies the progradation of a large sedimentary body interpreted as a river-dominated, Gilbert delta. The F19 braided-river system (FA10) always covers F20, which further argues for the progradation of the delta plain (delta topsets; Gobo, 2014). Interstratified conglomeratic levels within the offshore FA1 deposits (for example, F21) are interpreted as the bottomsets of a Gilbert delta.

This article is protected by copyright. All rights reserved 


\section{Subaerial exposure}

Facies F22 is composed of reddish muddy to sandy levels (Fig. 9C and E). Facies F23 consists of a calcareous level. It displays an irregular surface at its top and tubular vertical structures in the level itself. This facies laterally pass to light grey marls that contain a freshwater fauna (Jodot, 1955; Berger, 1985).

Both F22 and F23 correspond to facies of subaerial exposure. F22 correspond to palaeosoils. Facies F23 is interpreted as calcretes formed during subaerial exposure of palustrine to lacustrine deposits (Rossi et al., 2020).

\section{Non-categorized facies}

Facies F24 is generally formed of matrix-supported conglomerates that form thin (decimetre to plurimetre) laterally discontinuous units at hundreds of metres to kilometre-scale. The pebbles, cobbles and some boulders are poorly sorted, moderate to poorly rounded, and can be imbricated. Facies F24 characterizes the basal Miocene marine sediments. Facies F25 consists of tilted or disturbed autochthonous centimetre to pluri metre-thick sedimentary successions. 'Ball and pillow' structures are commonly found. This facies is laterally continuous at tens of kilometre-scale. The organization of the clasts is chaotic (Fig. 10E).

Facies F24 conglomerates are interpreted as transgressive lag deposits. Poorly sorted clasts correspond to local material reworked during the transgression. Facies F25 corresponds to earthquake-disturbed layers (i.e. seismites). Disorganized monogenic clasts of various sizes and the lateral continuity at the basin scale indicate strong disturbance events.

\section{SEQUENCE STRATIGRAPHY}

Based on the vertical succession of the depositional environments, which rely on facies association interpretations, transgressive and regressive trends can be identified. Changes of relative sea level (RSL) can be reconstructed for each logged section (for example, Fig. 11, rightmost column of each log). Hence genetic sequences sensu Homewood et al. (1992) can be identified. Two orders of sequences could be deciphered in some sections. The ${ }^{87} \mathrm{Sr} /{ }^{86} \mathrm{Sr}$ ages (yellow boxes in Fig. 11; Table 2)

This article is protected by copyright. All rights reserved 
allowed the calibration of the average time span for each sequence. Large-scale sequences have a mean duration $>1.5 \mathrm{Myr}$ and can be attributed to third-order sequences sensu Vail et al. (1991). Alternatively, the small-scale sequences likely span less than $0.5 \mathrm{Myr}$, and therefore correspond either to fourth or fifth-order sequences.

Based on the Sr dating and few available biostratigraphic data, correlations are then possible between all of the studied sections (Table 2; Fig. 12). Three third-order sequences were identified. They likely correspond to S1, S2 and S3 belonging to the Miocene megasequence of the western Alpine foreland basin defined by Rubino et al. (1990). These sequences are possibly eustatic in origin (Miller et al. (2005); Fig. 12).

(i) The base of S1 ranges between 21.8 Ma and 20.75 Ma (Late Aquitanian, Fig. 12). This time interval was determined by using the four oldest ${ }^{87} \mathrm{Sr} /{ }^{86} \mathrm{Sr}$ ages available because the initial transgression took place on an irregular palaeo-landscape (Bass, 1991; Allen \& Bass, 1993; also detailed later) that implies an important diachronism of the first marine deposits from one section to the other. Sequence S1 was likely eustatically-driven according to the Late Aquitanian eustatic sea-level rise reported by Miller et al. (2005) between 21.05 and 20.6 Ma (Fig. 12).

(ii) The base of S2 is dated between $18.7 \mathrm{Ma}$ and $18.15 \mathrm{Ma}$ (Burdigalian; Fig. 12). Sequence S2 was likely eustatically-driven according to the Late Burdigalian eustatic sea-level rise between 17.83 Ma and 17.63 Ma (Miller et al. 2005; Fig.12).

(iii) The age for the base of S3 ranges between 16.85 Ma and 16.45 Ma (Late Burdigalian Early Langhian; Fig. 12). This age is older than the Late Burdigalian/Early Langhian eustatic sea-level rise dated between 16.27 and 15.59 Ma (Miller et al. 2005; Fig. 12).

\section{DEPOSITIONAL MODELS}

Mixed sedimentary environments are the most common in the Miocene molasses (Fig. 11; reading guideline in Fig.11A; log numbers 4, 5, 13, 16 and 22 presented in Fig. 11B to F; locations in Fig.1) and are either mixed wave-tide (WT) or mixed river-tide (RT). Wave-dominated (W), tide-dominated

This article is protected by copyright. All rights reserved 
(T) and river-dominated (R) sedimentary environments are less common. Based on the facies assemblages and their spatial distribution along proximal to distal transects (applying the Walther's law; Walther, 1894), four distinct depositional models were highlighted (Fig. 13).

\section{Wave-dominated depositional model}

The Loisieux section (0 to $115 \mathrm{~m}$; Fig. 11B) shows from the bottom to the top: (i) shoreface deposits (FA3, Fig. 2C); (ii) progressively passing to offshore transition deposits (FA2, Fig. 2B); and (iii) offshore deposits (FA1, Fig. 2A). In addition, the Corbel panorama (Fig. 3) shows coarse-grained amalgamated oscillation structures (F4, FA3 and shoreface) and planar laminated sandstones (F5, FA4 and foreshore) onlapping on gravelly beach berms (F6, FA4 and foreshore). Facies Associations 1 to 4 thus belong to a wave-dominated coast depositional model ranging from the offshore to the foreshore likely corresponding to a reflective shoreline (Wright et al., 1979, 1984; Short, 1984; in Reading, 1996). This shoreline type is characterized by a steep foreshore profile that passes into a gently inclined shoreface towards the basin (Fig. 13A). At Corbel (locality '7', Fig. 1), the occurrence of downcutting in the bottomsets of beach clinoforms, along with the presence of mud clasts, wave megaripples and antidunes (Fig. 3) within planar laminated sandstones suggest a secondary influence and modulation by tides.

\section{Mixed Wave-Tide depositional model}

Numerous log sections (for example, Loisieux section, 53 to $140 \mathrm{~m}, 300$ to $487 \mathrm{~m}$; Chailles Est section, 20 to $120 \mathrm{~m}$; Grésy section, 443 to $620 \mathrm{~m}, 897$ to $975 \mathrm{~m}$; Forezan section, 473 to $625 \mathrm{~m}, 710$ to $860 \mathrm{~m}$; Fig. 11B, C, D and F) show the following vertical succession: (i) offshore deposits (FA1, Fig. 2); (ii) open-coast subtidal deposits (FA5, Fig.4); and (iii) above a sharp transition, open-coast intertidal deposits (FA6, Fig.5). Facies Associations 1, 5 and 6 thus co-exist in one mixed-energy depositional model (wave-dominated, tide-modulated) ranging from the offshore to the open-coast intertidal (Fig. 13B).

Large to medium-scale tidal dunes (1 to $5 \mathrm{~m}$, FA7, Fig.6) were found interstratified in offshore deposits (Fig. 6B), as well as in open-coast subtidal deposits (FA5; for example, Loisieux section, 270 to $310 \mathrm{~m}$; Grésy section, 620 to $728 \mathrm{~m}$; Forezan section, 620 to $705 \mathrm{~m}$; Fig. 11B, D and F). Palaeo- 
directions mainly follow the main seaway axis (north-south, Fig. 6A). This suggests the presence of longshore tidal currents, as reported from the actual English Channel (Berne et al., 1988; Ferret, 2011).

The succession from offshore to open-coast intertidal deposits suggests a coastal progradation. It could correspond to a deltaic or a macro-tidal beach progradation. In open-coast subtidal deposits (FA5, Fig. 4), fluid-muds immediately overlying combined-flow ripples suggest a wave or tidal resuspension of previously deposited mud that indicates a delta front area (Dalrymple et al., 2003; Ichaso \& Dalrymple, 2009).

In the modern mixed-energy coasts of Queensland (Australia), Short (1991) proposed three groups of macro-tidal beaches showing the evolution between wave and tide end-members. From Group 1 to Group 3, the slope gradient and wave intensity decrease. Group 1 is structureless, as in F9 (Fig. 5A to C). The structures are erased by wave and swash processes that four times daily swept the area (tidal cycles; Short, 1991). Group 2 is characterized by a topography formed of ridges and runnels, as in F10 (Fig. 5D to F). They are typical from fetch-limited seas with high tides (King, 1972; Short, 1991). This is in agreement with the studied peripheral foreland basin context.

Located stratigraphically above the mixed influenced open-coast intertidal deposits, tidal dunes (FA7, Fig. 6) or tidal flats deposits (FA8, Fig. 7) are encountered in the Subalpine Molasses deposits (for example, Loisieux section, 130 to 208 m; Chailles Est, 120 to 140 m; Grésy section, interval between 105 to 182 m, 950 to 1010 m; La Roize section, 5 to 28 m; Forezan section, 925 to 983 m; Fig. 11B to F). This transition marks the disappearance of wave influence and the flattening of the slope gradient that require another depositional model.

\section{River to Tide depositional model}

When tidal flats are encountered, logged sections show the following vertical succession: (i) subtidal deposits (FA7, Fig. 6); (ii) intertidal deposits (FA8, Fig. 7); (iii-a) an erosive surface at top of FA8 deposits (for example, Loisieux section, 165 to 208 m; Grésy section, 803 to 870 m; La Roize section, 19 to $28 \mathrm{~m}$; Fig.11B, D and E); (iii-b) a progressive downward shift with river-mouths deposits (FA9, Fig. 8; for example, Loisieux section 575 to $630 \mathrm{~m}$; Forezan section, 955 to $1030 \mathrm{~m}$; Fig. 11B and F) and then braided-river system deposits (FA10, Fig. 9; La Roize section, 60 to 192 m; Fig. 11E); and

This article is protected by copyright. All rights reserved 
(iii-c) a brutal downward shift with an erosive surface and braided-river system deposits (FA10, Fig. 9; for example, Grésy section, 978 to 1055 m; Fig. 11D). Facies Association 7, 8, 9 and 10 thus cooccur in one river to tide-dominated depositional model ranging from subtidal to continental subenvironments (Fig. 13C). Only in the last case (iii-c), FA10 are deposits likely to correspond to discordant deposits. In such a case, the basin physiography must have changed in the meantime, making the co-occurrence in the same depositional model hazardous.

Tidal flats depositional environments imply a flat slope configuration. Therefore, such a transition from tidal flats to braided-river systems involves an increase of the slope upstream from the shoreline. It agrees with gravel-rich fan-deltas bordered by an adjacent highland (Surlyk, 1984; McPherson et al., 1987).

\section{River-dominated Gilbert-delta depositional model}

The La Roize section (190 to 300 m; Fig. 11E) shows from the bottom to the top: (i) Gilbert delta deposits (FA11, Fig. 10); and (ii) braided-river system deposits (FA10, Fig. 9). Facies Associations 11 and 10 thus co-occur in a river-dominated Gilbert delta depositional model (Fig. 13D).

Hydrodynamic processes are river-dominated. Gilbert deltas involve an average foreset slope of about 25 to $35^{\circ}$ (Postma \& Roep, 1985; Wescott \& Ethridge, 1990). The organisation of the fluvial sheet conglomerates of FA10 (Fig. 9) indicates that the proximal area is characterized by a relatively flat gradient slope, corresponding to the Gilbert delta topsets (Fig.10). It is in agreement with the interstratification of pluri-metre lignite lenses corresponding to abandoned area on a subaerial deltaic fan position. In absence of meandering transitional deposits, FA10 corresponds to a gravel-rich fandelta bordered by an adjacent highland (Surlyk, 1984; McPherson et al., 1987).

\section{Palaeo-landscape during the initial transgression}

The topography of the palaeolandscape invaded during the transgression can strongly influence hydrodynamic and sedimentary processes (Belknap \& Kraft, 1985; Malikides et al., 1988; Frouin et al., 2007; Reynaud \& James, 2012; Reynaud et al., 2012; Tessier et al., 2012; Longhitano, 2013). The

This article is protected by copyright. All rights reserved 
subcrop map of the formations below the first Miocene marine deposits in Fig. 14 allows the reconstruction of the foreland basin configuration prior to the Miocene transgression.

In the study area, the substratum on which the initial Miocene transgression took place was subhorizontal because no angular unconformities were observed. However, Miocene marine deposits overlie a wide variety of stratigraphic formations (Fig. 14A and B): conformably on Oligocene continental deposits but disconformably on erosional surfaces from the Upper Cretaceous to the Upper Jurassic. This implies the existence of topographical highs (reliefs) and lows (valleys). The close-up view in Fig. 14B highlights: (i) east-west local deep incisions (Fig. 14B to D); and (ii) a dip of $c a 1^{\circ}$ only would explain the differential erosion (about 300 to $400 \mathrm{~m}$ ) of the Mesozoic strata (Fig. 14B and C) and the eastward progressive thickness increase of the Oligocene lacustrine or alluvial plain deposits.

As shown in Fig. 14, the palaeolandscape on which the first Miocene marine transgression occurred had an irregular and complex topography. To the west, the substratum was rocky with palaeo-highs and east-west incised valleys, probably in response to the north-south forebulge uplift. To the east, the substratum corresponded to a flat topography created by Oligocene lacustrine sediments deposited in response to flexural subsidence in the foredeep.

\section{DISCUSSION}

\section{Foreland basin zonation}

The subsiding peripheral foreland basin system is located between the orogenic wedge and the adjacent craton (Dickinson, 1974; DeCelles \& Giles, 1996). For this study, the foreland basin system zonation of DeCelles \& Giles (1996) has been subdivided into two depozones (Fig. 15): the proximal depozone (including the wedge-top and the proximal foredeep); and the distal depozone (the proximal forebulge border and the distal foredeep). In peripheral foreland basins types (Fig. 15), according to Decelles (2012), the forebulge and backbulge depozones are non-preserved because the rigid lithosphere implies a reduced or even absence of far-field dynamic loading.

Subsidence, internal architecture and accommodation patterns are different in each depozone (DeCelles \& Giles, 1996). Hence, at the basin scale, the sedimentary records are different. In the 
proximal depozone, the slope gradient, the tectonic activity and the sediment input from the adjacent orogenic wedge are more important than in the distal depozone.

\section{The distal to proximal depozone transition}

Foreland basin vertical sedimentary succession correspond to a transition from distal depozone to proximal depozone deposits, reflecting the progressive advance of the orogenic wedge towards the foreland basin. Along this sedimentary succession, an acceleration of subsidence is also recorded due to the migrating depocentre located in front of the adjacent thrust belt (DeCelles \& Giles, 1996; Decelles, 2012). Thus, the transition from distal depozone deposits to proximal depozone deposits is associated with: (i) coarse-grained sedimentation due to the proximity to the orogeny; (ii) growth strata; and (iii) abnormally thick accumulation of sediments.

In this study, the sections show a shallowing upward succession through marine successions capped by gravel-rich fan delta deposits at the top of the sections ( 600 to $630 \mathrm{~m}$ of Loisieux section; 1015 to $1055 \mathrm{~m}$ of Grésy section; 985 to $1030 \mathrm{~m}$ of Forezan section; Fig. 11B, D and F). This transition is associated with an abnormal great thickness of marine deposits below continental deposits (for example, S2, ca 800 m; Fig. 11D and F; since S2 is only ca 200 m, ca 20 km towards west; Fig. 11B). The appearance of coarse-grained continental deposits, without shifting back to open-marine sedimentation, suggests the final subaerial exposure of the coastal environment involved by the 'fold and thrust' belt advance (Heller et al., 1988; DeCelles \& Giles, 1996; Sinclair, 1997). In the La Roize section (Fig. 11E), however, Gilbert deltas were observed overlying braided river deposits (Fig. 16). Therefore, this succession involves both an abrupt steepening of the slope controlled by tectonic activity, and a coeval increase of seawater depth that may be eustatic-driven or flexural-driven, or both. All in all, the occurrence of thick units of coarse-grained deltaic deposits argues for the tectonically-controlled proximal depozone progradation towards the distal depozone (Fig. 15), in response to the thrust belt advance.

The transgressions recorded at the base of S1, S2 and S3 coincide well with eustatic sea-level rises (Miller et al., 2005; Fig.12). This is coherent because most of the Strontium dating information comes from marine shell samples collected from distal depozone deposits. In this area, flexural subsidence rates act on a longer timescale than eustatic sea-level variations (Van Wagoner, 1995). However, in

This article is protected by copyright. All rights reserved 
the tectonically active proximal depozone, age control is usually very poor due to the rarity of marine shells, thus making the origin of RSL changes difficult to assess.

\section{Repetitive changes of depositional models during a third-order sequences and possible forcing}

\section{mechanisms}

Changes of primary depositional models are repetitively observed along the log sections (Fig. 11).

Once compared to the third-order relative sea-level changes, a similar and recurrent pattern was highlighted for the two depozones (Fig. 17).

During the earliest stage of the transgression, in the distal depozone, the co-existence of either tidedominated or wave-dominated environments suggests a complex transgression controlled by topographic inheritance. The narrow seaway configuration favours flow constriction, and thus tidal amplification (Reynaud \& Dalrymple, 2012; Longhitano et al., 2014). Furthermore, the irregular coastline morphology, in which the transgression occurred (Fig. 14), probably amplified even more tidal currents due to the local flow constriction effect in palaeotopographical lows (for example, tidal dunes from 0 to $20 \mathrm{~m}$ in the Chailles Est section, locality 16, Fig. 11C; photographs of tidal dunes from locality 14 in Fig. 6C, D and F; palaeo-landscape shown in Fig. 14B and D). Along the shorelines and on the palaeo-highs, however, wave action can be dominant over tide, and wavedominated, tide-modulated, environments commonly developed (for example, beach deposits from 0 to $22 \mathrm{~m}$ in the Loisieux section in Fig.11B; photographs in Fig. 2C; palaeo-landscape shown in Fig. $14 \mathrm{~B}$ and D as locality 13). During the continuing transgression, the tidal influence decreases and waves become predominant (Fig.17), as inferred from wave-dominated or mixed wave-tide sedimentary environments. By contrast, in the proximal depozone, close to the orogenic front and at river mouths, river-dominated coastlines with Gilbert deltas built up in response to rising sea levels or tectonically-driven increases in slope gradient (190 to $240 \mathrm{~m}$ of La Roize section, Fig. 11E, photographs in Figs 10A and 16).

During the earliest stage of the regression (Fig.17) in the distal depozone, mixed wave-tide depositional environments (WT) prevailed (for example, 740 to $770 \mathrm{~m}$ of Forezan section, Fig. 11F, pictures in Fig. 4A to $\mathrm{H}$ ). Indeed, during high sea levels, the width of the seaway is important, involving sufficient fetch for a sustained wave influence and making tidal amplification by flow

This article is protected by copyright. All rights reserved 
constriction less important. The wave action thus prevailed over tide action. Indeed, the smoothing of the coastline rugosity (due to infilling transgressive deposits) may have reduced tide amplification by local flow constriction (incised valleys) or diffraction, and correlatively enhanced wave action. During the latest stage of the regression, the prevalence of mixed river-tide sedimentary environments suggests that the seaway progressively became narrower and shallower. Wave action then decreased while tidal amplification increased, and rivers prograded towards the basin. At this stage, the proximal depozone is characterised first by the progradation of Gilbert delta clinoforms, before flat-lying fan delta deposits occurred and capped sedimentary successions (Figs 16 and 17).

\section{Common sedimentary patterns in foreland basins}

In the present study, changes of depositional environments were identified along third-order RSL changes (Fig. 17). This section aims to integrate the results of this study with other well-documented foreland basin overfilled phases (Fig. 18): the RPMB (Rhodano-Provencal Molassic Basin, Alpine peripheral foreland basin; location in Fig. 1); the EB (Ebron Basin, Pyrenean peripheral foreland basin); and the WISNA (Western Interior Seaway of North America, Laramide retro-arc foreland basin).

In the distal depozone, during the initial stage of the transgression, tides are always dominant in incised valleys because of local flow constriction. Later in the transgression, a large panel of wave to tide-dominated facies was described (Fig. 18). This is most likely the result of the basin configuration allowing tidal amplification by flow constriction (narrow seaway) and wave development (wide seaway). The influence of the local coastal morphology is also currently involved. Generally, the maximum water depth remains shallow $(<100 \mathrm{~m})$ in the basin. At the beginning of the regressions, shorelines in the distal depozone are mostly wave-dominated (W), sometimes wave-dominated and tide-modulated, such as in the present study (Fig. 18).

In the proximal depozone (Fig. 18), sedimentary sequences are characterized by both the aggradation and progradation of alluvial to deltaic deposits. In this tectonically active configuration, the identification of RSL changes is complex, especially when sequences are exclusively non-marine. In the EB peripheral foreland basin, the RSL changes were clearly tectonically-driven (Burns et al., 1997; López-Blanco et al., 2000). It is also concurrent with the results of this study that associate

This article is protected by copyright. All rights reserved 
gravel-rich fan-delta progradation with the fold and thrust belt advance. Instead, in the WISNA retroarc foreland basin, the third-order, fourth-order and fifth-order sequences were likely eustaticallydriven (Schwans, 1995; Van Wagoner, 1995). This agrees well with the sequence stratigraphic pattern of foreland ramp-type basins proposed by Posamentier \& Allen (1993a; b). This difference might be the result of different geodynamical settings (in retro-arc foreland basins, the entire flexural profile is tilted due to the far field dynamic loading transmitted to the lithosphere by viscous coupling between the subducting oceanic slab and the mantle wedge; Decelles, 2012), or by complex interactions between allocyclic and autocyclic processes involved in such a tectonically active and subsiding internal area.

\section{CONCLUSION}

The studied Early Miocene deposits of the subalpine massifs and southern Jura region (France) correspond to sedimentary successions belonging to the overfilled phase of a peripheral foreland basin. A thorough facies sedimentology study model was conducted and enabled to decipher 11 facies associations, which were grouped into four depositional models: wave-dominated, mixed wave-tide, river to tidal and river-dominated Gilbert-delta environments. This study further provides, for the first time in the study area, undisputable evidence of mixed-energy environments through a detailed analysis of sedimentary structures (i.e. combined wave-flow ripples and/or ridges and runnels).

Most of the 35 sedimentological sections analysed here were dated using chemostratigraphy (i.e. Strontium dating). Three third-order sequences were identified (S1, S2 and S3) between the Upper Aquitanian and the Langhian, revealing prominent and recurrent changes of depositional models. Using such results, a model tackling the evolution of process changes within third-order sequences of foreland basins is proposed, thereby improving sequence stratigraphic predictions in foreland basins. This model is then compared with overfilled phase successions from other foreland basins worldwide.

One of the main issues to be tackled in forthcoming studies concerns relative sea-level (RSL) change correlations between the proximal depozone and the distal depozone. In the distal depozone, RSL changes are often most likely eustatically-driven. However, in the tectonically active uplifted proximal depozone, RSL changes are clearly tectonically triggered. Hence the development of better

This article is protected by copyright. All rights reserved 
dating constraints on sedimentary deposits from proximal depozone (dominated by non-marine deposits) is mandatory for a detailed understanding of the dynamic relationships between tectonics and sedimentation in foreland basins.

\section{ACKNOWLEDGEMENTS}

The authors would like to thank TOTAL (CSTJF- Pau, France) for the financing of this PhD study. We would like to thank Frederic Quillévéré, Daniel Michoux and Frederic Ricciardi for biostratigraphic additional data and Davide Olivero for the identification of ichnofossils. We are also grateful to Andrea-Lopez Vega, Thomas Pichancourt, Astrid Jonet, Romain Grime, Antoine Mercier, Alessandro Menini, Thomas \& Pierre Courrier, Daniel Fournier, Ludovic Mocochain, Sidonie Revillon, Hugues Fenies, Jonathan Pelletier, Philippe Duringer, Xavier Du-Bernard, Jean-Pierre Girard and Francois Lafont for their precious help in the field and/or for fruitful discussions. We are also very grateful to reviewers Jean-Yves Reynaud and Valentina Rossi for their constructive and helpful comments that helped to improve the manuscript.

This article is protected by copyright. All rights reserved 


\section{REFERENCES}

Ahokas, J.M., Nystuen, J.P. and Martinius, A.W. (2014) Depositional dynamics and sequence development in a tidally influenced marginal marine basin: Early Jurassic Neill Klinter Group, Jameson Land Basin, East Greenland. From Depos. Syst. to Sediment. Successions Nor. Cont. Margin., 46, 291-337.

Ainsworth, R.B., Flint, S.S. and Howell, J.A. (2008) Predicting Coastal Depositional Style: Influence of Basin Morphology and Accommodation to Sediment Supply Ratio within a Sequence Stratigraphic Framework. Recent Adv. Model. Siliciclastic Shallow-Marine Stratigr. 90:0.

Ainsworth, R.B., Vakarelov, B.K. and Nanson, R.A. (2011) Dynamic spatial and temporal prediction of changes in depositional processes on clastic shorelines: toward improved subsurface uncertainty reduction and management. Am. Assoc. Pet. Geol. Bull., 95, 267-297.

Allen, P.A. and Bass, J.P. (1993) Sedimentology of the upper marine molasse of the Rhône-Alp Region, Eastern France: implications of basin evolution. Eclogae Geol. Helv., 86, 121-172.

Anadón, P., Cabrera, L., Colombo, F., Marzo, M. and Riba, O. (1986) Syntectonic intraformational unconformities in alluvial fan deposits, eastern Ebro Basin margins (NE Spain). Forel. basins, 8, 259-271.

Anthony, E.J., Levoy, F. and Monfort, O. (2004) Morphodynamics of intertidal bars on a megatidal beach, Merlimont, Northern France. Mar. Geol., 208, 73-100.

Anthony, E.J. and Orford, J.D. (2002) Between Wave- and Tide-Dominated Coasts: the Middle Ground Revisited. J. Coast. Res., 36, 8-15.

Ashley, G.M. (1990) Classification of large-scale subaqueous bedforms; a new look at an old problem. J. Sediment. Res., 60, 160-172.

Bass, J.P. (1991) The sedimentology and basin evolution of the upper marine molasse of the RhôneAlp region, France. $\mathrm{PhD}$ Thesis, University of Oxford, Oxford, 201 pp.

Belknap, D.F. and Kraft, J.C. (1985) Influence of antecedent geology on stratigraphic preservation potential and evolution of Delaware's barrier systems. Mar. Geol., 63, 235-262.

Berger, J.-P. (1992) Correlative chart of the European Oligocene and Miocene: application to the Swiss Molasse Basin. Eclogae Geol. Helv., 85, 573-609.

This article is protected by copyright. All rights reserved 
Berger, J.-P. (1985) La transgression de la molasse marine supérieure (OMM) en Suisse occidentale. Munchn. geowiss. Abh. R. A, 5, 207.

Berne, S., Auffret, J. and Walker, P. (1988) Internal structure of subtidal sandwaves revealed by high-resolution seismic reflection. Sedimentology, 35, 5-20.

Besson, D., Clauzon, G., Coueffe, R., Dexcote, Y., Ferry, S., Gonzalo, J., Mocochain, L., Parize, O., Rubino, J.L. and Suc, J.P. (2002) Le Néogène de bassin d'avant pays rhodano-provençal. In: Livret-guide excursion congrès international "Strati 2002, Lyon,” Publ. spec. Soc. Geol. France, 162.

Besson, D., Parize, O., Rubino, J.L., Aguilar, J.P., Aubry, M.P., Beaudoin, B., Berggren, W.A., Clauzon, G., Crumeyrolle, P., Dexcoté, Y., Fiet, N., Iaccarino, S., Jiménez-Moreno, G., Laporte-Galaa, C., Michaux, J., von Salis, K., Suc, J.P., Reynaud, J.Y. and Wernli, R. (2005) Un réseau fluviatile d'âge Burdigalien terminal dans le Sud-Est de la France: Remplissage, extension, âge, implications. Comptes Rendus - Geosci., 337, 1045-1054.

Bizon, G. and Bizon, J.-J. (1972) Atlas des principaux foraminifères planctoniques du bassin méditerranéen: oligocène à quaternaire. Éditions Technip.

Blanc, E. (1991) Evolution sédimentaire syntectonique au front d'une chaîne de collision en environnement littoral. Mem. DEA., 35 pp, Université de Chambéry, 35 pp.

Bocquet, J. (1966) Le delta miocène de Voreppe. Etude des faciès conglomératiques du Miocène des environs de Grenoble. Trav. du Lab. Géologie l'Université Grenoble, 42, 53-75.

Boersma, J.R. (1969) Internal structure of some tidal mega-ripples on a shoal in the Westerschelde Estuary, The Netherlands. Geol. en Mijnbouw/Netherlands J. Geosci., 48, 409-414.

Burbank, A., Engesser, D.W., Matter, B., Burbank, D.W., Engesser, B. and Matter, A. (1992) Magnetostratigraphic chronology, mammalian faunas, and stratigraphic evolution of the France Magnetostratigraphic chronology, mammalian faunas, and stratigraphic evolution of the Lower Freshwater. Eclogae Geol. Helv., 85, 399-431.

Burns, B.A., Heller, P.L., Marzo, M. and Paola, C. (1997) Fluvial response in a sequence stratigraphic framework; example from the Montserrat fan delta, Spain. J. Sediment. Res., 67, $311-321$.

Butler, R.W.H. (1992) Thrusting patterns in the NW French Subalpine chains. In: Annales

This article is protected by copyright. All rights reserved 
Tectonicae, 6, 150-172.

Cabello, P., Falivene, O., López-Blanco, M., Howell, J., Arbués, P. and Ramos, E. (2010)

Modelling facies belt distribution in fan deltas coupling sequence stratigraphy and geostatistics:

The Eocene Sant Llorenç del Munt example (Ebro foreland basin, NE Spain). Mar. Pet. Geol., 27, 254-272.

Clauzon, G. (1990) Genèse et évolution du piémont néogène subalpin du Bas-Dauphiné, F.Degaugue. Université d'Aix-en-Provence, 78 pp.

Crumeyrolle, P., Rubino, J. and Clauzon, G. (1991) Miocene depositional sequences within a tectonically controlled transgressive-regressive cycle. Sedimentation, Tectonics Eustasy Sea-Level Chang. Act. Margins, 3, 371-390.

Dalrymple, R.W., Baker, E.K., Harris, P.T. and Hughes, M.G. (2003) Sedimentology and stratigraphy of a tide-dominated, foreland-basin delta (Fly River, Papua New Guinea).

Dalrymple, R.W. and Rhodes, R.N. (1995) Estuarine dunes and bars. In: Geomorphology and Sedimentology of Estuaries (Ed. G.M.. Perillo), Elsevier, 53, 359-422.

Decelles, P.G. (2012) Foreland Basin Systems Revisited: Variations in Response to Tectonic Settings. In: Tectonics of Sedimentary Basins: Recent Advances (Ed. C. Busby and A. Perez), WileyBlackwell, 405-426.

DeCelles, P.G. and Giles, K.A. (1996) Foreland basin systems. Basin Res., 8, 105-123.

Defant, A. (1961) Physical Oceanography. Pergamon Press, Oxford, 598 pp.

Demarcq, G. (1962) Etude stratigraphique du Miocène rhodanien. Mém. BRGM., 61, 257.

Dickinson, R.W. (1974) Plate tectonics and sedimentation. In: Tectonics and Sedimentation (Ed. R.W. Dickinson), Special Publications of SEPM, 22, 1-27.

Dunbar, C.-O. and Rodgers, J. (1957) Principles of Stratigraphy. Geol. Mag., 94, 518.

Duncan, P.F. and Wilson, G. (2012) A new species of Pecten (Mollusca: Bivalvia: Pectinidae) from northern Western Australia. Molluscan Res., 32, 21.

Fenies, H., De Resseguier, A. and Tastet, J. (1999) Intertidal clay-drape couplets (Gironde estuary, France). Sedimentology, 46, 1-15.

Fenies, H. and Faugères, J.-C. (1998) Facies and geometry of tidal channel-fill deposits (Arcachon Lagoon, SW France). Mar. Geol., 150, 131-148.

This article is protected by copyright. All rights reserved 
Ferret, Y. (2011) Morphodynamique de dunes sous-marines en contexte de plate-forme mégatidale (Manche Orientale). Approche multi-échelles spatio-temporelles. PhD Thesis, Université de Rouen, 296 pp.

Frouin, M., Sebag, D., Durand, A., Laignel, B., Saliege, J.-F., Mahler, B.J. and Fauchard, C. (2007) Influence of paleotopography, base level and sedimentation rate on estuarine system response to the Holocene sea-level rise: the example of the Marais Vernier, Seine estuary, France. Sediment. Geol., 200, 15-29.

Gidon, M., Arnaud, H. and Montjuvent, A. (1978) Notice explicative, Carte géol. France (1/50000), feuille Grenoble (772). BRGM, Orléans, 37 pp.

Gilbert, G.K. (1885) The topographic features of lake shores. US Geol. Surv. Ann. Rep, 5, 69-123.

Giot, P.R. (1944) Contribution à l'étude des terrains tertiaires du Royans (Isère et Drôme). Trav. Lab. Géol. Grenoble, 24, 49-68.

Gobo, K. (2014) Development of Gilbert-type deltas : sedimentological case studies from the PlioPleistocene of Corinth Rift, Greece. PhD Thesis, University of Bergen, $30 \mathrm{pp}$.

Gradstein, F.M., Ogg, J.G. (James G. and Smith, A.G. (Alan G. (2004) A geologic time scale 2004. Cambridge University Press, 589 pp.

Heller, P.L., Angevine, C.L., Winslow, N.S. and Paola, C. (1988) Two-phase stratigraphic model of foreland-basin sequences. Geology, 16, 501-504.

Homewood, P. (1981) Faciès et environnements de dépôt de la Molasse de Fribourg. Eclogae Geol. Helv., 74, 29-36.

Homewood, P., Guillocheau, F., Eschard, R. and Cross, T.A. (1992) Corrélations haute résolution et stratigraphie génétique: une démarche intégrée. Bull. des Centres Rech. Explor. Elf-Aquitaine, 16, 357-381.

Ichaso, A.A. and Dalrymple, R.W. (2009) Tide-and wave-generated fluid mud deposits in the Tilje Formation (Jurassic), offshore Norway. Geology, 37, 539-542.

James, N.P., Seibel, M.J., Dalrymple, R.W., Besson, D. and Parize, O. (2014) Warm-temperate, marine, carbonate sedimentation in an Early Miocene, tide-influenced, incised valley; Provence, south-east France. Sedimentology, 61, 497-534.

Jodot, P. (1955) Dimensions réduites des Limnées oligocènes du Jura suisse. C.R. Somm. Soc. Fr, 11,

This article is protected by copyright. All rights reserved 
$213-215$.

King, C.A.M. (1972) Beaches and coasts. Edward Arnold, 570 pp.

Kreisa, D.R. and Moila, R.J. (1986) Sigmoidal tidal bundles and other tide-generated sedimentary structures of the Curtis Formation, Utah. Geol. Soc. Am. Bull., 97, 381.

Kroon, A. and Masselink, G. (2002) Morphodynamics of intertidal bar morphology on a macrotidal beach under low-energy wave conditions, North Lincolnshire, England. Mar. Geol., 190, 591608.

Kwasniewski, A. (2010) Synthèse géologique du bassin de Valence, Sud-est de la France. MS Thesis, IFP school, Rueil-Malmaison, 16 pp.

Lamiraux, C. (1977) Géologie du Miocène des chainons jurassiens méridionaux et du Bas-Dauphiné nord oriental entre Chambéry et La Tour du Pin: étude stratigraphique, sédimentologique et tectonique. PhD Thesis, Université Scientifique et Médicale de Grenoble, 174 pp.

Latreille, G. (1969) La sédimentation détritique au Tertiaire dans le Bas-Dauphiné et les régions limitrophes. PhD Thesis, Université de Lyon, 340 pp.

Leva López, J., Rossi, V.M., Olariu, C. and Steel, R.J. (2016) Architecture and recognition criteria of ancient shelf ridges; an example from Campanian Almond Formation in Hanna Basin, USA. Sedimentology, 63, 1651-1676.

Li, C., Wang, P., Daidu, F., Bing, D. and Tiesong, L. (2000) Open-coast intertidal deposits and the preservation potential of individual laminae: A case study from east-central China. Sedimentology, 47, 1039-1051.

Longhitano, S.G. (2013) A facies-based depositional model for ancient and modern, tectonicallyconfined tidal straits. Terra Nov., 25, 446-452.

Longhitano, S.G., Chiarella, D. and Muto, F. (2014) Three-dimensional to two-dimensional crossstrata transition in the lower Pleistocene Catanzaro tidal strait transgressive succession (southern Italy). Sedimentology, 61, 2136-2171.

López-Blanco, M., Marzo, M. and Piña, J. (2000) Transgressive-regressive sequence hierarchy of foreland, fan-delta clastic wedges (Montserrat and Sant Llorenç del Munt, Middle Eocene, Ebro Basin, NE Spain). Sediment. Geol., 138, 41-69.

Malikides, M., Harris, P.T., Jenkins, C.J. and Keene, J.B. (1988) Carbonate sandwaves in Bass

This article is protected by copyright. All rights reserved 
Strait. Aust. J. Earth Sci., 35, 303-311.

Masselink, G., Kroon, A. and Davidson-Arnott, R.G.D. (2006) Morphodynamics of intertidal bars in wave-dominated coastal settings - a review. Geomorphology, 73, 33-49.

Masselink, G. and Short, A.D. (1993) The effect of tide range on beach morphodynamics and morphology: a conceptual beach model. J. Coast. Res., 9, 785-800.

McAnally, W.H., Friedrichs, C., Hamilton, D., Hayter, E., Shrestha, P., Rodriguez, H., Sheremet, A., Teeter, A. and Mud, A.T.C. on M. of F. (2007) Management of fluid mud in estuaries, bays, and lakes. I: Present state of understanding on character and behavior. $J$. Hydraul. Eng., 133, 9-22.

McArthur, J.M., Howarth, R.J. and Shields, G.A. (2012) Strontium Isotope Stratigraphy. Geol. Time Scale 2012, 1-2, 127-144.

McPherson, J.G., Shanmugam, G. and Moiola, R.J. (1987) Fan-deltas and braid deltas: varieties of coarse-grained deltas. Geol. Soc. Am. Bull., 99, 331-340.

Miller, K.G., Kominz, M.A., Browning, J. V., Wright, J.D., Mountain, G.S., Katz, M.E., Sugarman, P.J., Cramer, B.S., Christie-Blick, N. and Pekar, S.F. (2005) The phanerozoic record of global sea-level change. Science (80-. )., 310, 1293-1298.

Mortaz-Djalili, D. (1977) Sédimentologie des formations détritiques du Néogène du plateau de Chambaran (Bas-Dauphiné, France). PhD Thesis, Université Scientifique et Médicale de Grenoble, $153 \mathrm{pp}$.

Mortaz-Djalili, D. and Perriaux, J. (1979) Le Néogène du Plateau de Chambaran (Bas-Dauphiné, France). Géologie Alp., 55, 133-152.

Mujito, S. (1981) Les sédiments tertiaires dans le Jura méridional et les Bauges occidentales: Savoie, Haute Savoie (France)-Alpes françaises. PhD Thesis, Université Scientifique et Médicale de Grenoble, 221 pp.

Nicolas, A., Polino, R., Hirn, R., Nicolich, R. and Group, E.-C. working (1990) ECORS-CROP traverse and deep structure of the western Alps: a synthesis. In: A synthesis, in Deep structure of the Alps (Ed. F. Roure, P. Heitzmann, and R. Polino), Mém. Soc. Geol. France, NS, 15-27.

Nicolet, C. (1979) Le Bas-Dauphiné septentrional: étude stratigraphique et sédimentologique. $\mathrm{PhD}$ Thesis, Université Scientifique et Médicale de Grenoble, 150 pp.

This article is protected by copyright. All rights reserved 
Olariu, C. (2014) Autogenic process change in modern deltas: lessons for the ancient. From Depos. Syst. to Sediment. Successions Nor. Cont. Margin, 149-166.

Pelin, S. (1965) Etude géologique du bassin de Pont-en-Royans Vercors-Alpes françaises. $\mathrm{PhD}$ Thesis, Université de Grenoble, 68 pp.

Pelletier, J. (2012) Faciès, architecture et dynamique d'un système margino-littoral tidal : exemple de la Formation du Dur At Talah (Eocène supérieur, Bassin de Syrte, Libye). PhD Thesis, Université de Strasbourg, 470 pp.

Peng, Y., Steel, R.J., Rossi, V.M. and Olariu, C. (2018) Mixed-energy process interactions read from a compound-clinoform delta (paleo-Orinoco Delta, Trinidad): preservation of river and tide signals by mud-induced wave damping. J. Sediment. Res., 88, 75-90.

Pfiffner, O.-A., Lehner, P., Heitzmann, P., Mueller, S. and Steck, A. (1997) Deep structure of the Swiss Alps: results of NRP 20. Birkhäuser, Basel, 380 pp.

Pfiffner, O.A. (1986) Evolution of the north Alpine foreland basin in the Central Alps. In: Foreland basins (Ed. P.A. Allen and P. Homewood), Blackwell Scientific Publications, 219-228.

Plink-Björklund, P. (2012) Effects of tides on deltaic deposition: Causes and responses. Sediment. Geol., 279, 107-133.

Plink-Björklund, P., Hampson, G.J., Steel, R.J., Burgess, P.M. and Dalrymple, R.W. (2008) Wave-to-tide facies change in a Campanian shoreline complex, Chimney Rock Tongue, Wyoming-Utah, USA. Recent Adv. Model. shallow-marine Stratigr. SEPM Spec. Publ., 90, 265291.

Posamentier, H.W. and Allen, G.P. (1993a) Siliciclastic sequence stratigraphic patterns in foreland, ramp-type basins. Geology, 21, 455-458.

Posamentier, H.W. and Allen, G.P. (1993b) Variability of the sequence stratigraphic model: effects of local basin factors. Sediment. Geol., 86, 91-109.

Postma, G. and Roep, T.B. (1985) Resedimented conglomerates in the bottomsets of Gilbert-type gravel deltas. J. Sediment. Res., 55, 874-885.

Pugh, D. (1987) Tides, Surges and Mean Sea-Level. John Wiley and Sons, Chichester, 472 pp.

Reading, H.G. (1996) Sedimentary environments : processes, facies, and stratigraphy, 3rd editio. Blackwell Science, 688 pp.

This article is protected by copyright. All rights reserved 
Reichmüth, B. and Anthony, E.J. (2007) Tidal influence on the intertidal bar morphology of two contrasting macrotidal beaches. Geomorphology, 90, 101-114.

Reineck, H. and Wunderlich, F. (1968) Classification and origin of flaser and lenticular bedding. Sedimentology, 11, 99-104.

Reynaud, J.-Y. and Dalrymple, R.W. (2012) Shallow-marine tidal deposits. In: Principles of Tidal Sedimentology (Ed. R.A. Davis and R.W. Dalrymple), Springer, Dordrecht, 335-369.

Reynaud, J.-Y., Dalrymple, R.W., Vennin, E., Parize, O., Besson, D. and Rubino, J.-L. (2006) Topographic controls on production and deposition of tidal cool-water carbonates, Uzes Basin, SE France. J. Sediment. Res., 76, 117-130.

Reynaud, J.-Y., Ferrandini, M., Ferrandini, J., Santiago, M., Thinon, I., ANDRÉ, J., Barthet, Y., Guennoc, P.O.L. and Tessier, B. (2013) From non-tidal shelf to tide-dominated strait: The Miocene Bonifacio Basin, Southern Corsica. Sedimentology, 60, 599-623.

Reynaud, J.-Y. and James, N.P. (2012) The Miocene Sommières basin, SE France: Bioclastic carbonates in a tide-dominated depositional system. Sediment. Geol., 282, 360-373.

Reynaud, J.-Y., Vennin, E., Parize, O., Rubino, J.-L. and Bourdillon, C. (2012) Incised valleys and tidal seaways: the example of the Miocene Uzès-Castillon basin, SE France. Bull. la Société Géologique Fr., 183, 471-486.

Rossi, V.M., Longhitano, S.G., Mellere, D., Dalrymple, R.W., Steel, R.J., Chiarella, D. and Olariu, C. (2017a) Interplay of tidal and fluvial processes in an early Pleistocene, delta-fed, strait margin (Calabria, Southern Italy). Mar. Pet. Geol., 87, 14-30.

Rossi, V.M., Olaussen, S., Staine, I.N. and Gennaro, M. (2020) Development of the Middle Triassic Kobbe Formation shelf-margin prism and transgressive-regressive cycles on the shelf (Hammerfest Basin, SW Barents Sea). Mar. Pet. Geol., 111, 868-885.

Rossi, V.M., Perillo, M.M., Steel, R.J. and Olariu, C. (2017b) Quantifying mixed-process variability in shallow-marine depositional systems: What are sedimentary structures really telling us? J. Sediment. Res., 87, 1060-1074.

Rossi, V.M. and Steel, R.J. (2016) The role of tidal, wave and river currents in the evolution of mixed-energy deltas: Example from the Lajas Formation (Argentina). Sedimentology, 63, 824864.

This article is protected by copyright. All rights reserved 
Rubino, J.L., Lesueur, J.L. and Clauzon, G. (1990) Le Miocène inférieur et moyen du bassin rhodanien: stratigraphie séquentielle et sédimentologie, ASF. ASF, 67 pp.

Schwans, P. (1995) Controls on Sequence Stacking and Fluvial to Shallow-Marine Architecture in a Foreland Basin. In: M 64: Sequence Stratigraphy of Foreland Basin Deposits, AAPG Speci (Ed. J.C. Van Wagoner and G.T. Bertram), AAPG Special Volumes, 55-102.

Short, A.D. (1991) Macro-meso tidal beach morphodynamics: an overview. J. Coast. Res., 7, 417436.

Short, A.D. (1984) Beach and nearshore facies: southeast Australia. Mar. Geol., 60, 261-282.

Sinclair, H.D. (1997) Tectonostratigraphic model for underfilled peripheral foreland basins: An Alpine perspective. Bull. Geol. Soc. Am., 109, 324-346.

Sinclair, H.D. and Allen, P.A. (1992) Vertical versus horizontal motions in the Alpine orogenic wedge: Stratigraphic response in the foreland basin. Basin Res., 4, 215-232.

Steel, R.J., Plink-Bjorklund, P. and Aschoff, J. (2012) Tidal deposits of the Campanian Western Interior Seaway, Wyoming, Utah and Colorado, USA. In: Principles of tidal sedimentology, Springer, 437-471.

Surlyk, F. (1984) Fan-delta to submarine fan conglomerates of the Volgian-Valanginian Wollaston Foreland Group, East Greenland. Can. Soc. Pet. Geol. Mem., 10, 359-382.

Tessier, B., Billeaud, I., Sorrel, P., Delsinne, N. and Lesueur, P. (2012) Infilling stratigraphy of macrotidal tide-dominated estuaries. Controlling mechanisms: Sea-level fluctuations, bedrock morphology, sediment supply and climate changes (The examples of the Seine estuary and the Mont-Saint-Michel Bay, English Channel, NW France). Sediment. Geol., 279, 62-73.

Thomas, R.G., Smith, D.G., Wood, J.M., Visser, J., Calverley-Range, E.A. and Koster, E.H. (1987) Inclined heterolithic stratification - terminology, description, interpretation and significance. Sediment. Geol., 53, 123-179.

Traykovski, P., Geyer, W.R., Irish, J.D. and Lynch, J.F. (2000) The role of wave-induced densitydriven fluid mud flows for cross-shelf transport on the Eel River continental shelf. Cont. Shelf Res., 20, 2113-2140.

Vail, P.R., Audemard, F., Eisner, P.. and Perez-cruz, C. (1991) The stratigraphic signatures of tectonics, eustacy and sedimentology-an overview. In: Cycles and events in stratigraphy (Ed. G.

This article is protected by copyright. All rights reserved 
Einsele, W. Ricken, and A. Seilacher), Springer-Verlag, 617-659.

Vakarelov, B.K., Ainsworth, R.B. and MacEachern, J.A. (2012) Recognition of wave-dominated, tide-influenced shoreline systems in the rock record: Variations from a microtidal shoreline model. Sediment. Geol., 279, 23-41.

Van Wagoner, J.C. (1995) Sequence Stratigraphy and Marine to Nonmarine Facies Architecture of Foreland Basin Strata, Book Cliffs, Utah, U.S.A. In: M 64: Sequence Stratigraphy of Foreland Basin Deposits, The Americ (Ed. J.C. Van Wagoner and G.T. Bertram), AAPG Special Volumes, $137-223$.

Vaucher, R., Pittet, B., Hormière, H. and Martin, E.L.O. (2017) A wave-dominated, tidemodulated model for the lower ordovician of the anti-atlas, Morocco. Sedimentology, 64, 777807.

Vaucher, R., Pittet, B., Humbert, T. and Ferry, S. (2018a) Large-scale bedforms induced by supercritical flows and wave-wave interference in the intertidal zone (Cap Ferret, France). GeoMarine Lett., 38, 287-305.

Vaucher, R., Pittet, B., Passot, S., Grandjean, P., Humbert, T. and Allemand, P. (2018b)

Bedforms in a tidally modulated ridge and runnel shoreface (Berck-Plage; North France): implications for the geological record. BSGF - Earth Sci. Bull., 189, 5.

Visser, M.J. (1980) Neap-spring cycles reflected in Holocene subtidal large-scale bedform deposits: a preliminary note. Geology, 8, 543-546.

Walther, J. (1894) Einleitung in die Geologie als historische Wissenschaft. In: (Ed. F. Verlag), Bd 3, Lithogenesis der Gegenwart, 535-1055.

Wescott, W. and Ethridge, F.G. (1990) Fan deltas - alluvial fans in coastal settings. In: Alluvial fans: a field approach (Ed. A.H. Rachocki and M. Church), Wiley Chichester, 195-211.

Wright, L.D., Chappell, J., Thom, B.G., Bradshaw, M.P. and Cowell, P. (1979) Morphodynamics of reflective and dissipative beach and inshore systems: Southeastern Australia. Mar. Geol., 32, $105-140$.

Wright, L.D., May, S.K., Short, A.D. and Green, M.O. (1984) Beach and surf zone equilibria and response times. Coastal Eng., 19, 2150-2164.

Yang, B.C. and Chun, S.S. (2001) A seasonal model of surface sedimentation on the Baeksu open-

This article is protected by copyright. All rights reserved 
coast intertidal flat, southwestern coast of Korea. Geosci. J., 5, 251-262.

Yang, B.C., Dalrymple, R.W. and Chun, S.S. (2005) Sedimentation on a wave-dominated, opencoast tidal flat, south-western Korea: Summer tidal flat - Winter shoreface. Sedimentology, 52, $235-252$.

Yang, C. and Nio, S. (1985) The estimation of palaeohydrodynamic processes from subtidal deposits using time series analysis methods. Sedimentology, 32, 41-57.

Yoshida, S., Steel, R.J. and Dalrymple, R.W. (2007) Changes in Depositional Processes--An Ingredient in a New Generation of Sequence-Stratigraphic Models. J. Sediment. Res., 77, 447460.

Zhang, J., Rossi, V.M., Peng, Y., Steel, R. and Ambrose, W. (2019) Revisiting Late Paleocene Lower Wilcox deltas, Gulf of Mexico: River-dominated or mixed-process deltas? Sediment. Geol., 389, 1-12.

This article is protected by copyright. All rights reserved 


\section{FIGURE AND TABLE CAPTIONS}

Fig. 1. (A) Location map of the western Alpine foreland basin in yellow (map from Google Earth ${ }^{\circledR}$ ) and localization of the study area. (B) Simplified geological map of the study area corresponding to the subalpine massifs and southern Jura. The studied log sections are localized (1 to 35). (C) Miocene stratigraphy of the Bas-Dauphiné basin (modified from Kwasniewski, 2010). Comparison with Allen \& Bass (1993) Miocene stratigraphy of the southern Jura (Rumily, Chambéry and Novalaise areas) and the Swiss molassic basin stratigraphy.

Fig. 2. Sedimentary facies of wave-dominated offshore to shoreface sedimentary environments. (A) Bioturbated silts with laterally continuous accumulation levels of big-sized monospecific oysters (arrow in yellow, probably ex situ) suggesting distal tempestites and interpreted as F2 offshore deposits. (B) HCS interstratified in bioturbated silts interpreted as F3 offshore transition deposits. (C) and (D) Amalgamated oscillation structures interpreted as F4 shoreface deposits; (D) corresponds to the microfacies of F4, showing calcarenites very rich in biogenic components: $\mathrm{Br}=$ bryozoan; $\mathrm{Sh}=$ bivalve shell; $\mathrm{Fb}=$ benthic foraminifera.

Fig. 3. Sedimentary architecture and facies of wave-dominated shoreface to foreshore sedimentary environments: $\mathrm{Pl}=$ planar laminations; $\mathrm{Cb}=$ clinoform bottomsets; (A) Panoramic view from the Corbel road cliff. Red surfaces represent minor sequence boundaries (possibly fourth or fifth-order) on which foreshore deposits are onlapping. (B), (C), (D) and (F) are close-up views of (A). (B) F4 amalgamated oscillation structures onlapping on F6 beach berms; (D) is a close-up view showing F4 and F6 geometrical relationships. (C) F5 Foreshore (for example, beach) planar laminations overlain by oblique stratifications forming clinoforms that dip $20^{\circ}$ south-eastward. (D) F6 beach berm showing oblique tangential stratification corresponding to clinoform bottomsets: $\mathrm{B}=$ bioperforation. (E) Antidunes in F5. Red dotted arrows shows the migration of the crests in the south-west opposite current direction (north-east). Note the general decrease in dip on the forward slope, passing rapidly again to (sub-) planar lamination. Antidunes are attributed to supercritical currents, inducing stationary wave interferences in the swash zone (possibly during rising or falling tides). (F) Panoramic view of the Corbel road cliff. The red surface refers to an emersion surface: $(\mathrm{G})$ and $(\mathrm{H})$ are close-up views. The interpreted photographic panel below (F) shows the alternation between: in 
blue, onlapping planar laminated sandstones as retrograding beach clinoforms; in orange, prograding clinoforms (with downcutting at their distal end), as shown in the close-up (I). (G) Vertical bifurcated tube-like voids underlining the emersion surface (below the retrograding beach deposits), and interpreted as roots: $\mathrm{R}=$ roots, $\mathrm{L}=$ lag of pebbles. $(\mathrm{H})$ Palaeosoil (emersion surface) occurring below the retrograding beach deposits: Ps $=$ palaeosoil. (I) Prograding clinoforms downcutting the underlying beach deposits - red dotted line, see also on (F). The white surface is erosive and irregular, and the overlying deposits are rich in pebbles: (J) is a close-up view. (J) Small-scale oblique tangential cross-beds often downcutting in the bottomsets of the megaripples implying a likely tidemodulation in the genesis of those wave megaripples: $\mathrm{D}=$ downcutting.

Fig. 4. Sedimentary facies of the FA5 open-coast subtidal sedimentary environment; (A) Outcrop showing a F1, F7 and F8 vertical succession with the corresponding detailed photographs. (B) F1 Blue marls. Close-up view showing horizontal bioturbation (Planolites). (C) F7 facies showing sandstone lenses (lenticular bedding): (D) and (F) are close-ups focusing on one of the many sandstone lenses found in this facies, which are interpreted as combined wave-flow ripples. (D) Subsymmetrical combined wave-flow ripple showing unidirectional foreset progradation. Note, however, the successive reactivation surfaces cutting the foresets and the increase in leeward slope angularity, both implying a pervasive wave influence during the genesis of the ripple: (F) is a close-up view of the inner organization of the wave-flow ripple. Note the prominent increase in leeward slope angularity. (E) Detailed close-up of a combined wave-flow ripple within F7. The cross-cut is in the direction of progradation. Note the successive reactivation surfaces (red curved lines) cutting the foresets, the bidirectional foreset progradation (thus involving two opposite current directions) and the pattern of intermingled silt and clay deposits suggesting recurrent hydrodynamic changes during the genesis of the combined wave-flow ripple; i.e. a possible modulation by tides and a pervasive influence of waves. (F) Foreset laminae showing a recurrent pattern of silt and finer-grained (for example, mud) deposits involving a possible modulation by tides. Note the prominent increase in leeward slope angularity and the reworking surface at top. (G) F8 wavy bedding facies showing alternations of bidirectional sandy ripples and wavy, centimetre-thick and laterally continuous muddy layers (i.e. fluid mud). Relative mud/sand ratio repetitively varies vertically: $(H)$ is a close-up view.

This article is protected by copyright. All rights reserved 
(H) Symmetrical ripples in red. Note that the foreset laminae contain less intertwined mud laminations compared with $\mathrm{F} 7$ ripples shown in $(\mathrm{C})$ to $(\mathrm{F})$.

Fig. 5. Sedimentary facies of the FA6 open-coast intertidal sedimentary environment. (A) Outcrop showing an alternation of F8 and F9. F9 overlies F8 with sharp contacts, whereas the F9 to F8 transition is progressive: (B) is a close-up view of F9. (B) F9 sandstones. The flaser bedding pattern is continuous laterally - pluri decametre-scale, see (A). Towards the top, flaser bedding frequency increases and becomes wavier: Fl = flaser bedding. (C) Gutter cast below F9 sharp transition: Gc = gutter cast. (D) F10 Ridges and runnels facies. Alternation of laterally discontinuous sandstones (ridges) and fine-grained heterolithics (runnels). Sandstones gradually thin-up laterally and pass to fine-grained sediments, leading to a heterolithic facies: $€$ is a close-up view focusing on a runnel. (E) F10 sandstones in a ridge. Recurrent pattern of alternation between (sub-planar bedding with) aggrading symmetrical ripples (or hummock/swale structures; HCS/SCS) and bidirectional combined wave-flow ripples accreting laterally. (F) F10 heterolithics in a runnel showing combined wave-flow ripples. Note (above the red surface) the continuous reactivation of the ripples by waves, the predominance of one current direction (to the east), and the pervasive occurrence of downcutting in the bottomsets of the ripples.

Fig. 6. Sedimentary facies of the FA7 subtidal sedimentary environment. (A) F11 large-scale tidal dune: (E) is a close-up view on the bottomsets. (B) F11 large-scale tidal dune interstratified in AF1 offshore deposits. Red arrows shows a recurrent thickness variability of the cross-laminae, which were interpreted as tidal bundles. (C) F12 medium-scale tidal dunes. Northward-directed metre-scale oblique tangential foresets on the longitudinal view: (D) corresponds to the orthogonal view; (F) corresponds to the longitudinal view too, 5 to $10 \mathrm{~m}$ downstream from (C). (D) Pluri-metric trough cross-beds (or festoons), orthogonally to the northward-directed tangential cross-beds depicted on (C). (E) Heterolithic deposits showing bidirectional ripples in the bottomsets of the tidal dune shown in (A). (F) F12 medium-scale tidal dunes. Metre-scale sigmoid-shaped cross-strata prograding northward, interpreted as tidal bundles. $(\mathrm{G})$ and $(\mathrm{H})$ Trough cross-bedding of F13 small-scale tidal dunes. Thin discontinuous conglomeratic levels locally underline the cross-stratifications, as well as mud and organic matter drapes, locally as double drapes (black arrows), as shown in (H) close-up 
view. (I) and (J) F14 sandy tidal channel (incising mixed flat deposits below the red line) filled by bidirectional decimetre-scale cross-bedded sandstones (black lines) organized along large-scale lowangle inclined surfaces (white lines). (K) and (L) F14 heterolithic tidal channel infill (i.e. IHS) showing low-angle inclined heterolithic deposits onlapping on erosive low-angle surfaces (red lines) covered by mud clasts and bioclasts: $\mathrm{Oy}=$ oyster fragments: $(\mathrm{M})$ and $(\mathrm{N})$ are close up-views on heterolithics. (M) and (N) Heterolithic infill of F14 tidal channel consists of flaser to wavy bedding alternation containing bidirectional ripples and load casts. Red lines correspond to minor erosive surfaces: $\mathrm{Lc}=$ load cast; $\mathrm{Mc}=$ mud clast; $\mathrm{Sd}=$ sands; $\mathrm{C}=$ clays; $\mathrm{St}=$ silts.

Fig. 7. Sedimentary facies of the FA8 intertidal sedimentary environment. (A) F15 sand flat. Pluridecimetre oblique tangential cross-beds: (B) is a close-up view on the bottomsets of the megaripples. (B) Amalgamated centimetre-scale trough-cross beds interpreted as run-off ripples in the trough of the cross-beds shown on (A). (C) F16 mixed-flat. Repetitive alternation between sandy levels including mud clasts (and current ripples at top) and lenticular bedding levels showing bidirectional current ripples as pinpointed in the close-up view. The lowest part of photograph (C) shows oblique crossbeds (as underlined by the mud clasts, see black dashed line) likely corresponding to lateral accretion in a tidal creek. Mc $=$ Mud clasts. (D) F16 mixed-flat. Millimetre-scale rill-marks. (E) F16 mixed-flat. Loadcasts. (F) F17 tidal creek. Metre-scale incision filled by sandstones interstratified within F16 mixed-flat heterolithic deposits. (G) and (H) F17 Tidal creek. Metre-scale incision within F15 sand flat deposits filled by sandstones containing mud clasts, as shown in $(\mathrm{H})$ close-up view.

Fig. 8. Sedimentary facies of the FA9 river-to-tidal transition and FA10 river sedimentary environments with F19 braided-river system. (A) F18 river-mouth. One-metre deep gutter-cast infilled by oblique tangential cross-stratified pebbles/cobbles. The gutter-cast structure is erosive on the underlying F15 sand flat deposits, suggesting that fluvial inputs were permanently reworked by tides. (B) F18 river-mouth: $\mathrm{Md}=$ mud drape; $\mathrm{L}=$ lag. One-metre deep gutter-cast infilled by oblique tangential cross-stratified sandstones showing mud drapes in the bottomsets. The gutter-cast is interstratified within sandstones and conglomerates (as laterally sheet-like continuous levels) suggesting fluvial inputs. (C) and (D) F18 river-mouth. Co-existence of tidal dunes (northwarddirected cross-beds with oppositely-directed ripples) and trough-cross bed indicating a perpendicular direction of currents likely suggesting river inputs. (E) F18 river-mouth: $G=$ gutter; $F=$ floods. 
Intermingled laterally continuous conglomerates and trough cross-bedded (= festoons) sandstones. The red surface underlines the onset of the conglomeratic F19 braided-river system. $(F),(G)$ and $(H)$ F18 river-mouth at the base and F19 braided-river deposits above the red surface. Note the pluri-metre gutter-like erosional surfaces, infilled by oblique tangential cross-stratified conglomerates: (G) and (H) are close-up views. Conglomerates are interstratified with sandstones including 5 to $10 \mathrm{~cm}$ thick levels rich in centimetric angular to rounded mud clasts, as shown in $(\mathrm{F})$. Oc $=$ Oriented pebbles emphasizing the oblique tangential cross-stratifications.

Fig. 9. Sedimentary facies of the FA10 river deposits and F22 palaeosoil. (A) and (B) F19 braidedriver deposits (above the red surface), showing flat-lying clast-supported conglomerates that form up thick massive units: (A) corresponds to the orthogonal section and shows an infilled channel incision at the base, passing upward to low-angle trough cross-bedded conglomerates; (B) corresponds to the longitudinal section. $\mathrm{S} 1$ = Sandstones lenses corresponding to locally preserved finer material onto the bars or in the deactivated channels between the fluvial bars. (C) F19 braided-river system. Normallygraded levels overlain by a palaeosoil: Ps = palaeosoil (F22). (D) F19 braided-river system. Flat-lying clast-supported conglomerates made of clasts of various sizes (from pebbles to boulders) indicating floods events, showing westward-directed imbrications: Im = imbrication. (E) F22 palaeosoil: $\mathrm{R}=$ rootlet.

Fig. 10. Sedimentary facies of the FA11 Gilbert delta sedimentary environment and F25 earthquakedisturbed layer. (A) F20 Gilbert delta showing westward-directed foresets (for example, deltaic clinoforms) overlying flat-lying conglomerates interpreted as F19 braided-river system. This succession suggests the creation of gradient slope. (B) Flat-lying conglomerates interpreted as F19 braided-river system overlying F20 Gilbert delta that depicts northward-directed foresets: (C) corresponds to an orthogonal view. (C) In this view, F20 Gilbert delta northward-directed foresets shown in (B) correspond to flat-lying conglomerates, which indicate a progradation in 2D. (D) $15 \mathrm{~cm}$ thick poorly sorted pebble level interstratified in F1 offshore deposits, interpreted as the bottomsets of a Gilbert delta (F21). (E) F25 earthquake-disturbed layer. Matrix-supported autochthonous decimetre to pluri-metre angular clasts. The organization is chaotic but the original stratification is preserved.

Fig. 11. Detailed log sections of the Miocene marine successions of the southern Jura synclines and the subalpine massifs (locations in Fig.1). (A) Key for the sedimentary logs displayed in (B) to (F).

This article is protected by copyright. All rights reserved 
Synthetic table of facies and facies associations, and the corresponding sedimentary environments. The mixed sedimentary environments are wave-tide (WT) and river-tide (RT), and are highlighted by light-grey shading. The different colours used to decipher the four depositional models are: (i) blue for the wave-dominated model; (ii) red for the mixed wave-tide model; (iii) light-orange for the river to tidal model; and (iv) green for the Gilbert delta model. Sedimentary captions for the log sections are presented at the bottom end of the figure. (B) The Loisieux section, locality 13 in Fig. 1, 15. (C) The Chailles Est section, locality 16 in Fig. 1, 15. (D) The Grésy section, locality 4 in Fig. 1. (E) The La Roize section, locality 20 in Fig. 1. (F) The Forezan section, locality 5 in Fig.1. In (B) to (F), from left to right: lithology, sedimentary structures, facies and facies associations, depositional processes, depositional models, sequence stratigraphy.

Fig. 12. ${ }^{87} \mathrm{Sr} /{ }^{86} \mathrm{Sr}$ values measured on shells (pectinids and oysters) of the studied Miocene deposits. According to McArthur et al. (2012), values have been normalized to the value of 0.710248 for the NBS987 standard and uncertainties on the mean age correspond to the uncertainty (at 95\% confidence level) of the measurements (sample and corresponding NBS standards) added to the uncertainty on the ${ }^{87} \mathrm{Sr} /{ }^{86} \mathrm{Sr}$ marine curve (LOWESS version 5). Propagated uncertainties are shown as standard errors of the mean values. The different colours used for the ${ }^{87} \mathrm{Sr} /{ }^{86} \mathrm{Sr}$ data points refer to the sequence stratigraphical position of the samples: dark-orange for the S1 transgression; lightorange for the S1 regression; dark-blue for the S2 transgression; light-blue for the S2 regression; and green for the S3 transgression. The red arrows outline the dating uncertainties calculated for the transitions spanning two successive stratigraphical sequences. This time interval therefore results from the overlapping error bars of ${ }^{87} \mathrm{Sr} /{ }^{86} \mathrm{Sr}$ values belonging to the directly underlying and overlying sequences. Diamond-shape ${ }^{87} \mathrm{Sr} /{ }^{86} \mathrm{Sr}$ data points refer to samples belonging to the earliest transgressive levels. Red-labelled FOR6 ${ }^{87} \mathrm{Sr} /{ }^{86} \mathrm{Sr}$ value underlines an inconsistent vertical stratigraphical succession (with a presumably reworked shell). Corresponding log sections of the ${ }^{87} \mathrm{Sr} /{ }^{86} \mathrm{Sr}$ data are shown in light-green for the external subalpine chains and dark-green for the Jura chain (see Fig. 1 for the localization of log sections). The two right-most columns correspond to the Miocene eustatic curve of Miller et al. (2005) and the corresponding geochronological calibration of the Gradstein et al. (2004) eustatic curve. Blue arrows show the eustatic sea-level rises depicted by Miller et al. (2005).

This article is protected by copyright. All rights reserved 
Fig. 13. Depositional models based on the Miocene marine successions of the southern Jura synclines and the subalpine massifs: FWWB = Fair-Weather Wave Base; SWWB = Storm-Weather Wave Base. (A) Wave-dominated depositional model. (B) Mixed wave-tide depositional model. (C) River to tidal dominated depositional model. (D) River-dominated Gilbert delta depositional model.

Fig. 14. Palaeo-landscape reconstructions based on the subcrop map of the basal Miocene disconformity. This map was created by reporting all stratigraphical contacts of the basal Miocene observed in the field in addition to those presented in the 1/50 000 geological maps (see BRGM website: http://infoterre.brgm.fr/). (A) Subcrop map in the southern Jura synclines, subalpine massifs and Bas-Dauphiné Basin area: (B) is an interpreted close-up focusing on the Southern Jura synclines area. (B) Subcrop map in the Southern Jura synclines showing east-west incised valleys at the western part of the area: (C) and (D) are reconstructed geological cross-sections preceding the Miocene marine transgression. (C) East-west reconstructed geological cross-section implying a $1^{\circ}$ gentle slope (dipping to the east), on which the Miocene sediments onlapped. (D) North-south reconstructed geological cross-section showing east-west incised valleys.

Fig. 15. Foreland basin system zonation (modified from DeCelles \& Giles, 1996).

Fig. 16. Prograding Gilbert delta foresets overlying braided river deposits in the proximal depozone (section 22, location in Fig. 1), involving an abrupt steepening of the slope controlled by tectonic activity coeval increase of seawater depth (eustatic-driven or flexural-driven, or both of them).

Fig. 17. Model of a vertical sedimentary succession during a third-order sequence in the distal depozone and its proximal depozone relative, with emphasis on the predominant hydrodynamic processes occurring during the transgressive and regressive system tracts. Legend as in Fig. 11A.

Fig. 18. Model dealing with the evolution of sedimentary processes changes during third-order infill sequences (of the overfilled phase) in peripheral foreland basins. These results are compared with the Rhodano-Provencal Molassic Basin (south-east France; Demarcq, 1962; Rubino et al., 1990; Crumeyrolle et al., 1991; Besson et al., 2002, 2005; James et al., 2014), the Ebron Basin (northern Spain; Anadón et al., 1986; Burns et al., 1997; López-Blanco et al., 2000; Cabello et al., 2010) and the Western Interior Seaway of North America or WISNA (Utah, United States; Plink-Björklund et

This article is protected by copyright. All rights reserved 
al., 2008; Plink-Björklund, 2012; Steel et al., 2012; Schwans, 1995; Van Wagoner, 1995; Yoshida et al., 2007).

Table 1. Summary of facies descriptions. Header lines introduce the five different depositional processes, and the last header lines corresponds to the facies of subaerial exposure and other noncategorized facies.

Table 2. ${ }^{87} \mathrm{Sr} /{ }^{86} \mathrm{Sr}$ values measured on shells (pectinids and oysters). According to McArthur et al. (2012), values have been normalized to the value of 0.710248 for the NBS987 standard, and uncertainties on the mean age correspond to the uncertainty, at 95\% confidence level, of the measurements (sample and corresponding NBS standards) added to the uncertainty on the ${ }^{87} \mathrm{Sr} /{ }^{86} \mathrm{Sr}$ marine curve (LOWESS version 5). Propagated uncertainties are shown as standard errors of the mean values.

This article is protected by copyright. All rights reserved 


\begin{tabular}{|c|c|c|c|c|c|c|c|}
\hline Facies & Lithology and texture & Bedding & Sedimentary structures & Biogenic components & Interpretation (depositional environment) & $\begin{array}{l}\text { Sedimentary } \\
\text { environments } \\
\text { and Facies } \\
\text { Association }\end{array}$ & Fig \\
\hline \multicolumn{8}{|c|}{ WAVE-DOMINATED } \\
\hline F1 & Blue-grey clayey-marls to silts & Massive & $\begin{array}{l}\text { Structureless. Local occurrence of } \\
\text { millimetre to centimetre-scale, } \\
\text { normally graded sandy levels. Locally } \\
\text { bioturbated (Planolites sp ichnofacies) }\end{array}$ & $\begin{array}{l}\text { Few benthic foraminifera, rare } \\
\text { planktonic foraminifera } \\
\text { (Globigerinoïdes trilobus and } \\
\text { Globoritalia acrostoma) and } \\
\text { ostracods }\end{array}$ & $\begin{array}{l}\text { Offshore zone: Foraminifera assemblages (water depth } \\
\text { of } 0 \text { to } 50 \mathrm{~m} \text { ), bioturbation, millimetre-thick distal } \\
\text { tempestites and absence of oscillation structures imply } \\
\text { an offshore environment }\end{array}$ & \multirow[b]{2}{*}{$\begin{array}{l}\text { Offshore: } \\
\text { FA1 }\end{array}$} & 4 \\
\hline F2 & Silts to very fine sands & Massive & $\begin{array}{l}\text { Structureless. Highly bioturbated } \\
\text { (Thalassinoides } s p \text { and Planolites } s p \\
\text { ichnofacies) }\end{array}$ & $\begin{array}{l}\text { Laterally continuous accumulation of } \\
\text { big-sized (decimetre) monospecific } \\
\text { bivalves (oysters or pectens) levels, } \\
\text { wood fragments, benthic foraminifera } \\
\text { and rare planktonic foraminifera, } \\
\text { ostracods and nannoplankton }\end{array}$ & $\begin{array}{l}\text { Offshore zone: Heavily bioturbated, planktonic } \\
\text { foraminifera and laterally continuous accumulation of } \\
\text { monospecific bivalve level (in situ, more likely for } \\
\text { pectens, suggesting reduced accumulation rates ; ex } \\
\text { situ, more likely for oysters, suggesting distal } \\
\text { tempestites) imply an offshore environment }\end{array}$ & & 2 \\
\hline F3 & $\begin{array}{l}\text { Silts to very fine sands / } \\
\text { moderate-sorted fine sands }\end{array}$ & $\begin{array}{l}\text { Pluri-decimetre } \\
\text { wavy beds. } \\
\text { Discontinuous } \\
\text { at metres to tens } \\
\text { of metre-scale }\end{array}$ & $\begin{array}{l}\text { Decimetre-thick hummocky cross- } \\
\text { stratifications (HCS) }\end{array}$ & None & $\begin{array}{l}\text { Offshore transition zone: Alternation of quiet water } \\
\text { deposits (fine-grained deposits) and oscillation } \\
\text { structures (HCS) imply storm activity in the offshore } \\
\text { transition environment between the SWWB and FWWZ }\end{array}$ & $\begin{array}{c}\text { Offshore } \\
\text { transition: } \\
\text { FA2 }\end{array}$ & 2 \\
\hline $\mathbf{F}$ & $\begin{array}{l}\text { Calcarenites (moderate sorting, } \\
\text { medium to very coarse sands, } \\
\text { sometimes rich in detrital } \\
\text { glauconite) }\end{array}$ & $\begin{array}{l}\text { Amalgamated } \\
\text { pluri-centimetre } \\
\text { to decimetre } \\
\text { wavy beds }\end{array}$ & $\begin{array}{l}\text { Centimetre to decimetre-scale } \\
\text { amalgamated oscillation structures } \\
\text { (HCS and wave ripples) }\end{array}$ & $\begin{array}{l}\text { Commonly abundant: Bryozoans, } \\
\text { bivalve fragments (mostly Pecten } \\
\text { Praescabriusculus), echinoid platelets } \\
\text { and spines, benthic foraminifera and } \\
\text { red algae. Occurrences of few } \\
\text { shark/fish teeth, corals and ostracods }\end{array}$ & $\begin{array}{l}\text { Shoreface zone: Amalgamated oscillation structures } \\
\text { (symmetrical ripples) imply continuous wave activity } \\
\text { above the FWWZ }\end{array}$ & $\begin{array}{l}\text { Shoreface: } \\
\text { FA3 }\end{array}$ & 2 \\
\hline F5 & $\begin{array}{l}\text { Well-sorted medium to very } \\
\text { coarse sands }\end{array}$ & Massive & $\begin{array}{l}\text { Prograding and retrograding pluri- } \\
\text { metre clinoforms. Plane-parallel to } \\
\text { low-angle stratifications. Antidunes. } \\
\text { Small-scale oblique tangential cross- } \\
\text { strata with downcutting in the } \\
\text { bottomsets. Mud clasts. Root traces }\end{array}$ & None & $\begin{array}{l}\text { Beach: Continuous high-energy currents (plane to low- } \\
\text { angle parallel stratifications) indicate wave swash and } \\
\text { backwash in the foreshore. Influence of tides is possible } \\
\text { by the occurrence of wave megaripples and mudclasts }\end{array}$ & $\begin{array}{l}\text { Foreshore: } \\
\text { FA4 }\end{array}$ & 3 \\
\hline
\end{tabular}

This article is protected by copyright. All rights reserved 


\begin{tabular}{|c|c|c|c|c|c|c|c|}
\hline & & & $\begin{array}{l}\text { (vertical or oblique, tube-like voids, } \\
\text { aligned below one well-marked } \\
\text { surface) }\end{array}$ & & & & \\
\hline F6 & $\begin{array}{l}\text { Clast-supported micro- } \\
\text { conglomerates to conglomerates. } \\
\text { Poorly sorted, well rounded } \\
\text { pebbles to cobbles, rarely } \\
\text { boulders (Cretaceous limestones, } \\
\text { cherts and radiolarites) }\end{array}$ & Massive & Bioperforated and imbricated pebbles & $\begin{array}{l}\text { Rich in pectens and oysters, } \\
\text { bryozoans, echinoderms and red algae }\end{array}$ & $\begin{array}{l}\text { Beach berm: Imbricated, bioperforated pebbles and } \\
\text { marine fauna indicates storm beach berms }\end{array}$ & & 3 \\
\hline \multicolumn{8}{|c|}{ MIXED WAVE-TIDE } \\
\hline F7 & $\begin{array}{l}\text { Clays to silts / well-sorted fine to } \\
\text { medium sands }\end{array}$ & $\begin{array}{l}\text { Alternation of } \\
\text { horizontal and } \\
\text { wavy } \\
\text { centimetre-beds }\end{array}$ & $\begin{array}{l}\text { Laterally continuous centimetre-thick } \\
\text { mudstone laminae (fluid mud). } \\
\text { Millmetre to centimetre-thick sandy } \\
\text { lenses (lenticular bedding) formed by } \\
\text { combined-flow ripples. Unidirectional } \\
\text { foreset laminae are draped by mud } \\
\text { deposits. Locally bioturbated } \\
\text { (Cosmoraphe sp.) }\end{array}$ & None & $\begin{array}{l}\text { Distal open-coast subtidal: Laterally constant (thick) } \\
\text { mudstone laminae, occurrence of combined-flow } \\
\text { structures imply wave (-tide) and/or storm activity in } \\
\text { the offshore transition environment. Mud drapes in the } \\
\text { bottomsets indicate a tidal influence }\end{array}$ & \multirow{2}{*}{$\begin{array}{c}\text { Open-coast } \\
\text { subtidal: FA5 }\end{array}$} & 4 \\
\hline & $\begin{array}{l}\text { Clays to silts / well-sorted fine to } \\
\text { medium sands }\end{array}$ & 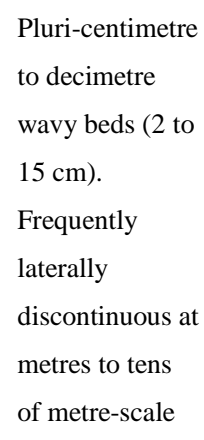 & $\begin{array}{l}\text { Alternation of centimetre-thick } \\
\text { mudstone laminae (fluid mud) and } \\
\text { centimetre to decimetre sandy layers } \\
\text { (wavy bedding, mud/sand ratio, } \\
\text { repetitively, varies) with dominance } \\
\text { of combined-flow ripples. Locally } \\
\text { bioturbated (Thalassinoides sp } \\
\text { ichnofacies) }\end{array}$ & None & $\begin{array}{l}\text { Proximal open-coast subtidal: Alternation of quiet } \\
\text { water deposits and combined-flow structures imply } \\
\text { wave (-tide) and/or storm activity in the offshore } \\
\text { transition zone. Internal architecture of the ripples } \\
\text { showing unidirectional current, foreset laminae (which } \\
\text { are draped by muddy deposits) and the pervasive } \\
\text { mud/sand ratio variability indicate a tidal influence }\end{array}$ & & 4 \\
\hline F & $\begin{array}{l}\text { Very well-sorted fine to medium } \\
\text { sands }\end{array}$ & Massive & $\begin{array}{l}\text { Flaser bedding. Sharp base of the unit, } \\
\text { underlined by rare gutter casts }\end{array}$ & Wood fragments & $\begin{array}{l}\text { Open-coast sand flat: Gutter casts indicate storm } \\
\text { influence. Occurrence of flaser bedding suggests quiet- } \\
\text { water deposits, probably tidal in origin. Stratigraphic } \\
\text { position above F7 and F8 suggests a similar mixed- } \\
\text { energy coastal environment }\end{array}$ & $\begin{array}{c}\text { Open-coast } \\
\text { intertidal: } \\
\text { FA6 }\end{array}$ & 5 \\
\hline
\end{tabular}

This article is protected by copyright. All rights reserved 
Well-sorted fine to medium sands / silts to very fine sands

\section{Pluri-decimetre}

to metre

Laterally

discontinuous at

metres to tens

of metre-scale horizontal beds.
In the sandstones, plane-parallel

laminations pass vertically to

symmetrical ripples (SCS/HCS).

Sandstones pass laterally to finer-

grained deposits with

interstratification of combined-flow

ripples, commonly displaying oblique

foresets with downcutting in their

bottomsets
None

Ridges and runnels: Lateral changes from sandstones to heterolithic facies dominated by wave structures (highenergy currents) and frequent occurrence of combinedflow ripples with downcutting in the bottomsets of the ripples (thus suggesting a tide modulation), imply a 'ridge and runnel' foreshore environment

\section{TIDE-DOMINATED}

Oblique tangential cross-beds ( 2 to 5

$\mathrm{m})$ associated in the orthogonal

Discontinuous section to trough cross-beds (5 to 10

Moderately-sorted fine to

at tens to

medium sands

hundreds of

$\mathrm{m})$. Repetitive variability in the

thickness and competence (proportion

of fine-grained deposits) of cross-

laminae. Mud drapes (flaser to wavy

bedding) in the bottomsets

Oblique tangential cross-beds (1 to 3

$\mathrm{m}$ ) associated in the orthogonal

section to trough cross-beds (5 to 10

$\mathrm{m})$. Repetitive variability in the

thickness of cross-laminae. Mud

drapes (flaser bedding) in the

bottomsets. Occurrence of metre-sized

sigmoid-shaped cross-strata

Oblique tangential cross-beds (pluri-

decimetre to $1 \mathrm{~m}$ ) associated in the

orthogonal section to trough cross-

Discontinuous

at metres to ten

beds (1 to $3 \mathrm{~m}$ ). Thin mud and organic

matter drapes in the bottomsets,

locally as double mud drapes. Thin,

discontinuous conglomeratic levels
None

Large tidal dunes: Fine-grained deposits in the

bottomsets, repetitive variability in the thickness of

cross-laminae (tidal bundles) and large-scale cross-

strata interstratified within offshore facies (F1 and F2)

indicate a deep subtidal zone

Medium tidal dunes: Sigmoid-shaped cross-strata and repetitive variability in the thickness of cross-laminae corresponding to tidal bundles. Metre-scale cross-beds and poorly-sorted medium to very coarse sands or calcarenites rich in bivalves suggest an intermediate subtidal zone

Small tidal dunes: Double mud drapes correspond to low and high tide slack-water deposits (daily tidal cyclicity) in a subtidal zone. Discontinuous conglomeratic levels suggest fluvial inputs that indicate a proximal shallow subtidal zone
Subtidal:

This article is protected by copyright. All rights reserved 


\begin{tabular}{|c|c|c|c|c|c|c|c|}
\hline & & & $\begin{array}{l}\text { locally underline the cross- } \\
\text { stratifications }\end{array}$ & & & & \\
\hline F14 & $\begin{array}{l}\text { Poorly-sorted coarse to very } \\
\text { coarse sands / clays to silts }\end{array}$ & $\begin{array}{l}\text { Discontinuous } \\
\text { at tens to } \\
\text { hundreds of } \\
\text { metre-scale }\end{array}$ & $\begin{array}{l}\text { Incisions of } 5 \text { to } 15 \mathrm{~m} \text { deep and pluri- } \\
\text { decametre wide. Very large-scale, } \\
\text { low-angle inclined surfaces (tens of } \\
\text { metres wide) which are erosive } \\
\text { (covered by bioclasts, pebbles and } \\
\text { mud clasts), filled by decimetre to } \\
\text { metre-scale bi-directional cross-beds } \\
\text { with flaser beddings or by pluri } \\
\text { decimetre-thick alternations of flaser- } \\
\text { to wavy bedding with bi-directional } \\
\text { ripples and load casts }\end{array}$ & $\begin{array}{l}\text { May contain shells (sometimes in a } \\
\text { high proportion, mostly pectens and } \\
\text { oysters), especially upon the erosive } \\
\text { lag }\end{array}$ & $\begin{array}{l}\text { Tidal channel: Deep and wide incision infilled by tidal } \\
\text { deposits (flaser to wavy bedding and bi-directional } \\
\text { cross-beds) correspond to a tidal channel infill in a } \\
\text { subtidal zone. Low-angle internal oblique organization } \\
\text { correspond to lateral accretion in meandering tidal } \\
\text { channels }\end{array}$ & & 6 \\
\hline 15 & $\begin{array}{l}\text { Well-sorted medium to coarse } \\
\text { sands }\end{array}$ & Massive & $\begin{array}{l}\text { Oblique tangential cross-beds (pluri- } \\
\text { decimetre to metre-scale) associated } \\
\text { in the orthogonal section to trough } \\
\text { cross-beds (pluri-metre scale). } \\
\text { Symmetrical to asymmetrical ripples } \\
\text { (locally bi-directional) with an } \\
\text { overlying thin mud or silt drape in the } \\
\text { bottomsets of the cross-beds }\end{array}$ & Rare bioclastic levels & $\begin{array}{l}\text { Sand flat: Small-scale dunes/megaripples and opposite- } \\
\text { directed current ripples in bottomsets suggest tidal } \\
\text { dunes. Symmetrical ripples in the bottomsets } \\
\text { correspond to (ripple) festoons localized in the inter- } \\
\text { dune trough, indicating water run-off during falling tide } \\
\text { in the intertidal zone }\end{array}$ & \multirow{3}{*}{$\begin{array}{l}\text { Intertidal: } \\
\text { FA8 }\end{array}$} & 7 \\
\hline F16 & $\begin{array}{l}\text { Silts and muds / well-sorted very } \\
\text { fine sands to fine sands }\end{array}$ & Massive & $\begin{array}{l}\text { Bi-directional asymmetrical ripples. } \\
\text { Loadcasts. Millimetre to centimetre- } \\
\text { scale rill marks }\end{array}$ & None & $\begin{array}{l}\text { Mixed flat: Bi-directional asymmetrical ripples suggest } \\
\text { tidal currents in a low to moderate energy zone. Rill } \\
\text { marks correspond to water run-off during falling tide in } \\
\text { the intertidal zone }\end{array}$ & & 7 \\
\hline F17 & Well-sorted fine to medium sands & $\begin{array}{l}\text { Discontinuous } \\
\text { at metres to tens } \\
\text { of mere-scale }\end{array}$ & $\begin{array}{l}\text { Incisions of } 1 \text { to } 5 \mathrm{~m} \text { deep and } 5 \text { to } 10 \\
\mathrm{~m} \text { wide infilled by horizontal or } \\
\text { oblique stratified sandstones, locally } \\
\text { with abundant mudclasts. Angular } \\
\text { mudclasts at the base of the incision }\end{array}$ & Very rare bioclasts on the erosive lag & $\begin{array}{l}\text { Tidal creeks: Small-scale channels always } \\
\text { interstratified with F15 sandflat facies or F16 mixed-flat } \\
\text { facies that indicate an intertidal zone }\end{array}$ & & 7 \\
\hline \multicolumn{7}{|c|}{ MIXED RIVER-TIDE } & \\
\hline F18 & Moderately-sorted medium to & Massive & Trough cross-beds (pluri-metre to & Wood fragments & River mouth: Sandy dominated facies displaying small- & River to tidal & 8 \\
\hline
\end{tabular}

This article is protected by copyright. All rights reserved 


\begin{tabular}{|c|c|c|c|c|c|c|}
\hline $\begin{array}{l}\text { coarse sands / clast-supported } \\
\text { conglomerates. Well-rounded } \\
\text { and poorly sorted pebbles to } \\
\text { cobbles (mostly cretaceous } \\
\text { limestones, rare polygenic clasts) }\end{array}$ & & $\begin{array}{l}\text { decametre) with locally pluri- } \\
\text { decimetre oblique tangential cross- } \\
\text { beds (North-South) with wood } \\
\text { fragments in the foresets. Occurrence } \\
\text { of asymmetrical ripples on the trough } \\
\text { or oblique tangential cross-beds. } \\
\text { Conglomerates found as laterally } \\
\text { continuous levels interstratified within } \\
\text { the sandstones, or as oriented pebbles } \\
\text { to cobbles emphasizing the cross- } \\
\text { stratifications. Locally imbricated } \\
\text { pebbles/cobbles (east to west). Local } \\
\text { erosion surfaces forming gutters less } \\
\text { than } 3 \text { m deep and few m wide infilled } \\
\text { by oblique tangential cross- } \\
\text { stratifications. High concentration of } \\
\text { centimetre-angular mudclasts locally } \\
\text { found in the sandstone levels }\end{array}$ & & $\begin{array}{l}\text { scale cross-beds (north-south = seaward-axis) with } \\
\text { opposite-directed asymmetrical ripples suggest tidal } \\
\text { currents. Conglomeratic levels, pebble/cobble } \\
\text { imbrications) and gutters (east = Alps; to west =palaeo- } \\
\text { sea indicate riverine inputs }\end{array}$ & $\begin{array}{l}\text { transition: } \\
\text { FA9 }\end{array}$ & \\
\hline \multicolumn{6}{|c|}{ RIVER-DOMINATED } & \\
\hline $\begin{array}{l}\text { Clast-supported conglomerates. } \\
\text { Moderately sorted well-rounded } \\
\text { pebbles, cobbles and boulders } \\
\text { (mostly cretaceous limestones, } \\
\text { rare polygenic clasts) }\end{array}$ & Massive & $\begin{array}{l}\text { Stack of pluri-decimetre to metre- } \\
\text { scale sheet levels of various grain } \\
\text { sizes, frequently imbricated (east to } \\
\text { west). Low-angle pluri-metre trough } \\
\text { cross-beds. Pluri-metre sandstone } \\
\text { lenses. Occurrence of normally- } \\
\text { graded levels. At the base of the unit, } \\
\text { pluri-metre erosional surfaces, infilled } \\
\text { by oblique tangential stratified } \\
\text { conglomerates. Mud deposits } \\
\text { (laterally discontinuous at metres to } \\
\text { tens of metre-scale) with lignite levels } \\
\text { are interstratified }\end{array}$ & $\begin{array}{l}\text { Micro-mammals in the muddy } \\
\text { deposits }\end{array}$ & $\begin{array}{l}\text { Braided-river system: Massive horizontal stratonomy, } \\
\text { clast-supported conglomerates with pebble/cobble } \\
\text { imbrications (east = Alps; to west = palaeo-sea), low- } \\
\text { angle pluri-metre trough cross-beds that imply the } \\
\text { progradation of braided bars during floods (and } \\
\text { sandstone lenses corresponding to locally preserved } \\
\text { finer deposits onto the bars, or in the deactivated } \\
\text { channels between the fluvial bars) suggest a braided- } \\
\text { river system }\end{array}$ & $\begin{array}{c}\text { River } \\
\text { environment: } \\
\text { FA10 }\end{array}$ & \\
\hline
\end{tabular}

This article is protected by copyright. All rights reserved 


\begin{tabular}{|c|c|c|c|c|c|c|c|}
\hline F20 & $\begin{array}{l}\text { Coarse sandy matrix-supported } \\
\text { conglomerates. Poorly sorted, } \\
\text { well-rounded pebbles to cobbles } \\
\text { (mostly cretaceous limestones, } \\
\text { rare polygenic clasts) }\end{array}$ & Massive & $\begin{array}{l}\text { Large-scale tangential cross-beds ( } 15 \\
\text { to } 30 \mathrm{~m} \text { ) dipping at } 20 \text { to } 30^{\circ} \text {. Rare } \\
\text { slumps at pluri-metre to tens of metre- } \\
\text { scale. Rare bioperforated pebbles }\end{array}$ & None & $\begin{array}{l}\text { Gilbert delta foresets: Poorly sorted, matrix-supported } \\
\text { conglomerates suggest debris-flow deposits after a } \\
\text { rather long-distance transport induced by a fluvial } \\
\text { system (well-rounded clasts originating from the Alps } \\
\text { eastwards). Pluri-decametre foresets correspond to the } \\
\text { progradation of a river-dominated delta }\end{array}$ & \multirow{2}{*}{$\begin{array}{c}\text { Gilbert delta } \\
\text { : FA11 }\end{array}$} & 10 \\
\hline F2 & $\begin{array}{l}\text { Blue-grey clayey-marls to silts / } \\
\text { clast-supported conglomerates. } \\
\text { Poorly sorted, well-rounded } \\
\text { pebbles to cobbles (limestones of } \\
\text { Cretaceous age, rarely cherts and } \\
\text { radiolarites) }\end{array}$ & Massive & $\begin{array}{l}10 \text { to } 15 \mathrm{~cm} \text { thick conglomeratic } \\
\text { levels interstratified in muddy } \\
\text { deposits }\end{array}$ & $\begin{array}{l}\text { Few benthic foraminifera, rare } \\
\text { planktonic foraminifera } \\
\text { (Globigerinoïdes trilobus and } \\
\text { Globoritalia acrostoma) and } \\
\text { ostracods }\end{array}$ & $\begin{array}{l}\text { Gilbert delta bottomsets: Interstratification of } \\
\text { conglomeratic levels in the offshore F1 deposits } \\
\text { corresponds to the bottomsets of a river-dominated } \\
\text { delta }\end{array}$ & & 10 \\
\hline \multicolumn{8}{|c|}{ SUBAERIAL EXPOSURE } \\
\hline F22 & Red to orange mud to fine sands & $\begin{array}{l}\text { Discontinuous } \\
\text { at metre to tens } \\
\text { of metre-scale }\end{array}$ & Rootlets & None & $\begin{array}{l}\text { Palaeosoil or pedogenesis level: Rootlets, and reddish } \\
\text { sandy levels suggesting organic matter oxidation, imply } \\
\text { subaerial exposure }\end{array}$ & Palaeosoil & 9 \\
\hline$F_{2}$ & $\begin{array}{l}\text { Limestone with quartz grains and } \\
\text { lithic exotic clasts / light grey } \\
\text { marls }\end{array}$ & $\begin{array}{l}\text { Laterally } \\
\text { continuous }\end{array}$ & $\begin{array}{l}\text { Calcareous level contain tubular } \\
\text { vertical structures with an irregular } \\
\text { surface at its top. Pass laterally to } \\
\text { light grey marls }\end{array}$ & Fresh-water fauna in light grey marls & $\begin{array}{l}\text { Calcretes: Calcareous level associated laterally to light } \\
\text { grey marls with palustrine to sub-lacustrine fauna } \\
\text { indicate a subaerial exposure }\end{array}$ & Calcrete & \\
\hline \multicolumn{8}{|c|}{ NON-CATEGORIZED } \\
\hline F24 & $\begin{array}{l}\text { Matrix-supported micro- } \\
\text { conglomerates to conglomerates } \\
\text { (rarely clast-supported). Poorly } \\
\text { sorted, moderate to poorly } \\
\text { rounded pebbles, cobbles and } \\
\text { rare boulders (limestones of } \\
\text { Cretaceous age, rarely cherts and } \\
\text { radiolarites) }\end{array}$ & $\begin{array}{l}\text { Laterally } \\
\text { discontinuous } \\
\text { units at } \\
\text { hundreds of } \\
\text { metres to } \\
\text { kilometre-scale }\end{array}$ & $\begin{array}{l}\text { Locally imbricated pebbles. Clasts are } \\
\text { rarely covered by glauconite coatings }\end{array}$ & None & $\begin{array}{l}\text { Transgressive lag: This facies characterizes the basal } \\
\text { Miocene sediments above the discordance. Poorly } \\
\text { sorted clasts, Cretaceous in age, correspond to local } \\
\text { sedimentary material reworked during the Miocene } \\
\text { transgression }\end{array}$ & $\begin{array}{c}\text { Transgressive } \\
\text { lag }\end{array}$ & \\
\hline F25 & $\begin{array}{l}\text { Fine-grained matrix-supported } \\
\text { centimetre to pluri-metre angular, } \\
\text { monogenic sandy clasts }\end{array}$ & $\begin{array}{l}\text { Laterally } \\
\text { continuous units } \\
\text { at tens of } \\
\text { kilometre-scale }\end{array}$ & $\begin{array}{l}\text { Ball and pillow structures. Clasts are } \\
\text { totally disorganized. They are } \\
\text { monogenic and often present } \\
\text { preserved stratification (e.g. tidal flat }\end{array}$ & None & $\begin{array}{l}\text { Earthquake-disturbed layer: Ball and pillow structures, } \\
\text { disorganized monogenic clasts (centimetre to pluri- } \\
\text { metre) indicate strong disturbance events (i.e. seismites) }\end{array}$ & $\begin{array}{l}\text { Earthquake- } \\
\text { disturbed } \\
\text { layer }\end{array}$ & 10 \\
\hline
\end{tabular}

This article is protected by copyright. All rights reserved 
Sequence stratigraphy:

\begin{tabular}{|c|c|c|c|c|c|c|}
\hline $\begin{array}{c}\text { Log section } \\
\text { (Locality in Fig. 1) }\end{array}$ & ${ }^{87} \mathrm{Sr} /{ }^{86} \mathrm{Sr}$ & \pm & Mean age & \pm & $\begin{array}{c}\mathrm{T}=\text { Transgression } ; \mathrm{R}= \\
\text { Regression; } \mathrm{MF}= \\
\text { Maximum Flooding }\end{array}$ & $\begin{array}{c}\text { Third-order } \\
\text { sequence }\end{array}$ \\
\hline \multirow{5}{*}{ Génissiat (n¹) } & 0.708487 & 0.000040 & 19.00 & 0.55 & $\mathrm{R}$. & \multirow{5}{*}{ S1 } \\
\hline & 0.708421 & 0.000041 & 20.00 & 0.75 & & \\
\hline & 0.708399 & 0.000043 & 20.375 & 0.825 & 1. & \\
\hline & 0.708356 & 0.000006 & 21.15 & 0.15 & \multirow{2}{*}{ Early $\mathrm{T}$. } & \\
\hline & 0.708345 & 0.000006 & 21.35 & 0.15 & & \\
\hline Val de Fier $\left(n^{\circ} 2\right)$ & 0.708473 & 0.000021 & 19.15 & 0.30 & $\mathrm{R}$. & S1 \\
\hline \multirow{2}{*}{ Alby/s Chéran (n³) } & 0.708448 & 0.000025 & 19.55 & 0.40 & \multirow{2}{*}{$\mathrm{T}$. } & \multirow{2}{*}{ S1 } \\
\hline & 0.708388 & 0.000017 & 20.55 & 0.40 & & \\
\hline \multirow{6}{*}{ Gresy $\left(n^{\circ} 4\right)$} & 0.708635 & 0.000011 & 17.20 & 0.15 & \multirow{3}{*}{ MF. } & \multirow{4}{*}{ S2 } \\
\hline & 0.708611 & 0.000016 & 17.50 & 0.20 & & \\
\hline & 0.708618 & 0.000017 & 17.425 & 0.225 & & \\
\hline & 0.708627 & 0.000022 & 17.325 & 0.275 & $\mathrm{~T}$. & \\
\hline & 0.708381 & 0.000029 & 20.65 & 0.60 & \multirow{2}{*}{ Early $\mathrm{T}$. } & \multirow{2}{*}{$\mathrm{S} 1$} \\
\hline & 0.708338 & 0.000017 & 21.45 & 0.30 & & \\
\hline \multirow{7}{*}{ Forezan $\left(n^{\circ} 5\right)$} & 0.708696 & 0.000021 & 16.30 & 0.30 & \multirow{3}{*}{ Early $\mathrm{T}$. } & \multirow{3}{*}{ S3 } \\
\hline & 0.708705 & 0.000020 & 16.25 & 0.30 & & \\
\hline & 0.708641 & 0.000021 & 17.125 & 0.275 & & \\
\hline & 0.708633 & 0.000021 & 17.225 & 0.275 & Forly $\mathrm{P}$ & \multirow{4}{*}{ S2 } \\
\hline & 0.708648 & 0.000040 & 17.025 & 0.525 & 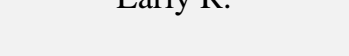 & \\
\hline & 0.708575 & 0.000029 & 17.95 & 0.35 & F $\mathrm{T}$ & \\
\hline & 0.708576 & 0.000020 & 17.95 & 0.25 & Larry & \\
\hline \multirow{2}{*}{ St-Sulpice (5b) } & 0.708419 & 0.000015 & 19.975 & 0.325 & \multirow{2}{*}{ Early $\mathrm{T}$. } & \multirow{2}{*}{ S1 } \\
\hline & 0.708402 & 0.000018 & 20.30 & 0.40 & & \\
\hline \multirow{3}{*}{ St-Jean-de-Couz $\left(n^{\circ} 6\right)$} & 0.708545 & 0.000011 & 18.30 & 0.15 & R. & \multirow{3}{*}{ S1 } \\
\hline & 0.708416 & 0.000013 & 20.025 & 0.275 & $T$ & \\
\hline & 0.708361 & 0.000017 & 21.05 & 0.35 & & \\
\hline \multirow{2}{*}{ Fontanil $\left(\mathrm{n}^{\circ} 10\right)$} & 0.708517 & 0.000041 & 18.65 & 0.50 & \multirow{2}{*}{$\mathrm{R}$. } & \multirow{2}{*}{ S1 } \\
\hline & 0.708436 & 0.000025 & 19.70 & 0.45 & & \\
\hline \multirow{4}{*}{ Loisieux $\left(\mathrm{n}^{\circ} 13\right)$} & 0.708690 & 0.000023 & 16.45 & 0.35 & \multirow{4}{*}{ Early $\mathrm{T}$. } & \multirow{4}{*}{ S3 } \\
\hline & 0.708712 & 0.000028 & 16.15 & 0.40 & & \\
\hline & 0.708671 & 0.000005 & 16.725 & 0.075 & & \\
\hline & 0.708692 & 0.000021 & 16.45 & 0.30 & & \\
\hline
\end{tabular}

This article is protected by copyright. All rights reserved 


\begin{tabular}{|c|c|c|c|c|c|c|}
\hline & 0.708687 & 0.000025 & 16.50 & 0.35 & & \\
\hline & 0.708586 & 0.000043 & 17.825 & 0.525 & \multirow{3}{*}{ Early $\mathrm{T}$. } & \multirow{3}{*}{$\mathrm{S} 2$} \\
\hline & 0.708610 & 0.000028 & 17.525 & 0.375 & & \\
\hline & 0.708615 & 0.000024 & 17.45 & 0.30 & & \\
\hline Dullin $\left(\mathrm{n}^{\circ} 14\right)$ & 0.708573 & 0.000025 & 17.975 & 0.275 & Early $\mathrm{T}$. & S2 \\
\hline \multirow{2}{*}{ Aiguebelette $\left(n^{\circ} 15\right)$} & 0.708395 & 0.000021 & 20.40 & 0.45 & \multirow{2}{*}{ Early $\mathrm{T}$. } & \multirow{2}{*}{$\mathrm{S} 1$} \\
\hline & 0.708347 & 0.000026 & 21.275 & 0.525 & & \\
\hline Chailles E (nº 16$)$ & 0.708653 & 0.000023 & 16.95 & 0.30 & Early R. & S2 \\
\hline \multirow{2}{*}{ Les Echelles $\left(\mathrm{n}^{\circ} 17\right)$} & 0.708563 & 0.000025 & 18.10 & 0.30 & \multirow{2}{*}{ Early $\mathrm{T}$. } & \multirow{2}{*}{$\mathrm{S} 2$} \\
\hline & 0.708536 & 0.000024 & 18.40 & 0.30 & & \\
\hline \multirow{3}{*}{ La Roize $\left(\mathrm{n}^{\circ} 20\right)$} & 0.708628 & 0.000015 & 17.30 & 0.20 & \multirow{3}{*}{ Early R. } & \multirow{3}{*}{$\mathrm{S} 2$} \\
\hline & 0.708621 & 0.000017 & 17.375 & 0.225 & & \\
\hline & 0.708640 & 0.000009 & 17.125 & 0.125 & & \\
\hline \multirow{2}{*}{ La Gachetière $\left(n^{\circ} 21\right)$} & 0.708626 & 0.000017 & 17.325 & 0.225 & MF. & S2 \\
\hline & 0.708625 & 0.000020 & 17.325 & 0.275 & $\mathrm{~T}$. & S2 \\
\hline \multirow{2}{*}{ Roche rousse $\left(\mathrm{n}^{\circ} 23\right)$} & 0.708685 & 0.000018 & 16.50 & 0.25 & Early T. & S3 \\
\hline & 0.708628 & 0.000031 & 17.30 & 0.40 & Early T. & S2 \\
\hline Magnieu $\left(\mathrm{n}^{\circ} 24\right)$ & 0.708566 & 0.000027 & 18.075 & 0.325 & Early $\mathrm{T}$. & S2 \\
\hline Chailles W $\left(n^{\circ} 27\right)$ & 0.708611 & 0.000029 & 17.525 & 0.375 & $\mathrm{~T}$. & S2 \\
\hline \multirow{3}{*}{ La Motte Fanjas ( $\left.n^{\circ} 33\right)$} & 0.708693 & 0.000044 & 16.40 & 0.60 & Early $\mathrm{T}$. & S3 \\
\hline & 0.708631 & 0.000043 & 17.25 & 0.55 & $\mathrm{~T}$. & S2 \\
\hline & 0.708592 & 0.000022 & 17.75 & 0.30 & Early T. & $\mathrm{S} 2$ \\
\hline \multirow{2}{*}{ St-Jean-en-Royans $\left(n^{\circ} 34\right)$} & 0.708723 & 0.000017 & 15.975 & 0.225 & Early T. & S3 \\
\hline & 0.708671 & 0.000017 & 16.70 & 0.25 & Late R. & S2 \\
\hline Oriol-en-Royans $\left(\mathrm{n}^{\circ} 35\right)$ & 0.708608 & 0.000016 & 17.55 & 0.20 & Early T. & S2 \\
\hline
\end{tabular}

This article is protected by copyright. All rights reserved 


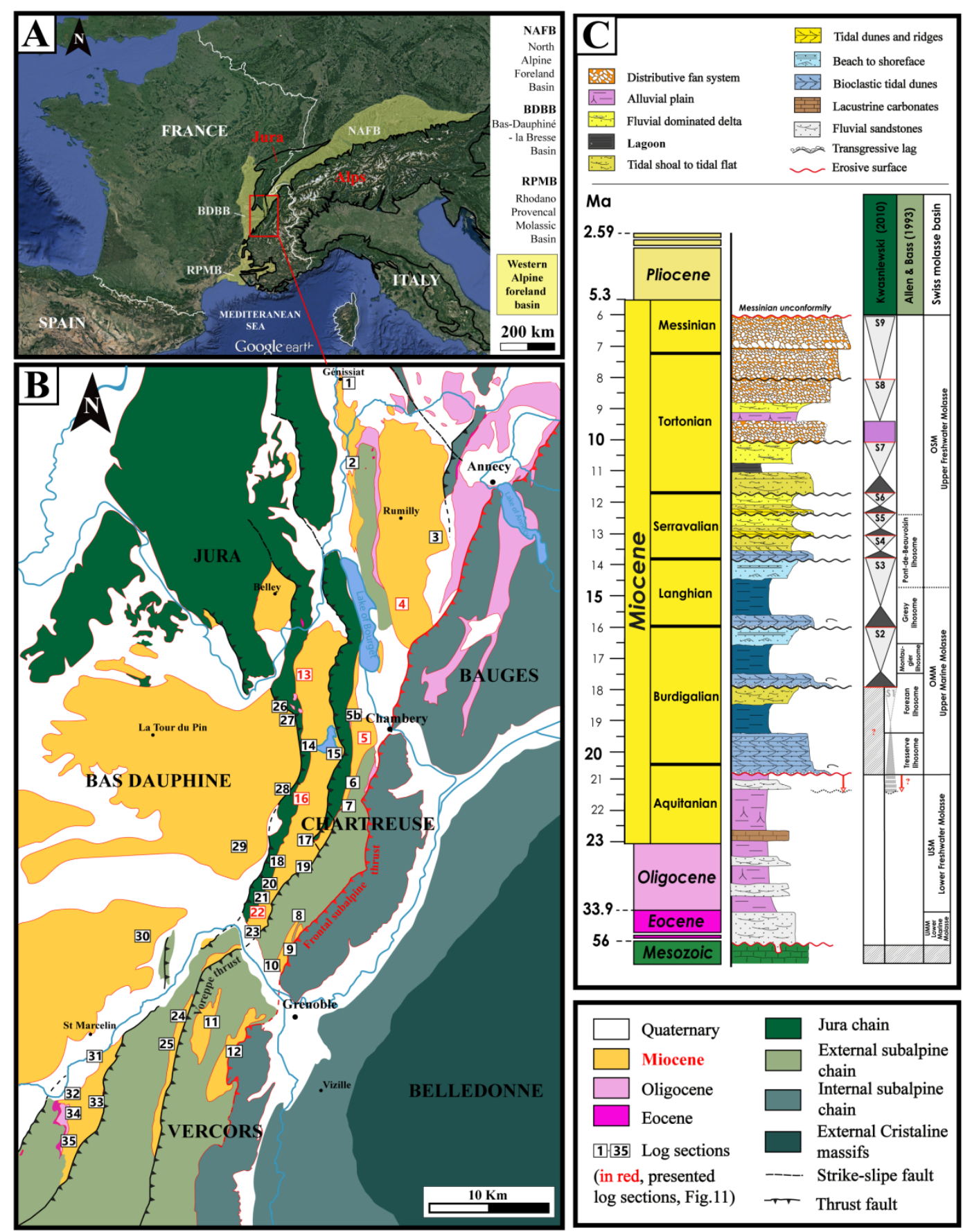

sed_12708_f1.tif 

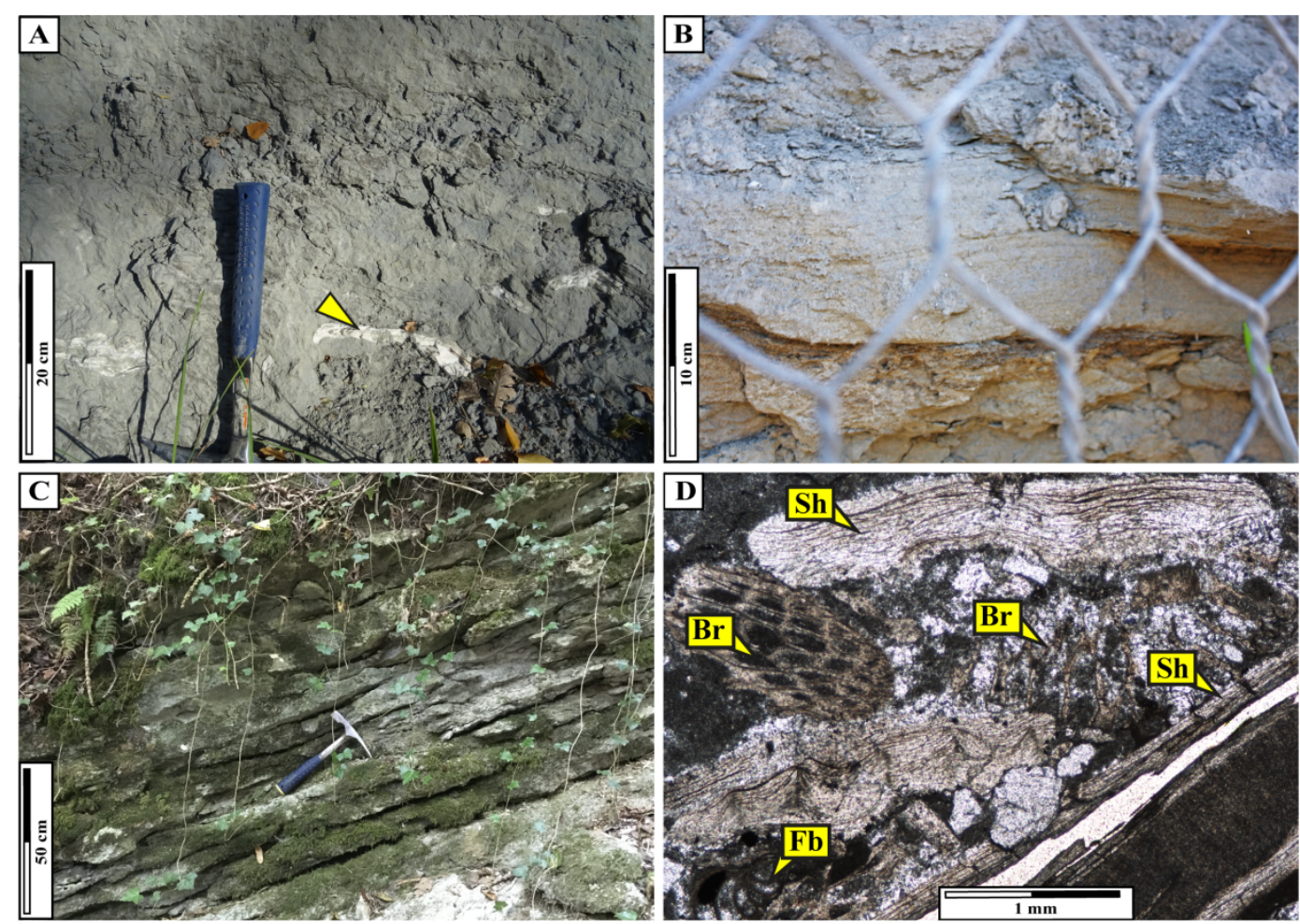

sed_12708_f2.tif

This article is protected by copyright. All rights reserved 

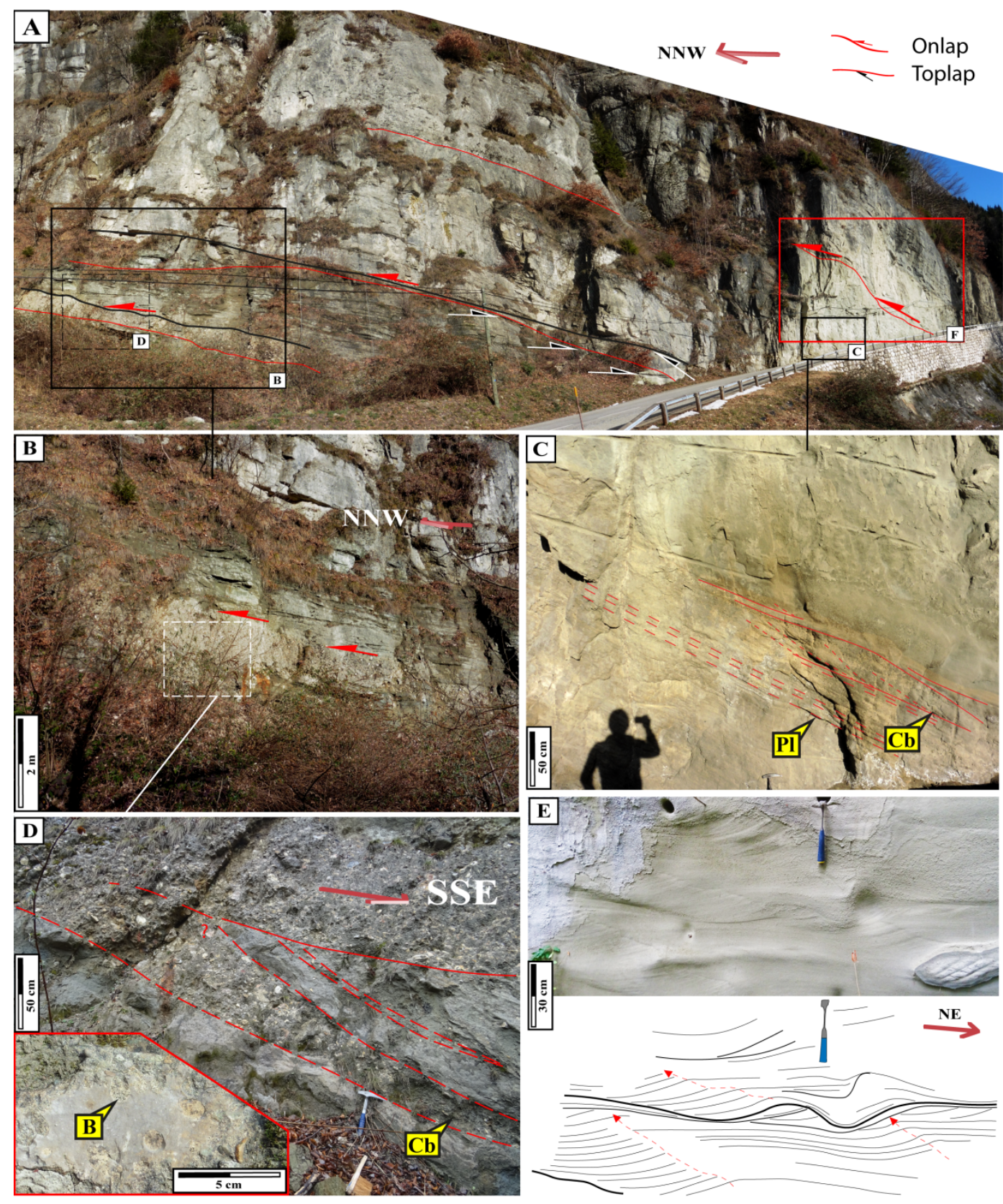

sed_12708_f3a.tif 

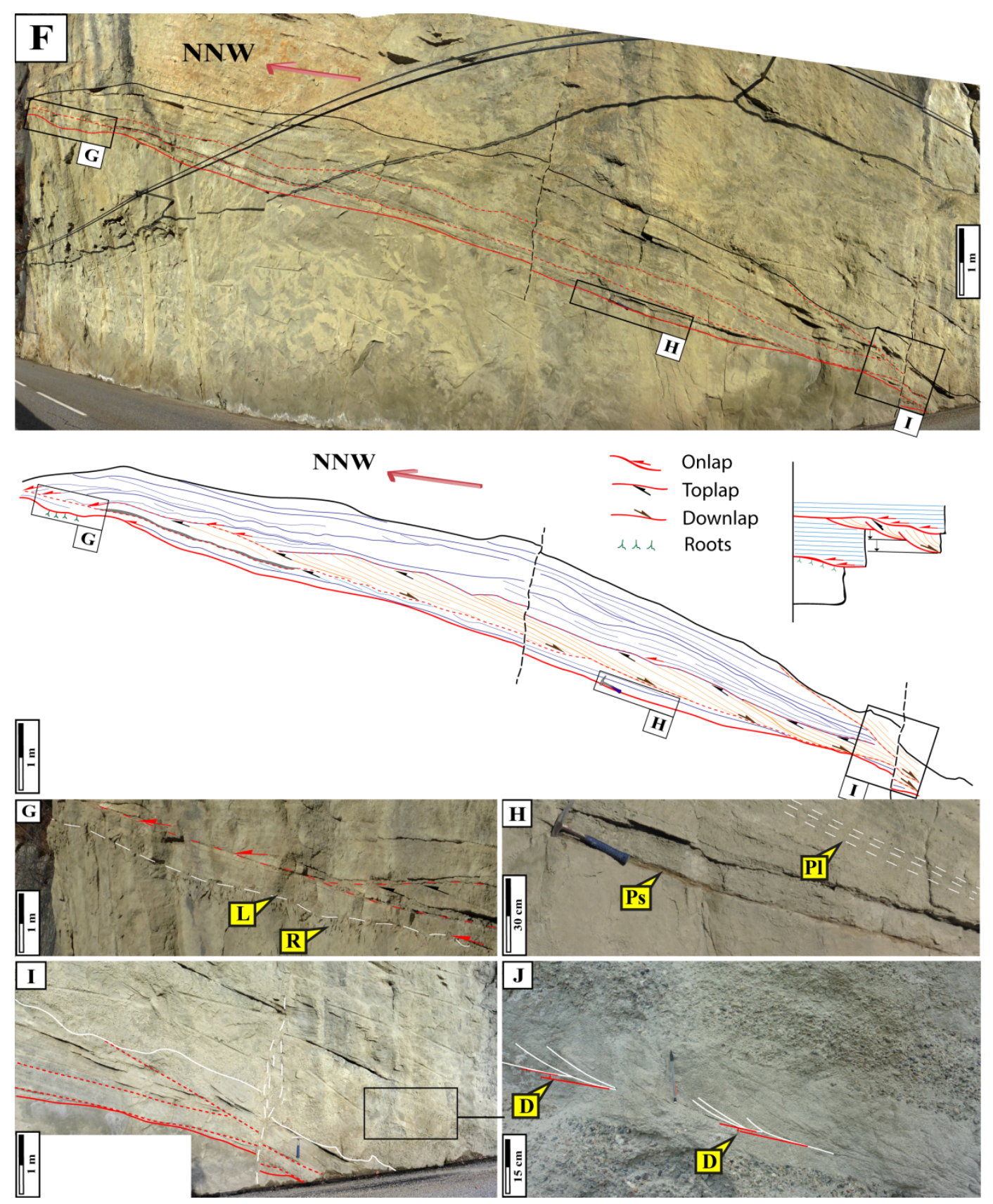

sed_12708_f3b.tif 

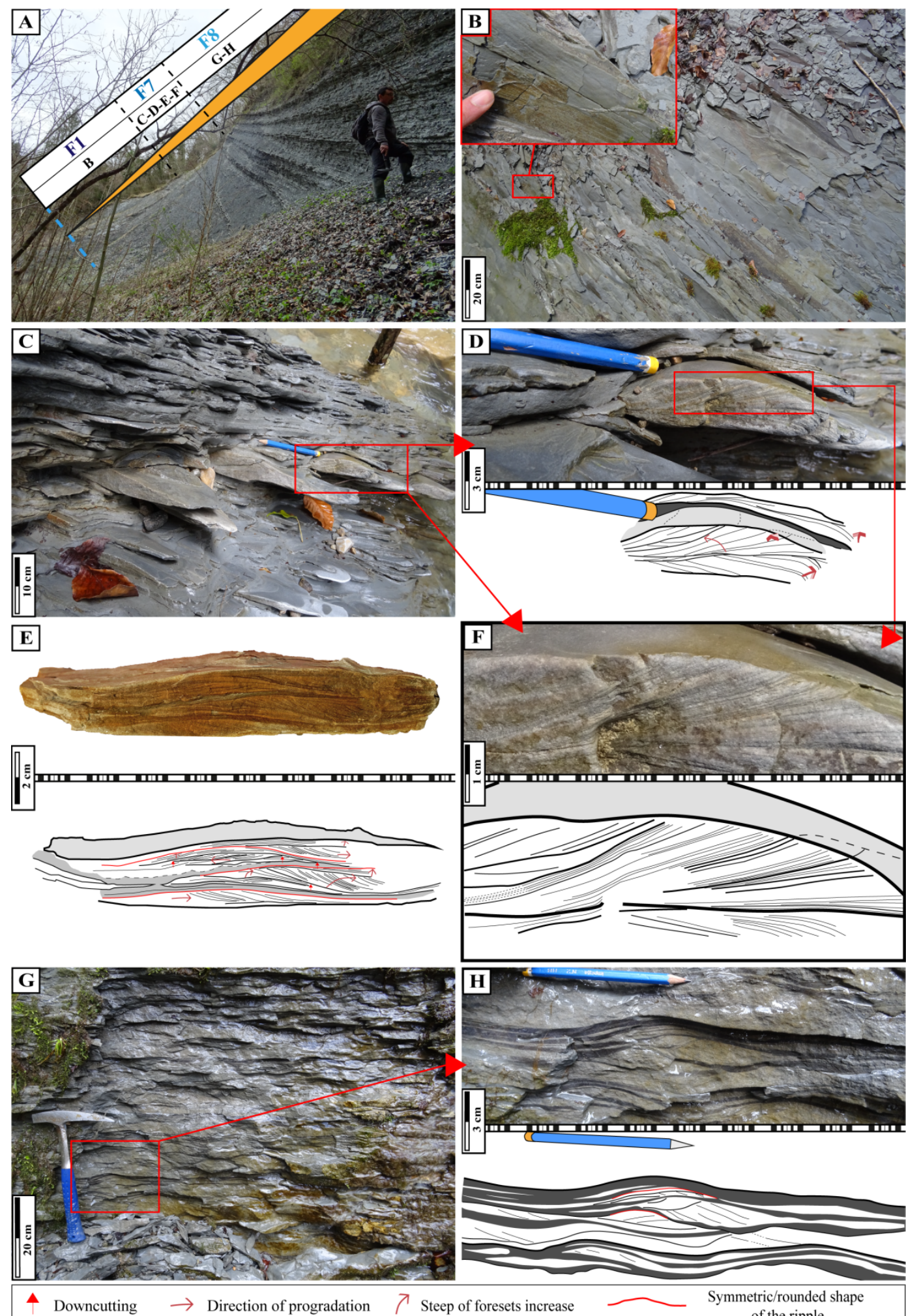

Symmetric/rounded shape of the ripple

$$
\text { sed_12708_f4.tif }
$$

This article is protected by copyright. All rights reserved 

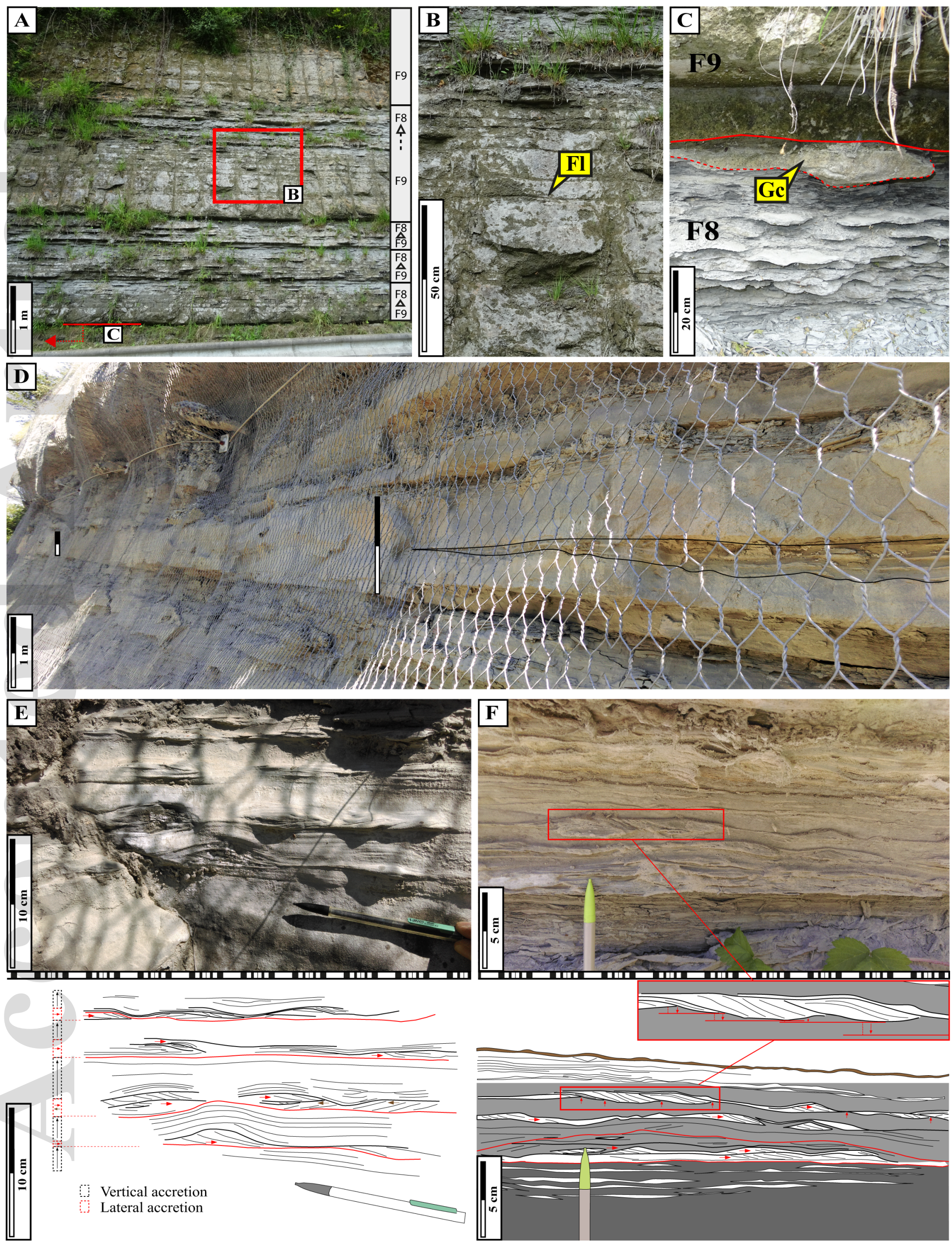

Vertical accretion

Lateral accretion

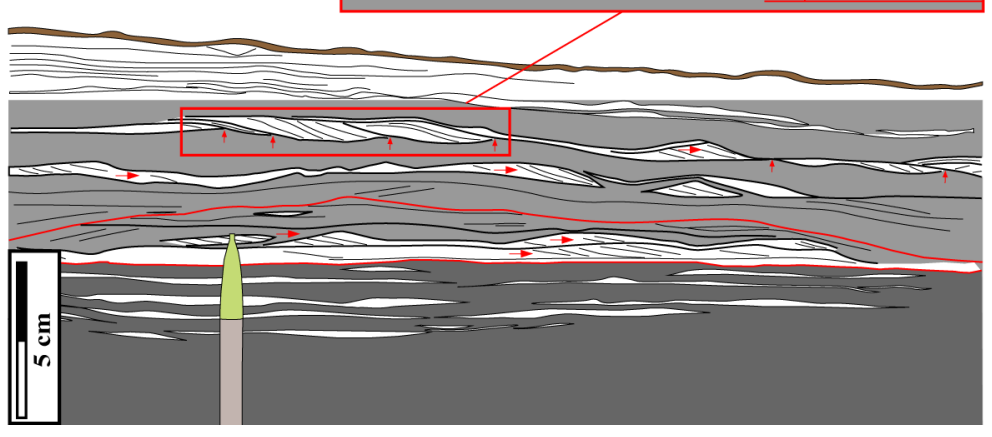



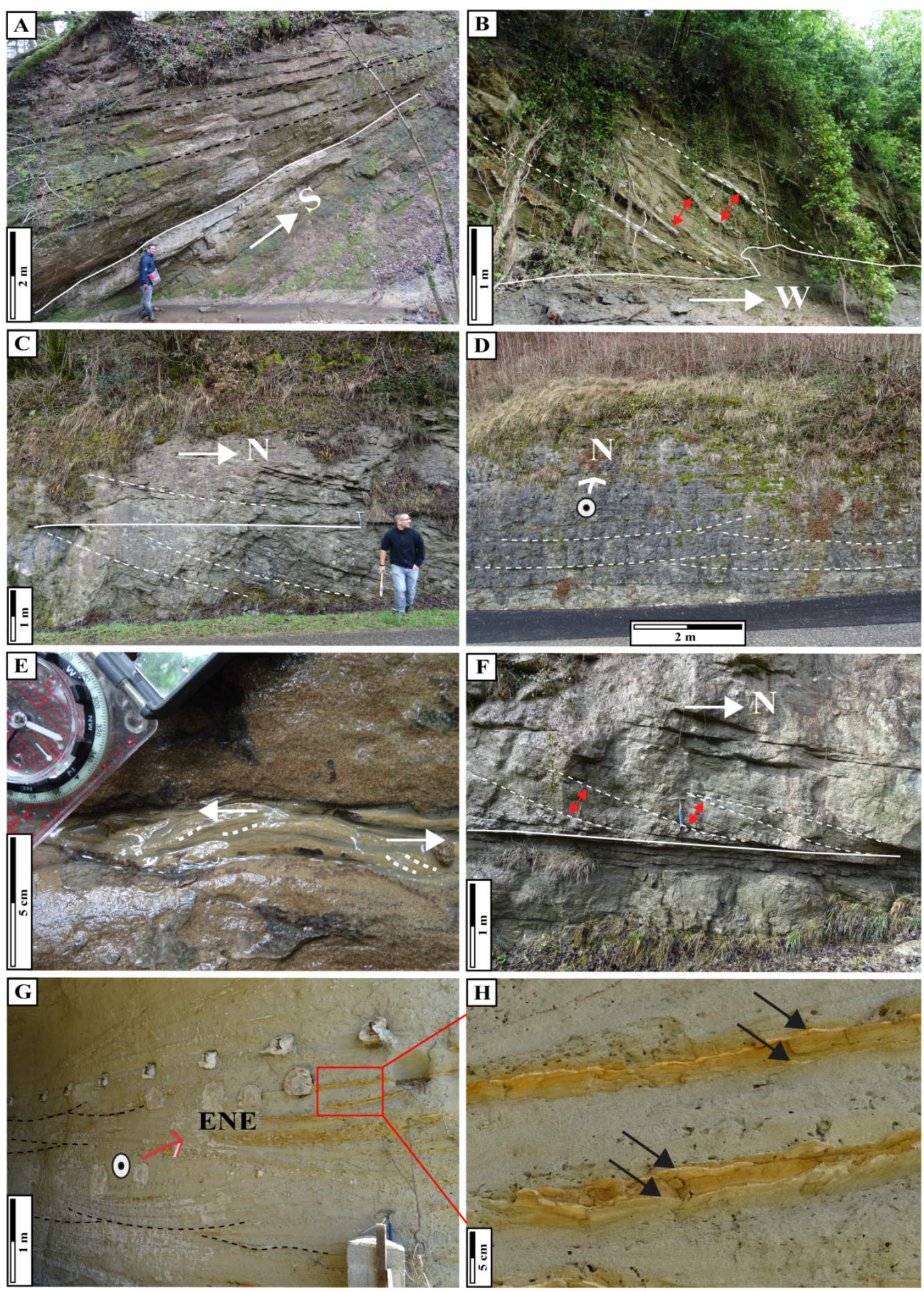

sed_12708_f6a.tif

This article is protected by copyright. All rights reserved 

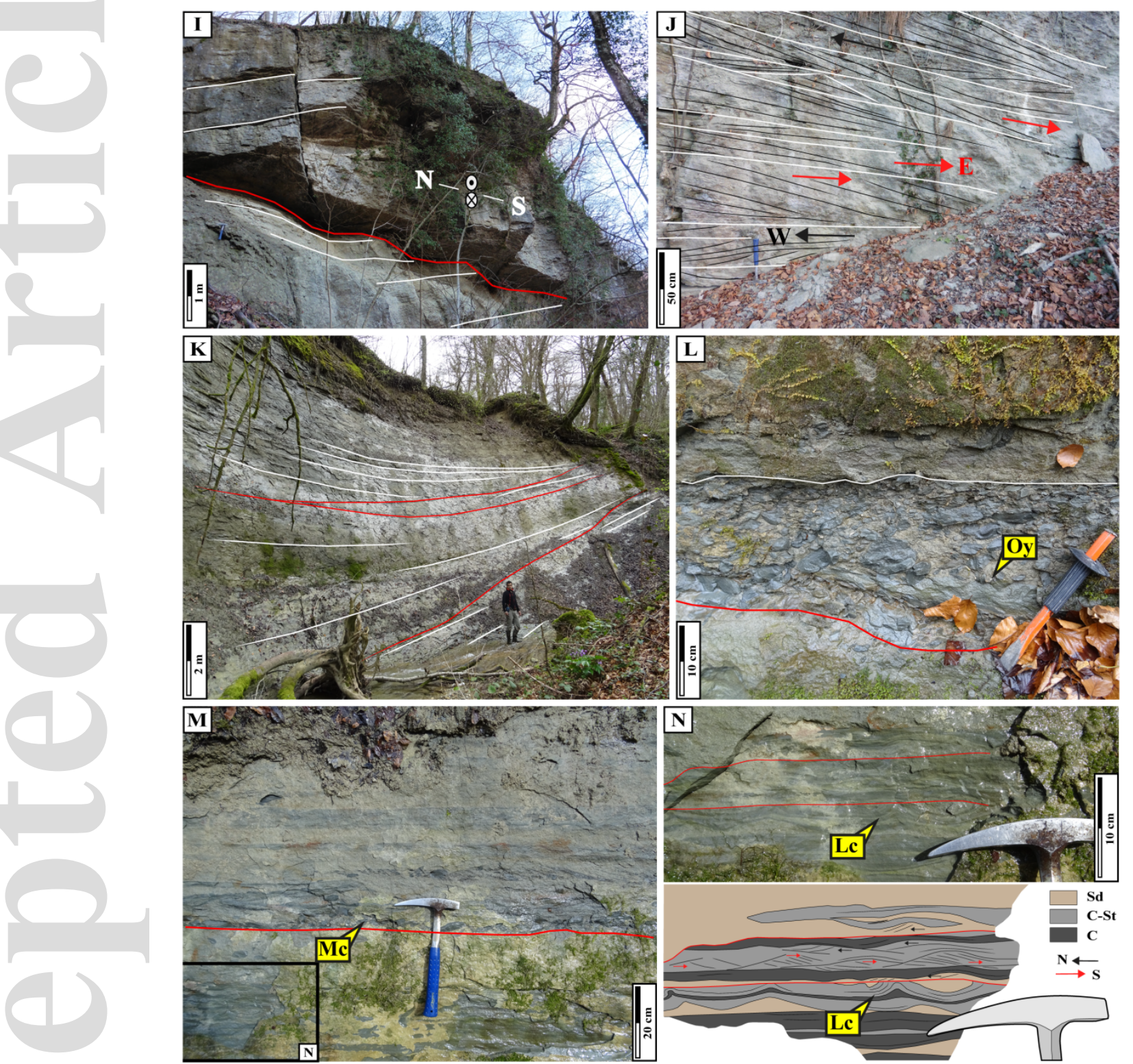

sed_12708_f6b.tif

This article is protected by copyright. All rights reserved 

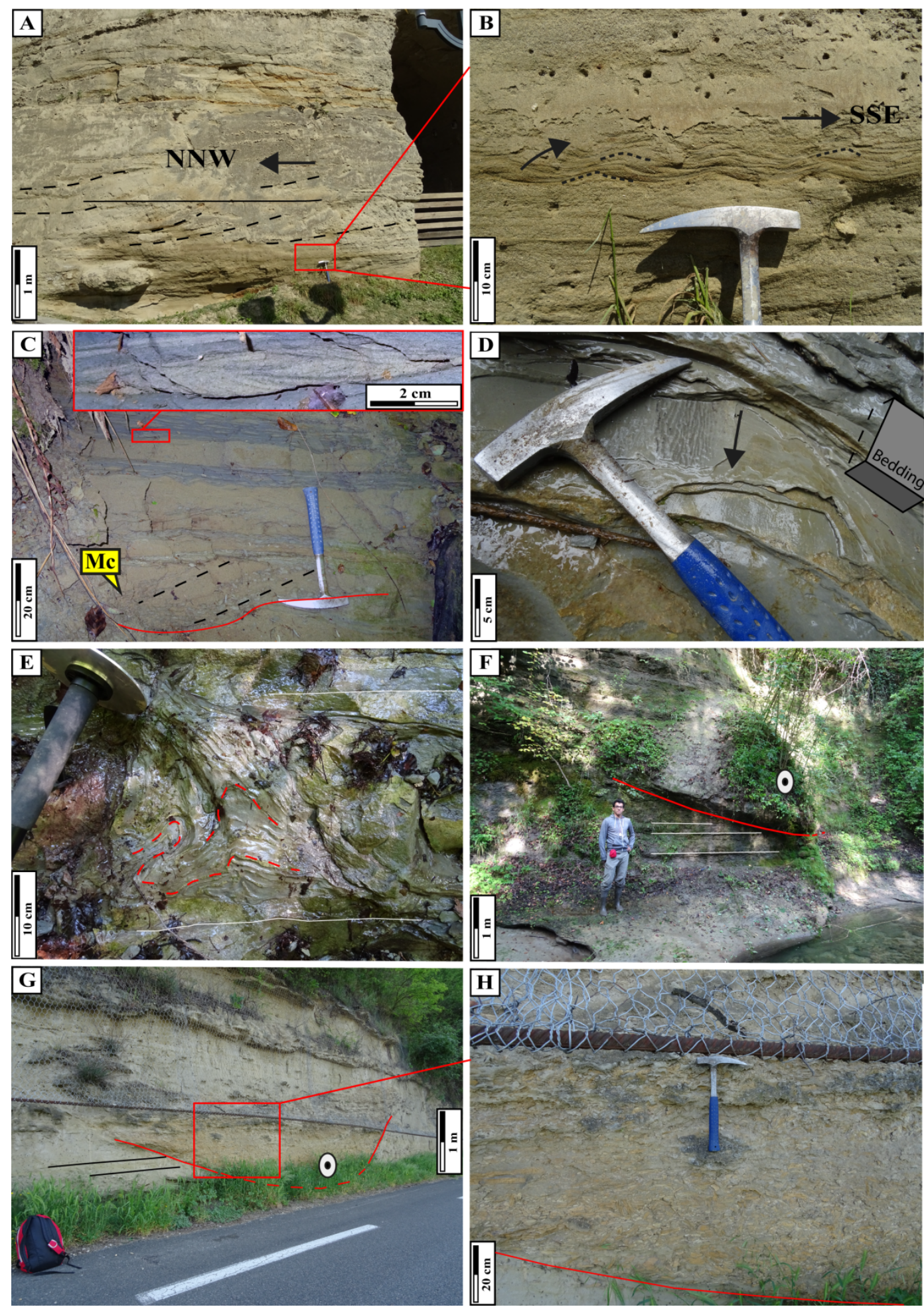

sed_12708_f7.tif

This article is protected by copyright. All rights reserved 

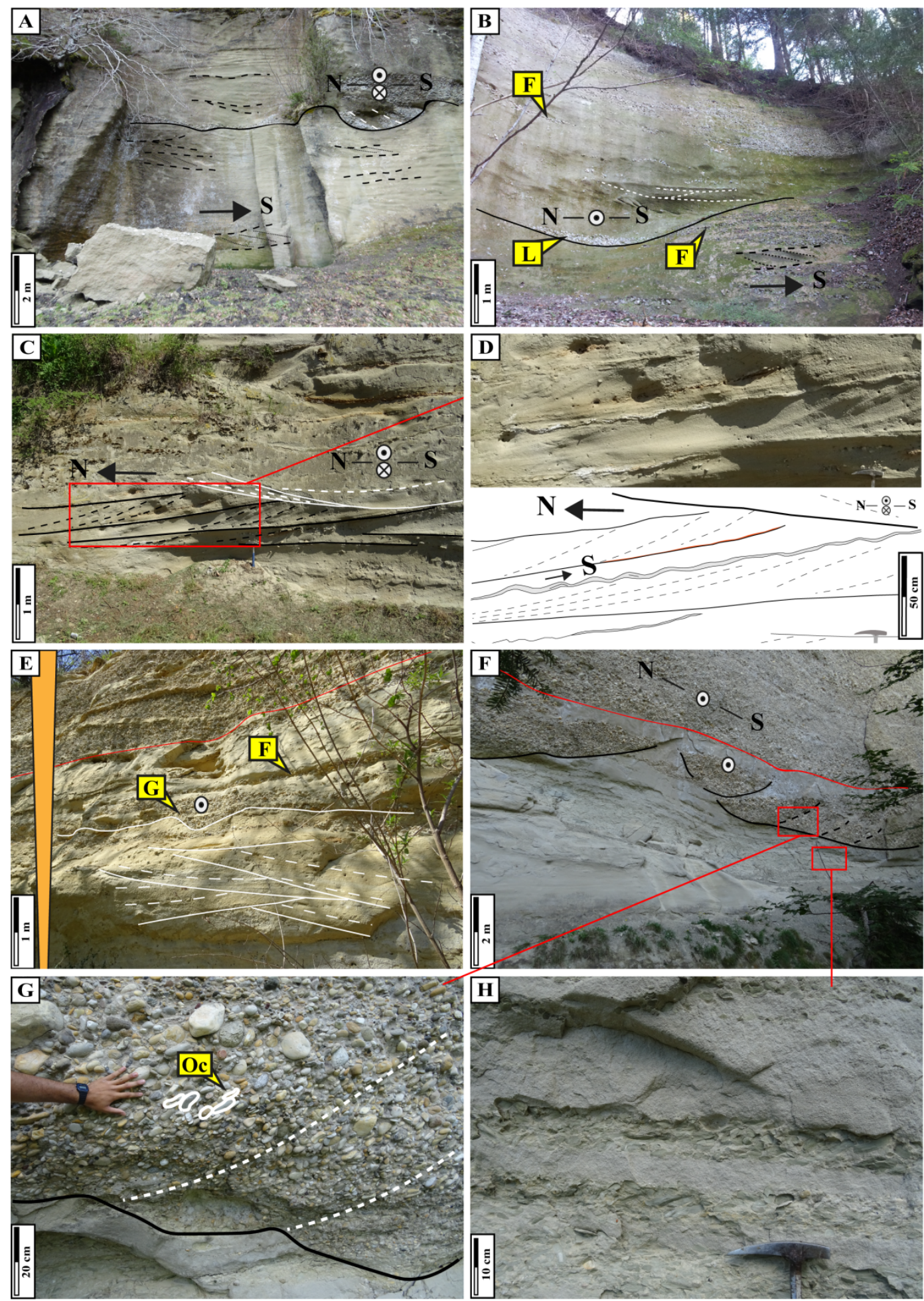

sed_12708_f8.tif

This article is protected by copyright. All rights reserved 


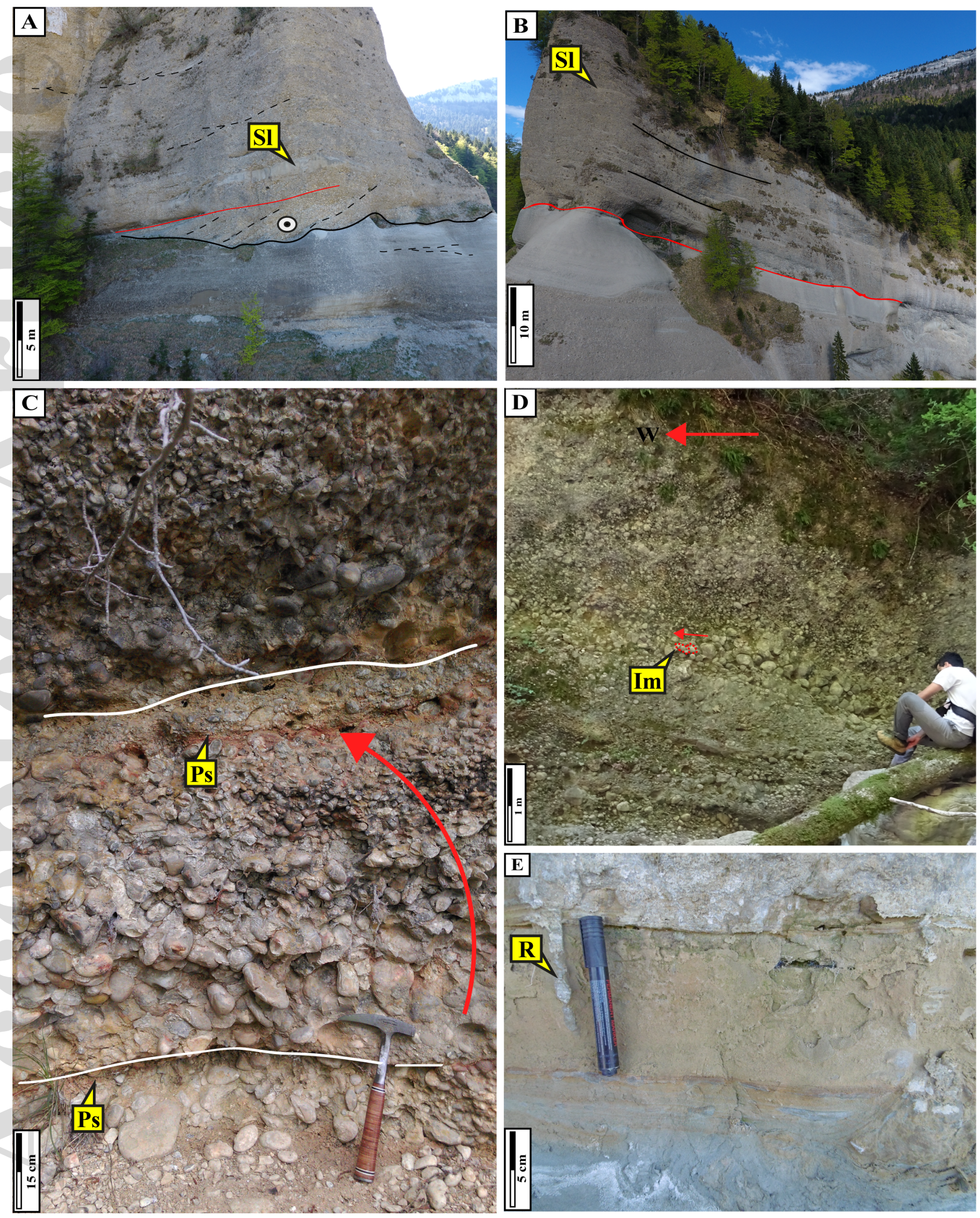

sed_12708_f9.tif

This article is protected by copyright. All rights reserved 

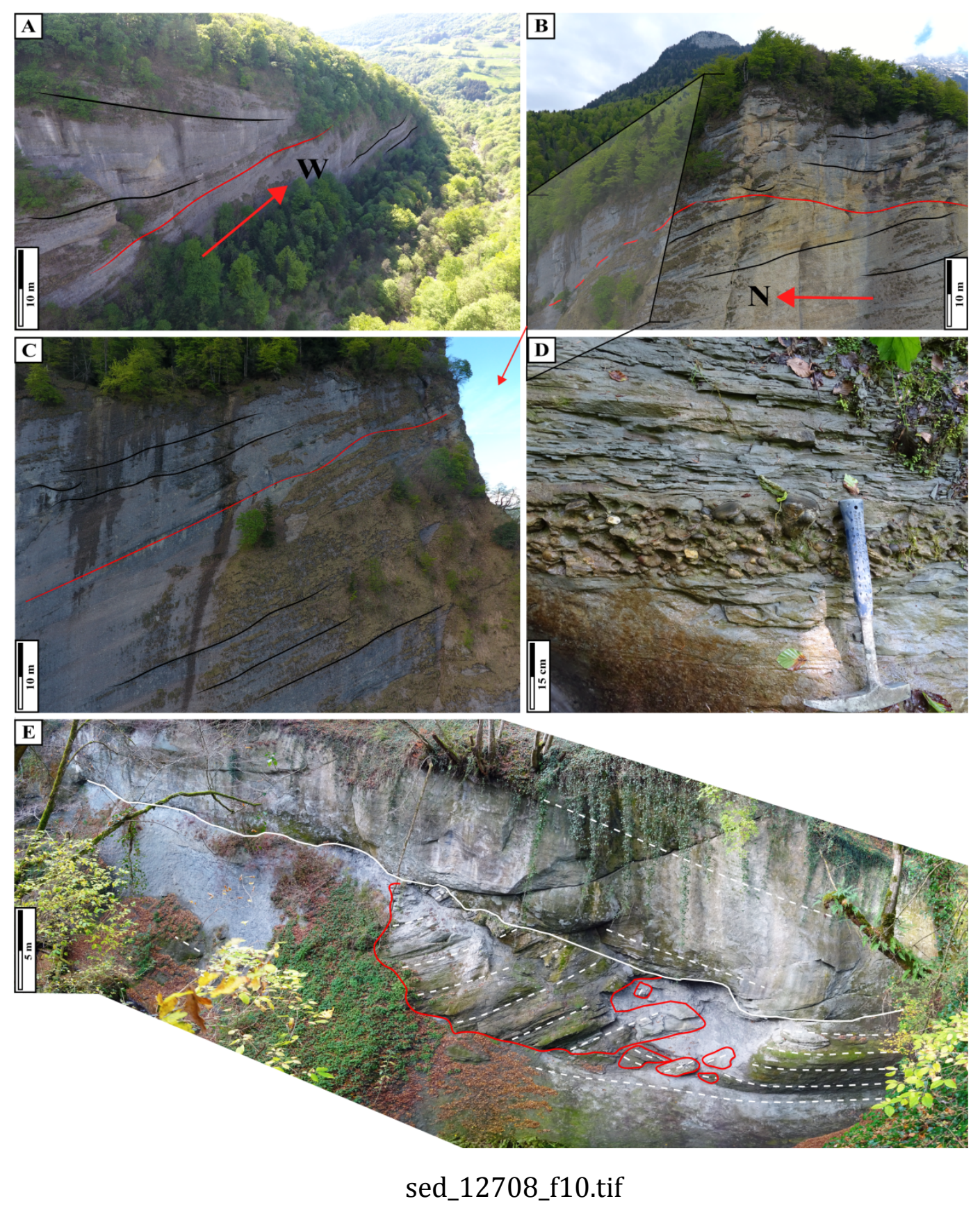

This article is protected by copyright. All rights reserved 


\begin{tabular}{|c|c|c|c|c|}
\hline 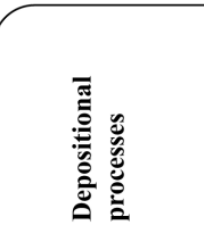 & 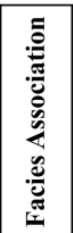 & 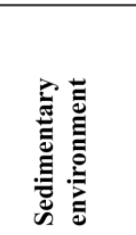 & Facies & Figures \\
\hline \multirow{6}{*}{$\begin{array}{c}\text { Wave } \\
\text { Dominated } \\
\text { (W) }\end{array}$} & \multirow{2}{*}{ FA1 } & \multirow{2}{*}{ Offshore } & F1 - Blue Marls & Fig.4A, B \\
\hline & & & F2 - Bioturbated silts & Fig.2A \\
\hline & FA2 & $\begin{array}{l}\text { Offshore } \\
\text { transition }\end{array}$ & $\begin{array}{l}\text { F3 - Bioturbated silts and } \\
\text { sandstones with HCS }\end{array}$ & Fig.2B \\
\hline & FA3 & Shoreface & $\begin{array}{l}\text { F4 - Amalgamated oscillation } \\
\text { structures }\end{array}$ & Fig.2C, D \\
\hline & \multirow{2}{*}{ FA4 } & \multirow{2}{*}{ Foreshore } & F5 - Planar lamination & Fig.3C, E, H \\
\hline & & & F6 - Beach berm & Fig.3B, C, D, J \\
\hline \multirow{4}{*}{$\begin{array}{c}\text { Mixed } \\
\text { Wave-Tide } \\
\text { (WT) }\end{array}$} & \multirow{2}{*}{ FA5 } & \multirow{2}{*}{$\begin{array}{l}\text { Open coast } \\
\text { subtidal }\end{array}$} & F7 - Lenticular bedding & Fig.4C, D, E, F \\
\hline & & & F8 - Wavy bedding & Fig.4G, $\mathrm{H}$ \\
\hline & \multirow{2}{*}{ FA6 } & \multirow{2}{*}{$\begin{array}{l}\text { Open coast } \\
\text { intertidal }\end{array}$} & F9 - Flaser bedding & Fig.5A, B \\
\hline & & & F10 - Ridges \& Runnels & Fig. $5 C, D, E$ \\
\hline \multirow{7}{*}{$\begin{array}{c}\text { Tide } \\
\text { Dominated } \\
\text { (T) }\end{array}$} & \multirow{4}{*}{ FA7 } & \multirow{4}{*}{ Subtidal } & F11 - Large scale tidal dunes & Fig. $6 \mathrm{~A}, \mathrm{~B}, \mathrm{C}$ \\
\hline & & & F12 - Medium scale tidal dunes & Fig.6D, E, F \\
\hline & & & F13 - Small scale tidal dunes & Fig.6G, $\mathrm{H}$ \\
\hline & & & F14 - Tidal channels & \\
\hline & \multirow{3}{*}{ FA8 } & \multirow{3}{*}{ Intertidal } & F15 - Sand flat & Fig.7A, B, G \\
\hline & & & F16-Mixed flat & Fig.7C, D, E, F \\
\hline & & & F17 - Tidal creeks & Fig.7F, G, H \\
\hline $\begin{array}{c}\text { Mixed } \\
\text { River-Tide (RT) }\end{array}$ & FA9 & $\begin{array}{c}\text { R-to-T } \\
\text { transition }\end{array}$ & F18 - River mouth & $\begin{array}{c}\text { Fig.8A, B, C } \\
\text { D, E, F }\end{array}$ \\
\hline \multirow{3}{*}{$\begin{array}{c}\text { River } \\
\text { Dominated (R) }\end{array}$} & FA10 & River & F19 - Braided-river system & $\begin{array}{l}\text { Fig. } 8 \mathrm{G}, \mathrm{H} \\
\text { Fig.9A, B }\end{array}$ \\
\hline & \multirow{2}{*}{ FA11 } & \multirow{2}{*}{ Gilbert D. } & F20 - Gilbert delta foresets & Fig.10A, B, C \\
\hline & & & F21 - Gilbert delta bottomsets & Fig.10D \\
\hline & \multirow{2}{*}{\multicolumn{2}{|c|}{ Subaerial exposure }} & F22 - Paleosoils & Fig.9A, C \\
\hline & & & F23 - Calcretes & \\
\hline & \multirow{2}{*}{\multicolumn{2}{|c|}{ Non-categorised }} & F24 - Transgressive lag & \\
\hline & & & F25 - Seismite & Fig.10E \\
\hline
\end{tabular}

\section{Depositional processes}

\section{Facies associations}

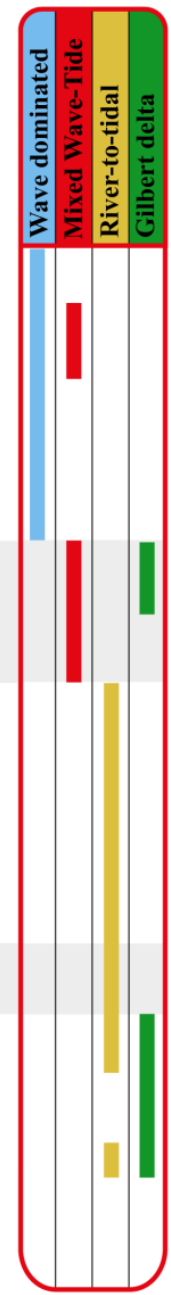

4 Depositional models

(see Fig.13)

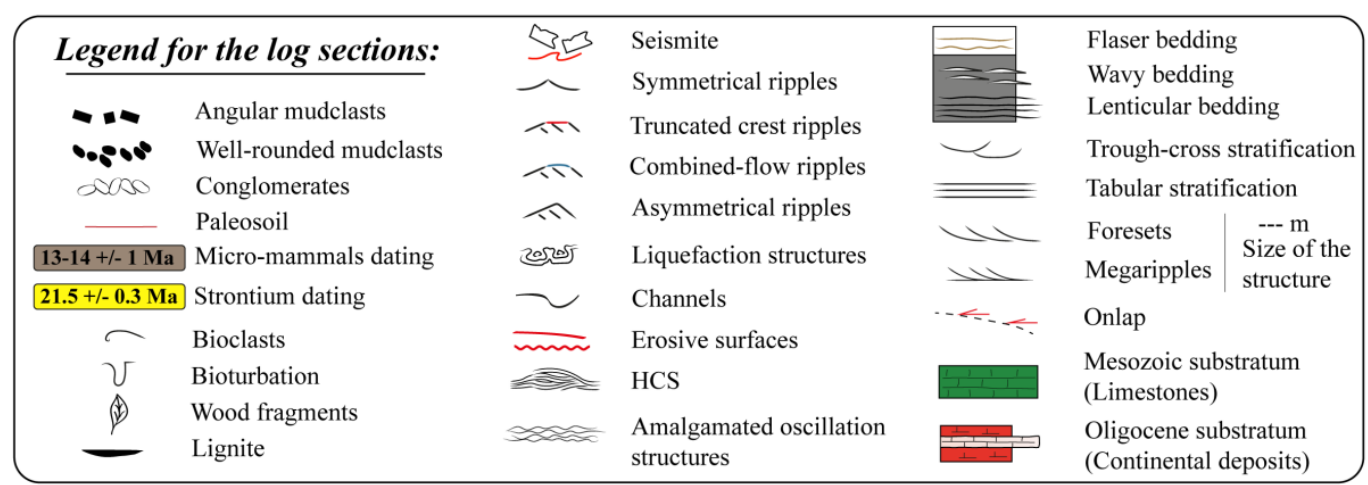

sed_12708_f11a.tif 


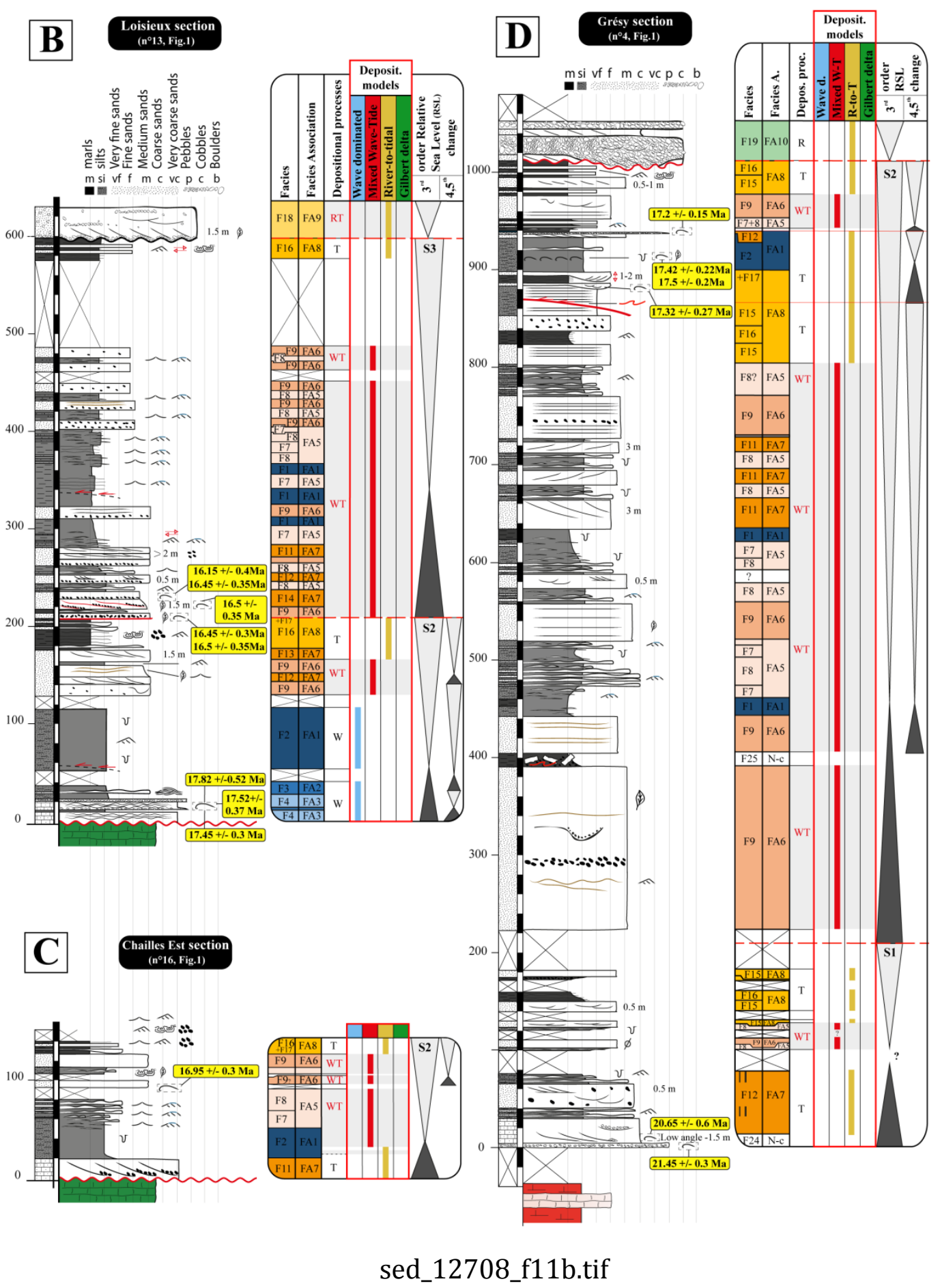

This article is protected by copyright. All rights reserved 


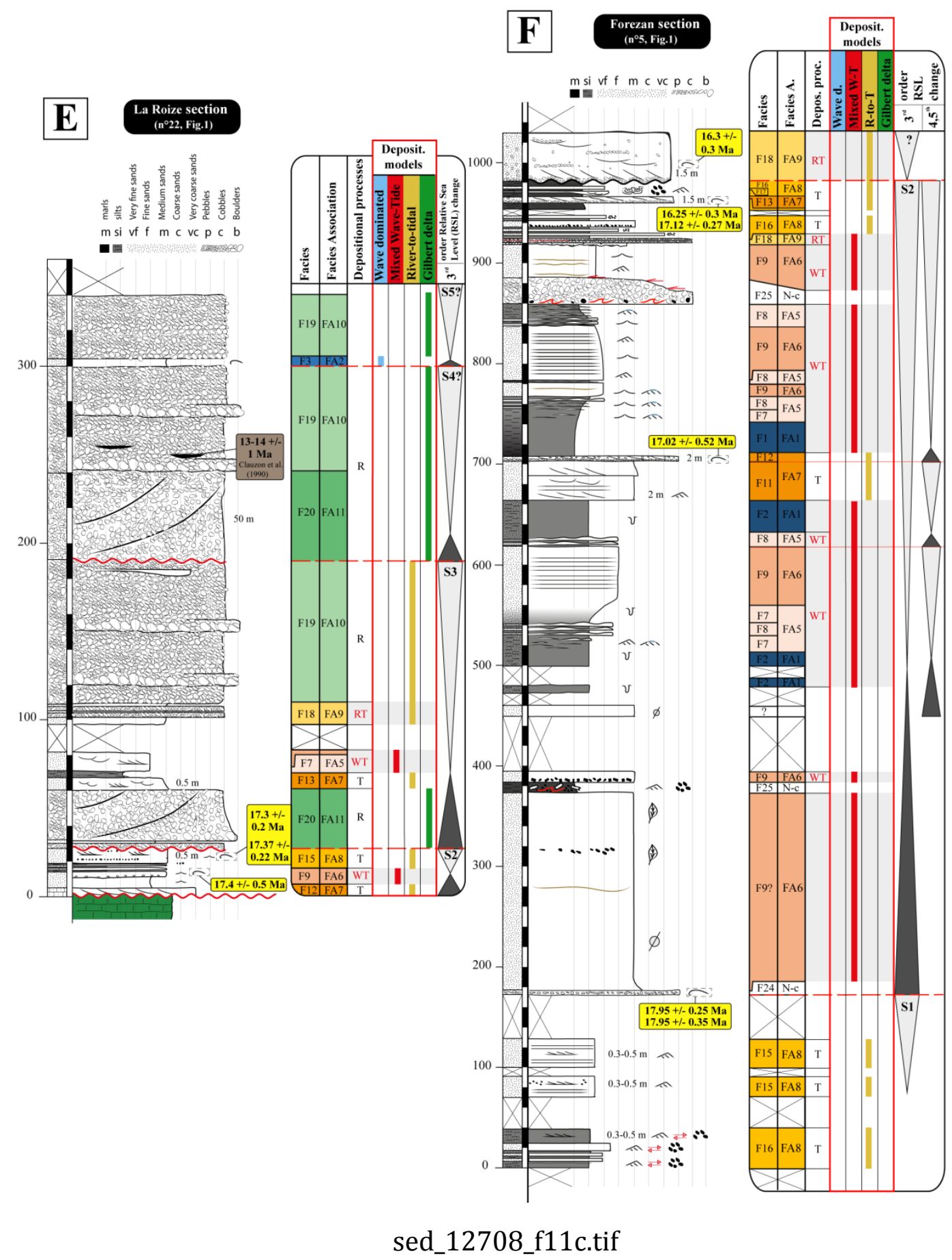

This article is protected by copyright. All rights reserved 


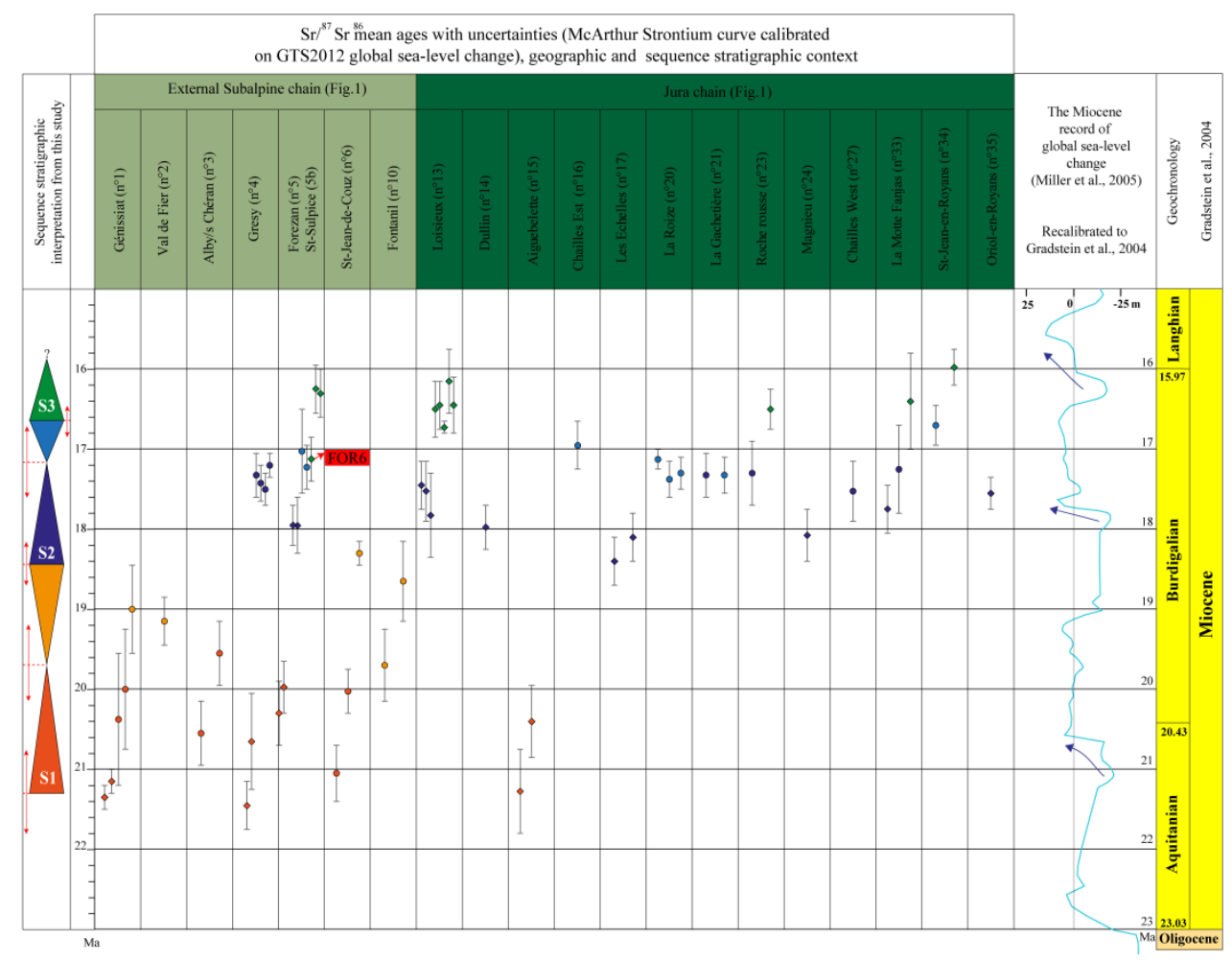

sed_12708_f12.tif 


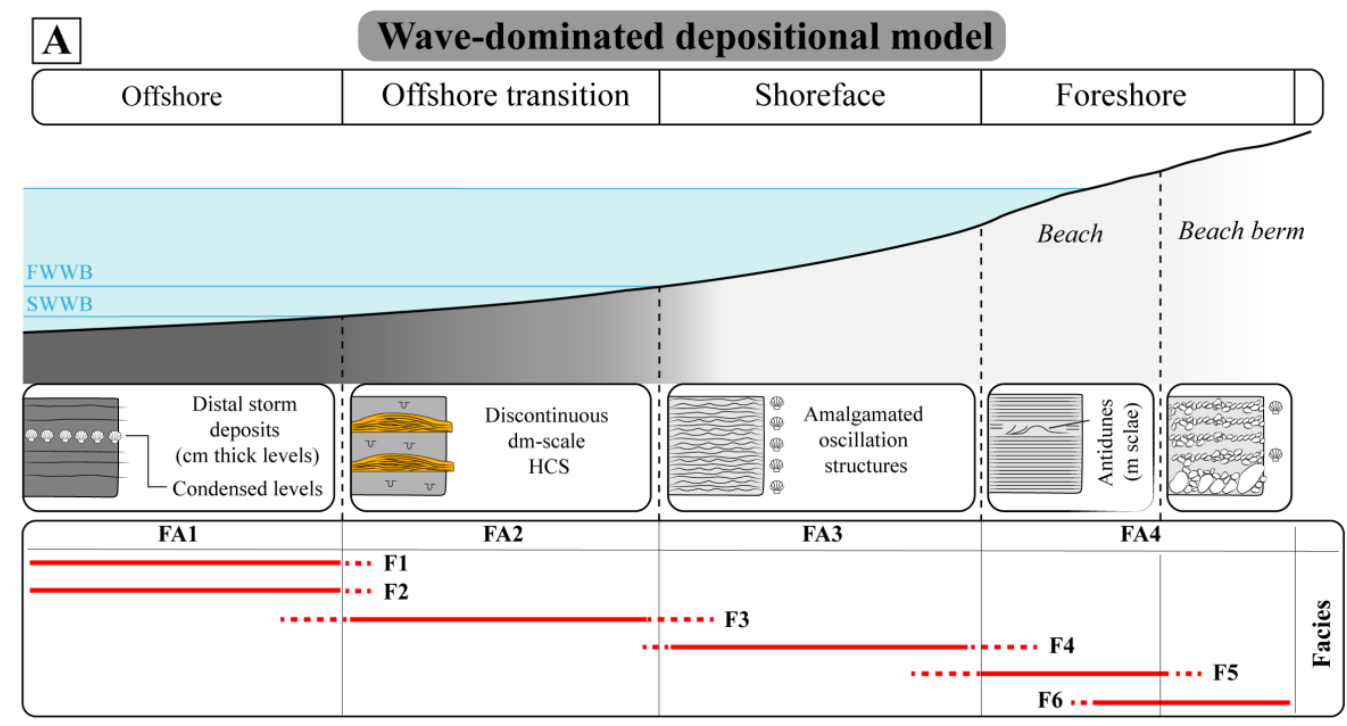

\begin{tabular}{|c|c|c|}
\hline B & \multicolumn{3}{c}{ Mixed Wave-Tide depositional model } \\
\hline Offshore & Open-coast subtidal & Open-coast intertidal \\
\hline
\end{tabular}

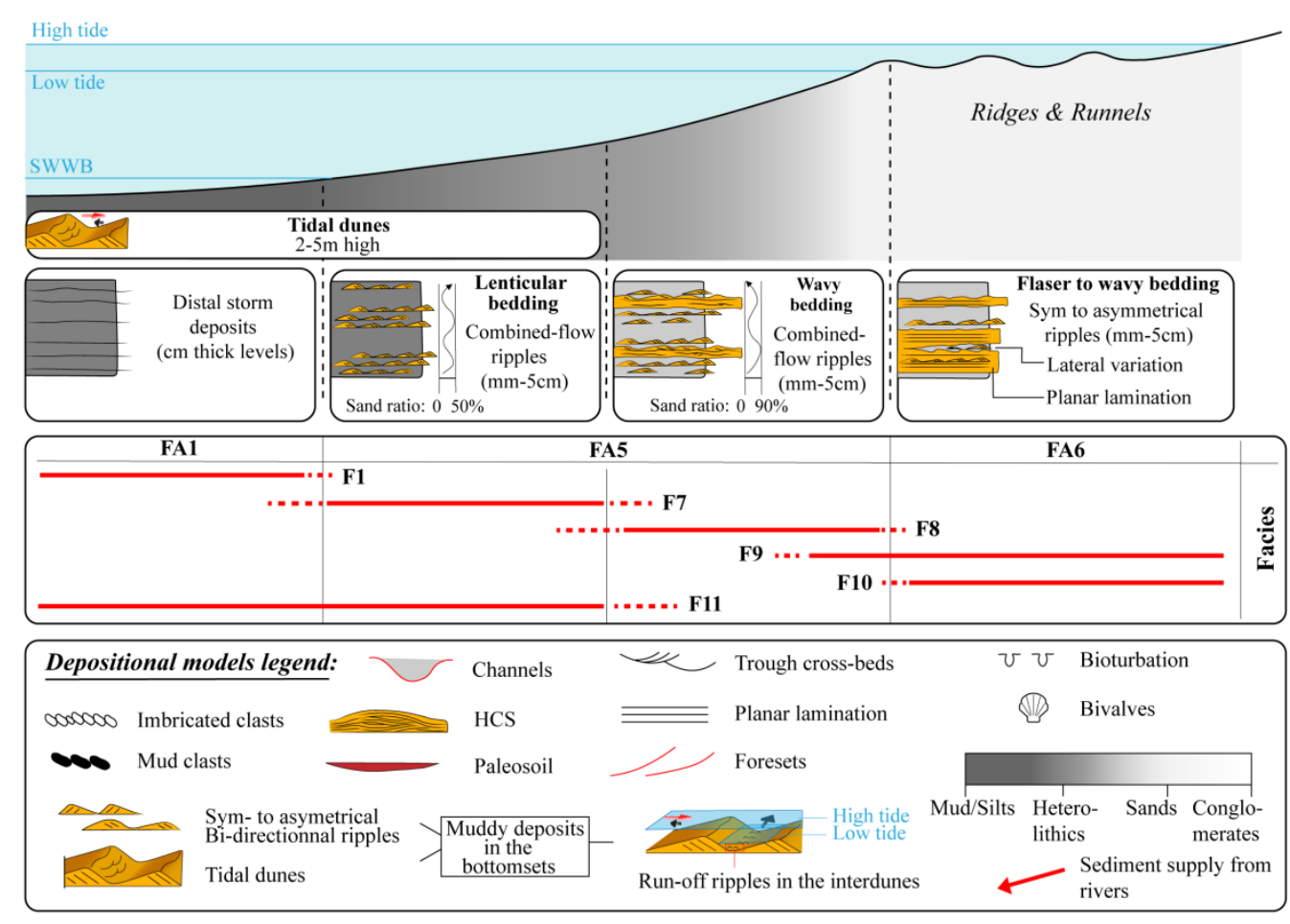

sed_12708_f13a.tif 
C

River-to-Tide depositional model

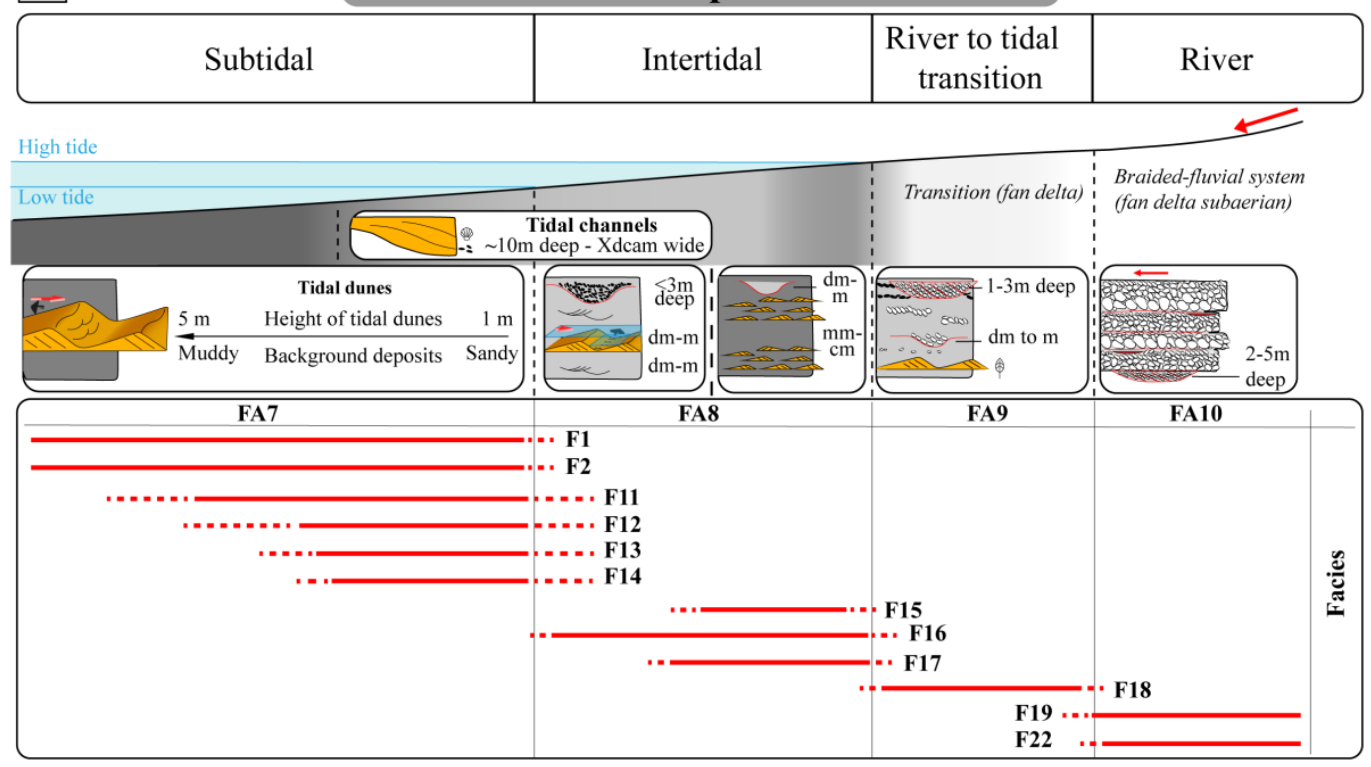

D River-dominated depositional model

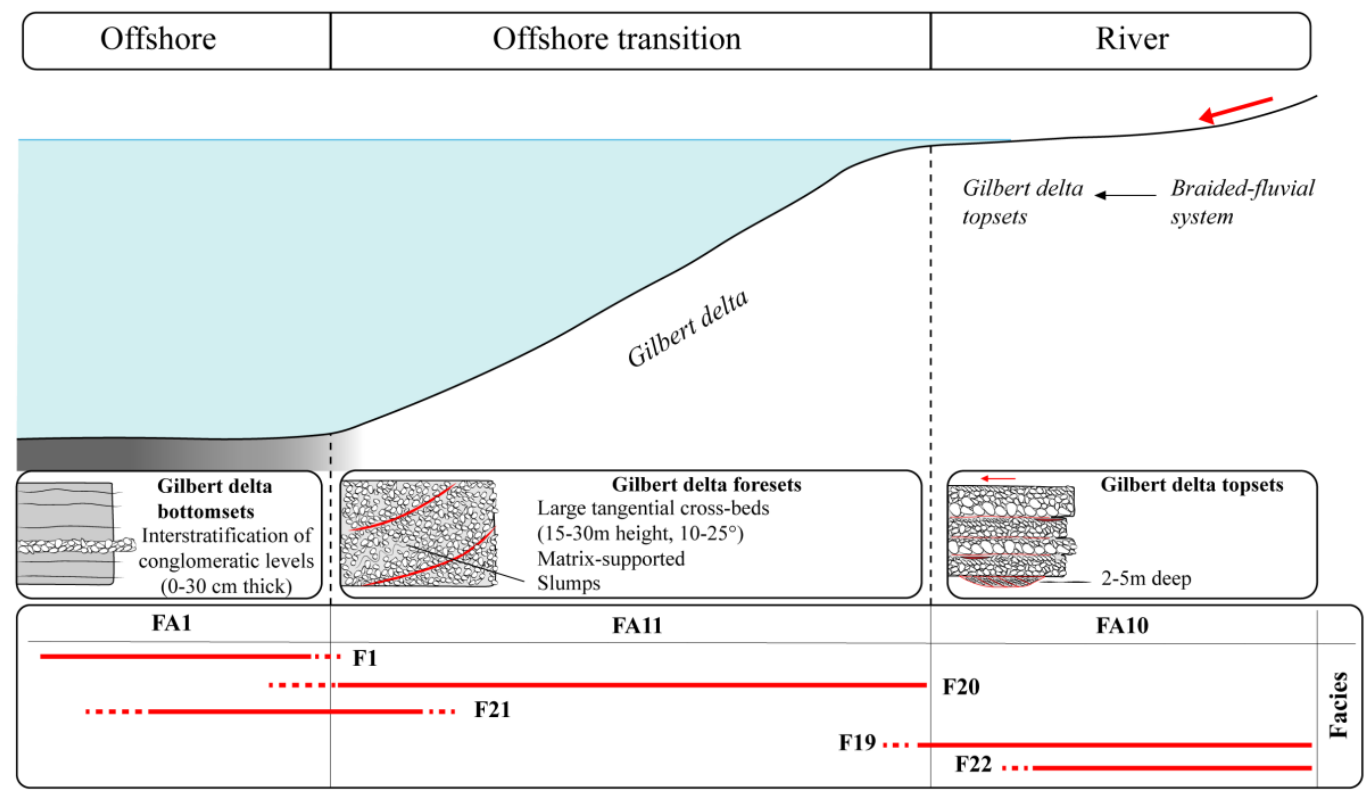

sed_12708_f13b.tif 


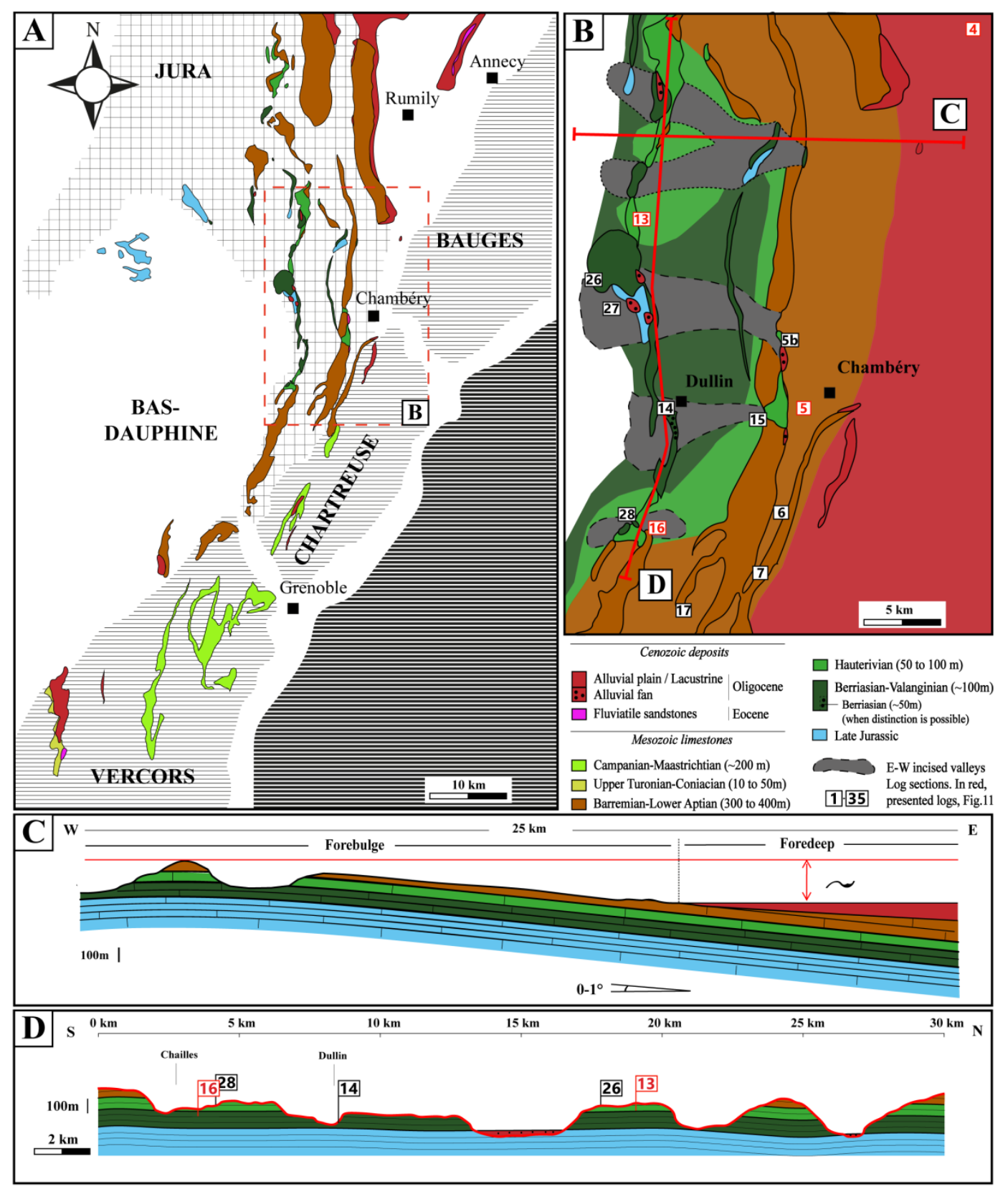

sed_12708_f14.tif

This article is protected by copyright. All rights reserved 


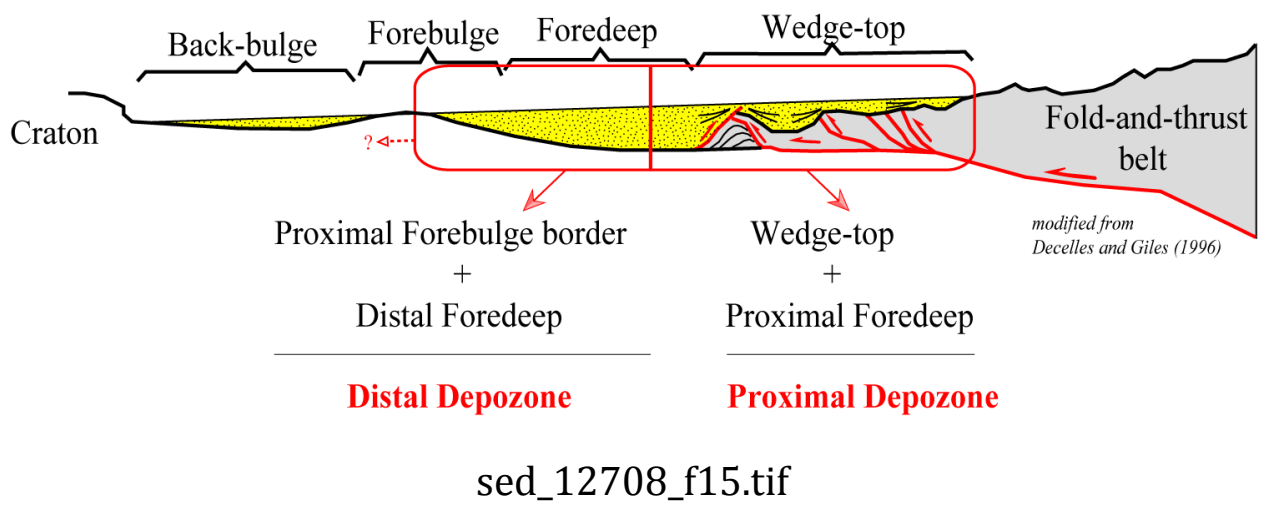

This article is protected by copyright. All rights reserved 

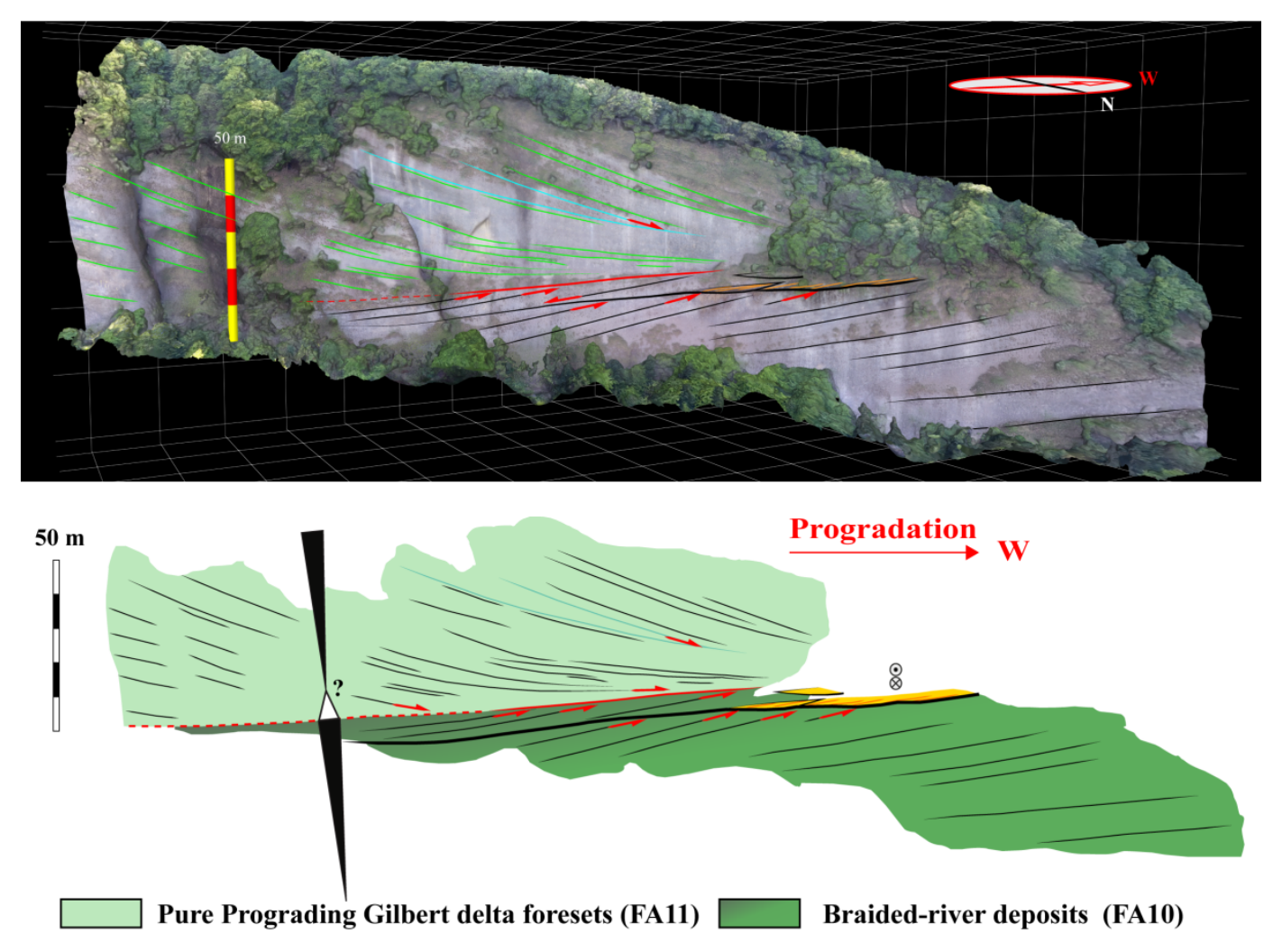

sed_12708_f16.tif 


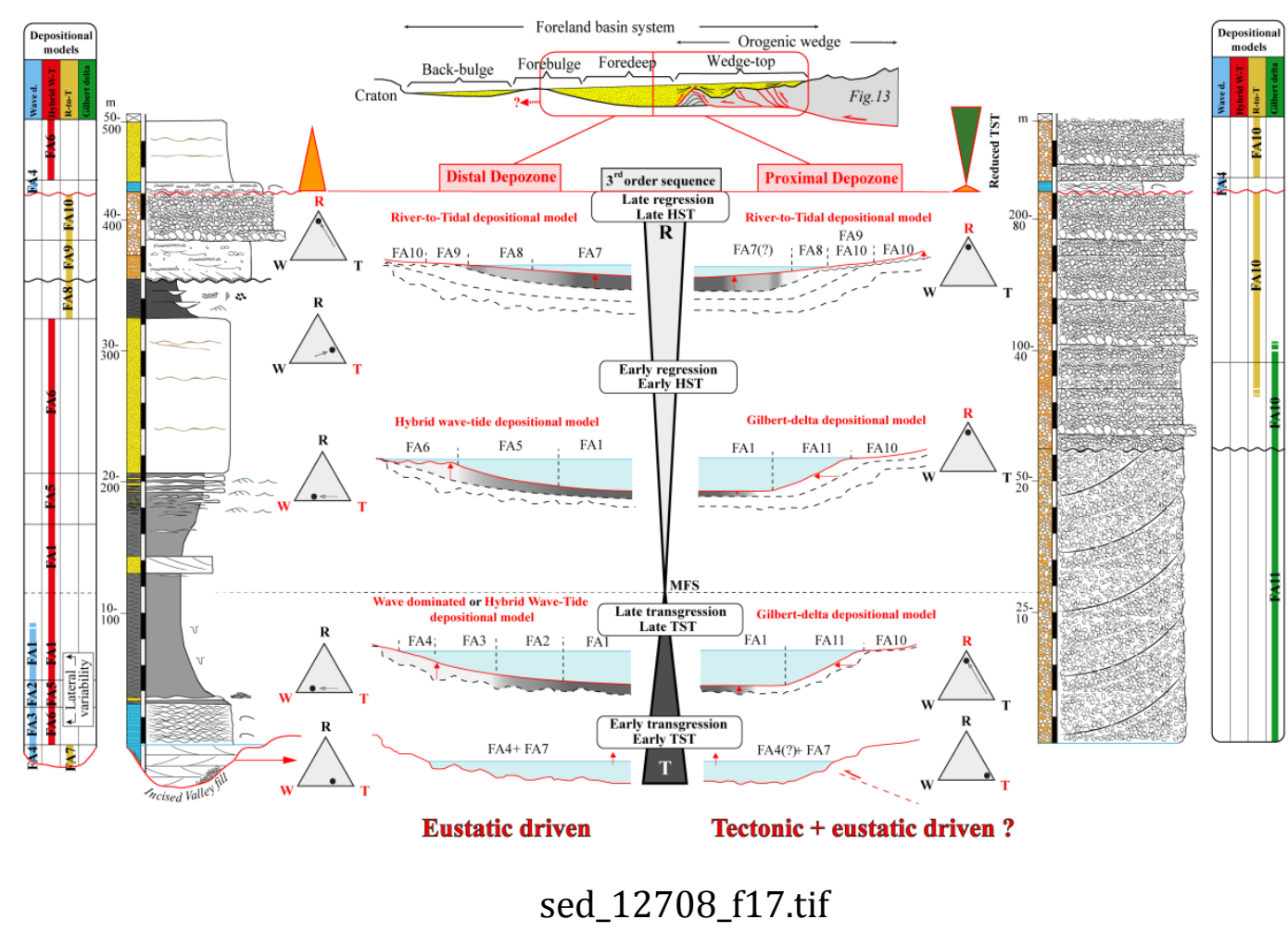

This article is protected by copyright. All rights reserved 


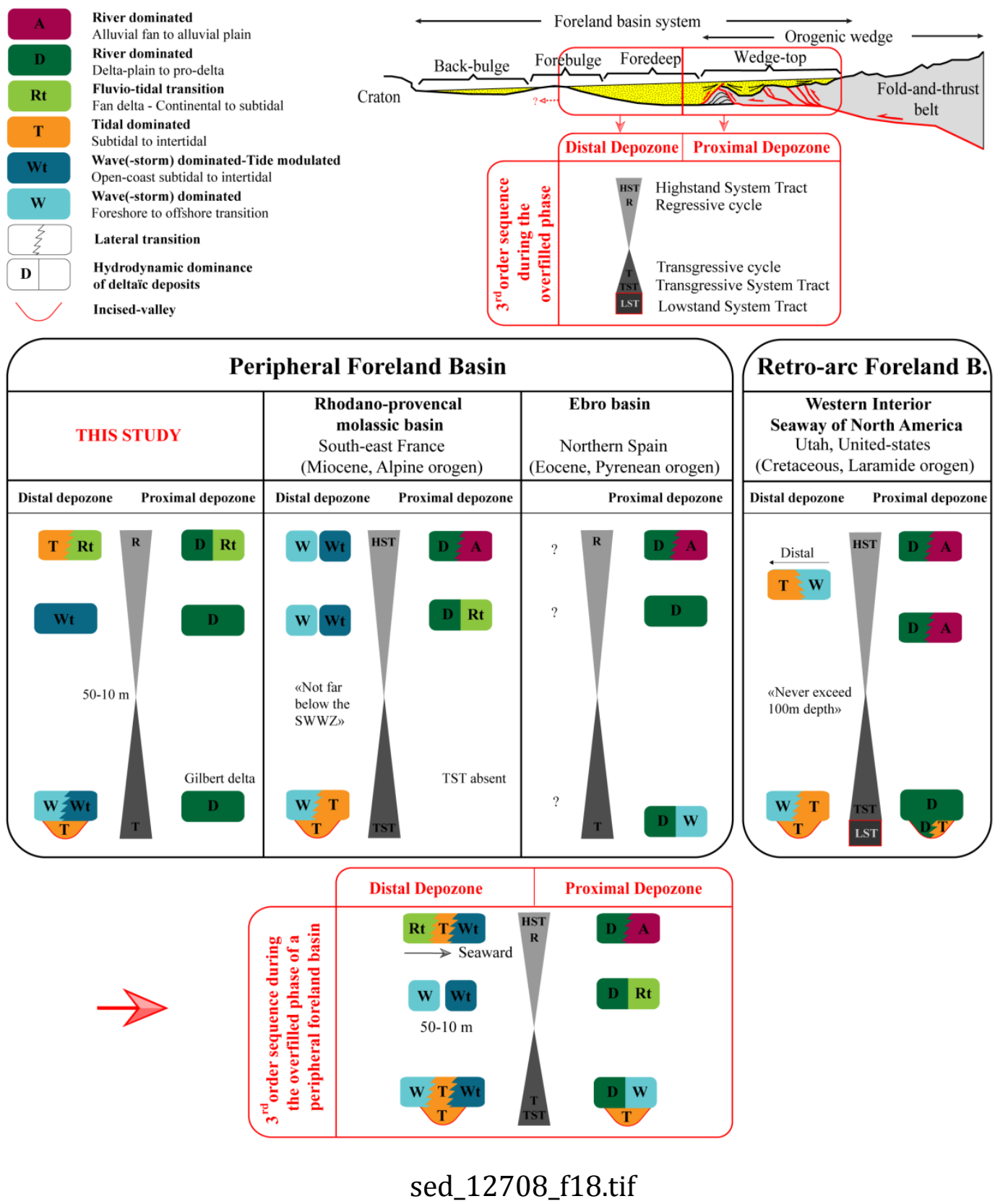

This article is protected by copyright. All rights reserved 